\title{
Better to stay apart: asset commonality, bipartite network centrality, and investment strategies
}

\author{
Andrea Flori* $\quad$ Fabrizio Lillo ${ }^{\dagger \ddagger} \quad$ Fabio Pammolli $\$$ \\ Alessandro Speltall
}

\begin{abstract}
By exploiting a bipartite network representation of the relationships between mutual funds and portfolio holdings, we propose an indicator that we derive from the analysis of the network, labelled the Average Commonality Coefficient (ACC), which measures how frequently the assets in the fund portfolio are present in the portfolios of the other funds of the market. This indicator reflects the investment behavior of funds' managers as a function of the popularity of the assets they held. We show that $A C C$ provides useful information to discriminate between funds investing in niche markets and those investing in more popular assets. More importantly, we find that $A C C$ is able to provide indication on the performance of the funds. In particular, we find that funds investing in less popular assets generally outperform those investing in more popular financial instruments, even when correcting for standard factors. Moreover, funds with a low $A C C$ have been less affected by the 2007-08 global financial crisis, likely because less exposed to fire sales spillovers.
\end{abstract}

Keywords: Mutual Funds; Bipartite Network; Alpha Persistence; Horse-race Portfolios; Average Commonality Coefficient

JEL codes: G11; G23; C02; C6

\footnotetext{
${ }^{*}$ Politecnico di Milano, Department of Management, Economics and Industrial Engineering; andrea.flori@polimi.it

${ }^{\dagger}$ Center for Analysis, Decisions, and Society (CADS) - Human Technopole, Milano, Italy; fabrizio.lillo@unibo.it

${ }^{\ddagger}$ Università di Bologna, Department of Mathematics, Bologna, Italy

${ }^{\S}$ Politecnico di Milano, Department of Management, Economics and Industrial Engineering; fabio.pammolli@polimi.it

『Center for Analysis, Decisions, and Society (CADS) - Human Technopole, Milano, Italy

"Center for Analysis, Decisions, and Society (CADS) - Human Technopole, Milano, Italy; alessandro.spelta@htechnopole.it
} 


\section{Introduction}

Evaluating funds' performances is of major interest for investors and market efficiency in general. Scholars have proposed several alternative models to both explain funds' performances and identify the main factors driving extra-performances. Starting from the traditional asset pricing model (namely, $C A P M$ ) which evaluates stocks performances in terms of how they are related to market returns, literature has introduced additional factors aimed at identifying peculiar risk contributors. Fama and French (1993) discussed a linear three-factors model where, in addition to market premium, two further factors were discussed to measure the historical excess returns of small vs. big caps and value vs. growth assets. Carhart (1997) enriched this framework by proposing a four-factors model where a momentum factor was defined to capture the role of winner minus loser assets in the market. More recently, Fama and French (2015) extended their three-factors model by adding profitability and investments factors, while Pástor and Stambaugh (2002) proposed a seven-factors model where three industry factors were added into the Carhart's model.

Market players are, however, likely to interpret information in different manners and actively manage their portfolios in the pursuit of generating performances which beat those expected from these factors. Skilled managers are those investors that should be more able to extract market signals and invest accordingly, thus generating positive extraperformances than less skilled investors. This, in turn, calls for the identification of systematic patterns in the way investors produce these extra-performances (namely, alphas in financial jargon), and whether they are persistent in time. Literature discussed to what extent these investors, that are considered as skilled players, are more likely to generate positive extra-performances and, eventually, beat other investors systematically. However, the predictability of funds performances has been questioned by empirical evidence and this fact motivated the growing literature on the relationship between managerial skills and the persistence of alphas (see e.g., Grinblatt and Titman (1992); Hendricks et al. (1993); Goetzmann and Ibbotson (1994); Brown and Goetzmann (1995); Elton et al. (1996); Bollen and Busse (2004); Barras et al. (2010); Busse et al. (2010); Fama and French (2010), among others).

One important determinant of alpha is clearly the ability to choose potentially prof- 
itable assets. It is likely that assets that are chosen by many other funds contribute to profitability in a way that is already explained by existing factors. For this reason in this paper we investigate whether the ability of picking assets which are not common to other funds brings information on managerial skills that is not embedded in traditional alpha measures.

In order to perform this analysis, we look at the system of funds and assets from a global point of view. The system can be seen as a bipartite network, where a link between a node in one set (funds) and a node in the other (assets) indicates a significant investment of the fund in the considered asset (see subsection 2.2 for a more formal definition). The similarity between two portfolios, termed the overlap ${ }^{1}$, is broadly defined as the fraction of common assets, while the commonality of an asset is the number of funds owning it. We can therefore define the Average Commonality Coefficient $(A C C)$ of a fund as the average commonality of the assets in its portfolio. Here we are thus interested in identifying not only those funds that diversify the most in terms of portfolio composition, but also we can recognize either those assets that are present in a huge share of funds or, alternatively, those that are held by few portfolios only. Hence, given the same level of diversification, as naively measured for instance by the number of assets in the portfolio, we can discriminate between those funds more prone to invest in niche markets (namely, in assets not present in many portfolios) and those that opt for common assets (namely, assets quite well-spread and popular among funds).

In particular, in this paper we focus on US equity mutual funds and we investigate managerial skills by focusing on the topological features of portfolio holdings ${ }^{2}$. Compositions may be, in fact, informative in signaling managerial preferences and changes in portfolio holdings can be exploited to reveal future funds' performances and managers' attitudes to risk. For instance, during market uncertainty, such as the crash of mid2007, investors allocated a growing portion of their portfolios to safer assets (see e.g., Kacperczyk and Schnabl (2010); Rösch and Kaserer (2013); Bethke et al. (2017) among others), corroborating a flight to quality selection of assets at portfolio level that might

\footnotetext{
${ }^{1}$ Portfolio overlaps are receiving increasing attention, especially in the literature of systemic risk due to fire sales spillover. See, for example, Caccioli et al. (2014); Greenwood et al. (2015); Corsi et al. (2016); Di Gangi et al. (2018).

${ }^{2}$ In the paper the terms constituents and assets, or holdings and compositions are considered interchangeable.
} 
have impacted on the overall similarity across funds and possibly to the effective extent of diversification in the market.

This work relates the extra-performance of each fund to the level of similarity with the rest of the system, where the latter combines both how the fund manager diversifies the portfolio and how the assets he or she selects are also selected by many other fund managers. In this regards, we do not rely on a typical indicator of diversification, e.g. the level of concentration of assets under management in the fund, but we apply a novel measure (the $A C C$ indicator) which embeds also the popularity of the assets present in the portfolio. This measure is related to a well-diffused toolbox of indicators developed in economic complexity by Hidalgo et al. (2007); Hidalgo and Hausmann (2009) to assess the topological structure of an economic system, such as the degree of diversification and the extent of specialization of each agent operating in that system. The economic-complexity index (ECI) developed by Hidalgo and Hausmann has been exploited to predict the future economic growth of a country by looking at diversity and sophistication of the products such country exports. Essential to the notion of economic complexity are analyses of the interconnected patterns of countries' trade exports in the global "product space". In this article, we start from these concepts and we investigate how funds move in the "portfolio constituents space". The essential insight is that constituents selected by a fund represent a proxy measure for the managerial "capabilities" of the manager.

This approach is, in part, in line with Cohen et al. (2005), who already recognized that similarity among portfolio holdings can provide useful information for performance predictability that is usually not included in alpha measures. In particular, their approach maps similarity across managers by measuring the quality of the assets held in their portfolio according to a weighting scheme that is based on the average alpha of the managers that invest in these assets. Here, by contrast, we attempt to gauge a different perspective of portfolio diversification which basically takes into account also the choice made by managers to pick niche vs. popular assets in the pursuit of positive alpha. In the following we show, that $A C C$ is weakly correlated with the one of Cohen et al. (2005), and that gives different and often better predictions of fund's performance.

We do not discuss why investors opt for more or less niche portfolios or, in our per- 
spective, for more or less peripheral assets. We present, instead, empirical evidence that managerial ability to generate extra-performances reflects the commonality properties of the assets under management and that this effect is in part affected by the impact of the crisis of mid-2007. Generally speaking, we observe that the $A C C$ dimension does not emerge simply as a proxy for managerial skills, but rather as a complementary criterion to alpha measures for building profitable investment strategies.

Literature already presented empirical evidence that the performances of actively managed funds relate to the way they concentrate their portfolios according to their informational advantages (see e.g., Coval and Moskowitz (1999); Kacperczyk et al. (2005); Cremers and Petajisto (2009)). Here we exploit the bipartite network topological structure to evaluate whether managers' extra-performances can be related to a different investment attitude towards asset commonality. This proposed indicator of manager's skill is exploited to describe alpha persistence in time and to interpret funds' extra-performances during the market turmoil of the recent global financial crisis. We find that, after controlling for three and five factors, those funds with more peripheral assets (namely, those funds with low values for $A C C$ ) are more prone to produce positive extra-performances than those investing in more popular assets. Portfolio strategies investing long in funds with low values of $A C C$ and short in those funds with high values for this topological indicator are then able to generate positive extra-performances even along an holding period characterized by a boom and burst cycle.

The rest of the paper is organized as follows: Section 2 will present the data set and the methodology applied to compute the $A C C$ indicator, discussing in particular how the network theory representation of the mutual funds perimeter can be exploited to extract information from portfolio holdings; Section 3 shows the results of our investment strategies involving the topological information under different time windows across the crisis; then, Section 4 discusses the main economic implications from the use of $A C C$ against alternative formulations of measures for managerial skills. Finally, Section 5 concludes. 


\section{Data and Methodology}

\section{$2.1 \quad$ Data}

Data are retrieved from the CRSP Survivor Bias-Free data set which collects historical holdings and performances for US open-ended mutual funds. CRSP database provides a mapping between portfolios and the funds investing on them. For instance there could be the case that a certain portfolio is held by multiple funds. In order to study portfolio overlapping across funds, we assign funds' gross returns ${ }^{3}$ to the corresponding portfolios proportionally to the funds total net asset values. By doing this, hereinafter terms funds and portfolios are used interchangeably. To study the relationships between funds and their constituents, we focus on those funds more involved in US equity instruments. This selection has been performed, in line with Schwarzkopf and Farmer (2010), by taking those funds with equity exposures corresponding to at least 80 per cent of the net asset value of the portfolio. Our data set encompasses portfolio holdings from 2004 to 2010 at a quarterly basis, while constituents' and funds' returns are mapped daily. The analyses are also conducted on two sub-samples, the pre-crisis period that ranges from 2004 to 2007 and the (post)-crisis period, from 2007 to 2010.

Starting from the raw data we have aggregated constituents using the Cusip ticker and we have added funds' fees so to obtain gross funds' returns. The overall data set includes more than 2,700 funds investing in about 15,000 constituents, whose averages are 1,882 and 10,274, respectively. Both the number of funds and of constituents present in the data set increase along time, from the year 2004 where we observe 1,113 funds and 5,018 constituents to the year 2010 where 2,345 funds and 14,334 constituents are collected in the sample. Despite the large number of entities recorded in the data set, not all funds and constituents are persistently present at all the releasing dates. At each quarter we consider in our analysis only to those funds (and corresponding constituents) that are present consecutively in two quarters.

Finally, our study relies on the alpha measures of managerial skills obtained from the three-factors and five-factors models (Fama and French (1993, 2015)), using time series re-

\footnotetext{
${ }^{3}$ Following Cohen et al. (2005) we include the annual expense ratio and 12(b)1 fees given by CRSP; we divide these amounts by 252 to get daily quota, and we add the resulting value to each daily net fund's return to obtain gross returns.
} 
trieved from the K. French data library (http://mba.tuck.dartmouth.edu/pages/faculty/ken.french/data

\subsection{Methodology}

Our data set can be easily interpreted as a dynamic bipartite network $H_{t}(F, C)$ in which nodes can be separated into two types, funds $(F)$ and constituents $(C)$, such that links only connect nodes in different partitions (for an example see Figure 1). In recent years, many economic and financial systems have been described and modeled in terms of bipartite networks (see e.g., Tumminello et al. (2011); Huang et al. (2013); Caccioli et al. (2014); Barucca and Lillo (2016)).

Figure 1: Example of the bipartite network for 100 funds and constituents. The figure represents the relationships between the first 100 funds and the first 100 constituents (in alphabetical order) for the last quarter of 2005. Notice the heterogeneity between the links connecting funds and constituents. Some constituents are very popular (held by the majority of the funds) while others are present in few portfolios only. Similarly, some funds invest in many assets while other funds concentrate their portfolios in few assets.

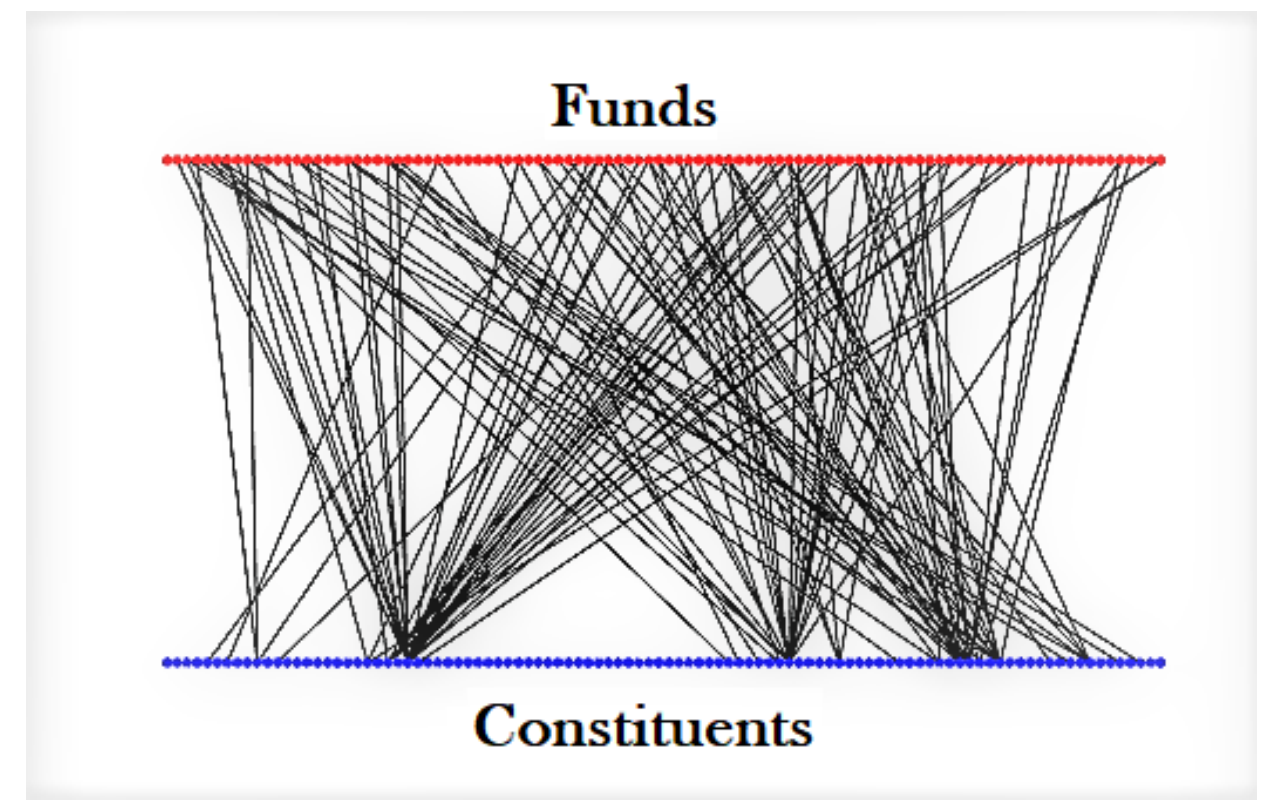

In order to focus on constituents that really define the behavior of each fund, a stringent measure of portfolio composition is needed. We say that a fund $F_{i}$ holds a relevant exposure to constituent $C_{j}$ whenever the ratio of the market value of constituent $C_{j}$ in the portfolio of fund $F_{i}$ over the average market value of constituent $C_{j}$ in the whole galaxy of funds is greater than a certain threshold $x$. This definition is the analogous of the Revealed Comparative Advantage (RCA) proposed by Balassa (1965) and previously applied in the trade networks by Hidalgo et al. (2007); Hidalgo and Hausmann (2009).

For each quarter $t$ and fund $F_{i}$ we compute the relative holding $R H$ for constituent $C_{j}$ as follows: 


$$
R H_{t}\left(F_{i}, C_{j}\right)=\frac{H_{t}\left(F_{i}, C_{j}\right)}{\sum_{C_{j}} H_{t}\left(F_{i}, C_{j}\right)} / \frac{\sum_{F_{i}} H_{t}\left(F_{i}, C_{j}\right)}{\sum_{F_{i}} \sum_{C_{j}} H_{t}\left(F_{i}, C_{j}\right)}
$$

This helps us in defining the bipartite network $M_{t}\left(F_{i}, C_{j}\right)$ of funds' holdings at every quarter. We set $M_{t}\left(F_{i}, C_{j}\right)=1$ if the relative holding of funds $F_{i}$ with respect to the constituent $C_{j}$ at time $t$ is greater or equal then 1 , i.e. $R H_{t}\left(F_{i}, C_{j}\right) \geq 1$. This measure informs whether a fund's holding of a constituent is larger or smaller than the average holding of the entire galaxy of funds. We perform also some robustness analysis by letting the threshold to vary from 0 to 100 . Figure 2 indeed shows the network density, i.e. the portion of the potential connections in a network that are actual connections as long as the threshold varies.

Figure 2: Network Density for different threshold values. Semi-Log plot of the percentage of links present for different threshold values. The dashed gray line identifies $R H_{t}\left(F_{i} . C_{j}\right)=1$ that represents the market average. Each line stands for one particular quarter.

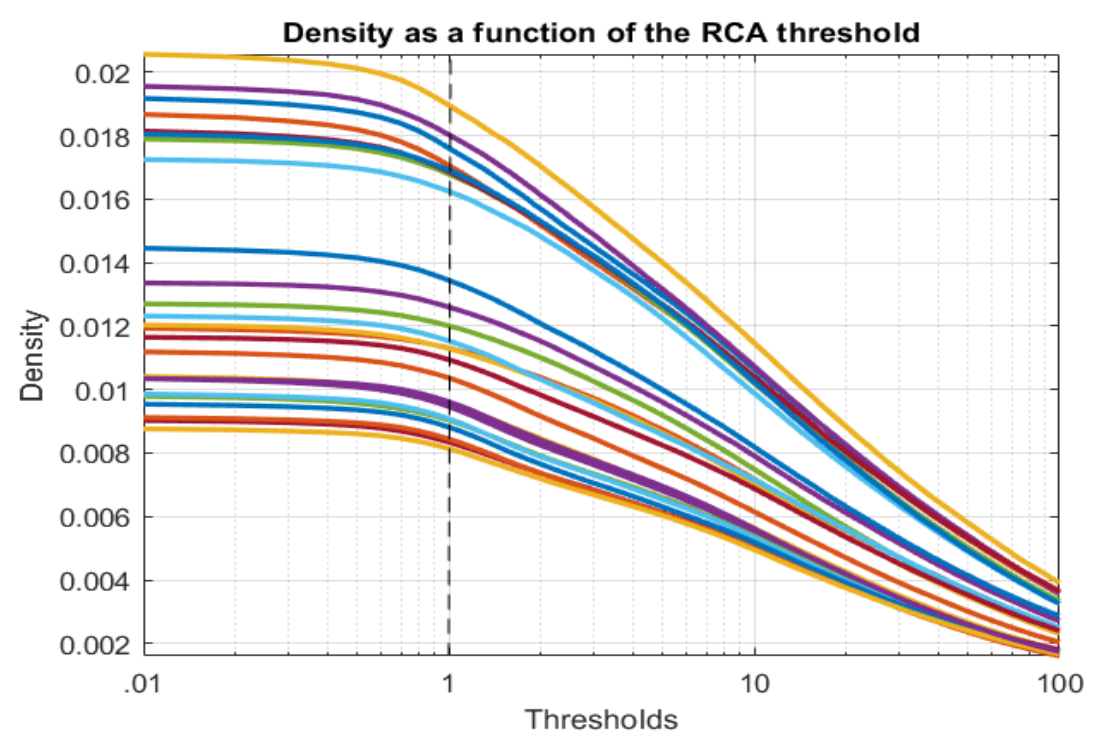

As in Hidalgo et al. (2007) and Hidalgo and Hausmann (2009), we now consider the temporal bipartite network $M_{t}$ described by the adjacency matrix $M_{t}\left(F_{i}, C_{j}\right)$, where $M_{t}\left(F_{i}, C_{j}\right)=1$ if fund $F_{i}$ is connected to constituent $C_{j}$ and zero otherwise. Dropping the temporal suffix $t$, the method of reflections ${ }^{4}$ consists of computing iteratively the average value of the previous-level properties of a node's neighbors and is defined as the set of

\footnotetext{
${ }^{4}$ There is a vivid debate on how to apply indicators of economic complexity in different economic fields (see e.g., Bahar et al. (2014); Gala et al. (2017); Hartmann et al. (2017); Desmarchelier et al. (2018)). Furthermore, recent publications have also proposed nonlinear versions of the algorithm to measure centrality in bipartite networks; the interested reader can refer e.g. to: Tacchella et al. (2012, 2013); Morrison et al. (2017); Alshamsi et al. (2018), among others.
} 
observables:

$$
\begin{aligned}
& k_{F_{i}, N}=\frac{1}{k_{F_{i}, 0}} \sum_{C_{j}} M\left(F_{i}, C_{j}\right) k_{C_{j}, N-1} \\
& k_{C_{j}, N}=\frac{1}{k_{C_{j}, 0}} \sum_{F_{i}} M\left(F_{i}, C_{j}\right) k_{F_{i}, N-1}
\end{aligned}
$$

for $N \geq 1$, with initial conditions given by the degree, or number of links, of funds and holding constituents:

$$
\begin{aligned}
k_{F_{i}, 0} & =\sum_{C_{j}} M\left(F_{i}, C_{j}\right) \\
k_{C_{j}, 0} & =\sum_{F_{i}} M\left(F_{i}, C_{j}\right)
\end{aligned}
$$

We can easily summarize the interpretation of the variables described by the method of reflections in economical terms. Indeed, $k_{F_{i}, 0}$ represents the number of constituents, i.e. the diversification of the fund holds ${ }^{5} . k_{C_{j}, 0}$ is the number of funds having constituent $C_{j}$ in their portfolio (i.e., the commonality property). Basically, if $k_{F_{i}, 0}$ is low it means that fund $F_{i}$ is very concentrated in few assets, while a high $k_{F_{i}, 0}$ represents a fund that diversifies its portfolio among many assets; by contrast, a low $k_{C_{j}, 0}$ means that asset $C_{j}$ is a niche asset held by few funds whereas a high value of $k_{C_{j}, 0}$ represents a popular asset present in many portfolios. In the economic complexity jargon this feature refers to the commonality property of the node in the network, which basically in this context indicates how the asset is popular/common ${ }^{6}$ among portfolio holdings.

Recursively, the variable $k_{F_{i}, 1}$ is the average commonality of constituents in the portfolio of fund $i$, while $k_{C_{j}, 1}$ represents the average diversification of the funds having constituent $C_{j}$ in their portfolio. Since we focus on funds' managers behavior in stock picking, we denote the $A C C$ indicator as $k_{F_{i}, 1}$. Thus, this measure differentiates among funds investing in niche assets versus those opting for more popular assets by looking at the average commonality of the constituents in the funds portfolios ${ }^{7}$. In the analysis we say

\footnotetext{
${ }^{5}$ To be precise, the quantity $k_{F_{i}, 0}$ represents the number of constituents held by a fund whose holding is greater than or equal to the share held on average by the other funds.

${ }^{6}$ Hence, the term commonality applied here is slightly different from the usage in other financial applications (see e.g., Flannery and James (1984); Allen et al. (2012); Namvar and Phillips (2013), among others).

${ }^{7}$ We have also applied higher order measures of commonality as, for instance, $k_{F_{i}, 2}$ to compute invest-
} 
that a fund belongs to the low percentile of the $A C C$ distribution if the assets in its portfolio have on average low values for commonality, while the opposite occurs if its assets are popular.

Table 1: Summary Statistics. Summary statistics of the reference quantities (Diversification, ACC and Returns) utilized throughout the paper divided into two sub-periods, namely 2004-07 and 2007-10. For each measure and for each sub-period, we report the minimum (min.), the maximum (max.), the average (mean) value of the quantity along with the standard deviation (std.), the skeweness (skew.), and the kurtosis (kurt.).

\begin{tabular}{c|cc|cc|cc|} 
& \multicolumn{2}{|c|}{ Diversification } & \multicolumn{2}{|c|}{ ACC } & \multicolumn{2}{c|}{ Returns } \\
\hline \hline & min. & max. & min. & max. & min. & max. \\
$2004-07$ & 1.000 & 3027.923 & 1.187 & 207.196 & -0.022 & 0.024 \\
$2007-10$ & 1.000 & 3117.364 & 1.000 & 396.776 & -0.043 & 0.042 \\
\hline \hline & mean & std. & mean & std. & mean & std. \\
$2004-07$ & 110.343 & 206.530 & 77.774 & 44.169 & 0.001 & 0.004 \\
$2007-10$ & 128.373 & 244.102 & 139.755 & 79.521 & 0.000 & 0.008 \\
\hline \hline & skew. & kurt. & skew. & kurt. & skew. & kurt. \\
$2004-07$ & 7.639 & 80.404 & 0.297 & 2.062 & 0.189 & 9.696 \\
$2007-10$ & 6.257 & 54.986 & 0.201 & 2.208 & 0.100 & 9.607 \\
\hline \hline
\end{tabular}

Table 1 shows summary statistics of the main quantities used throughout the paper, namely the diversification of a fund, its $A C C$ indicator and the gross returns. The measures are averages of the values obtained for two sub-periods. In the table we report the minimum, the maximum and the average value of each quantity along with the standard deviation, the skeweness and the kurtosis of the distribution. Notice how, during the (post)-crisis phase, all the topological measures increase both in the mean values and in their standard deviations, while the returns display higher standard deviations. On the other hand, the skeweness and the kurtosis remain approximately stable during the two sub-periods.

Figure 3 shows the quarterly time series of mean values of the $A C C$ for funds within the Q10-decile (in yellow), Q5-decile (in red) and the $Q 1$-decile (in blue) portfolios, along with the associated dispersion corresponding to one standard deviation (vertical bars). The Q10-decile encompasses funds with the highest $A C C$ value while the $Q 1$-decile includes those with the lowest values. We note that for the $Q 10$-decile portfolio the outbreak of the financial markets of mid-2007 corresponds to an increasing trajectory in $A C C$ levels (more pronounced with respect to the increase of the $Q 5$-decile), meaning that these funds increased even more their exposition to the most common/popular assets. By contrast, ment strategies along the line described in the paper. Since results are in line with the ones presented in the paper, for sake of brevity, we exclude them from the work but they are available from authors upon request. 
Figure 3: Distribution over the sample period of mean values of the ACC within the $Q 10$-decile (in yellow), the $Q 5$-decile (in red) and the $Q 1$-decile (in blue). The inset reproduces the results associated with the $Q 1$-decile of the ACC indicator emphasizing its dynamic over time. The associated dispersion of one standard deviation is expressed with vertical bars.

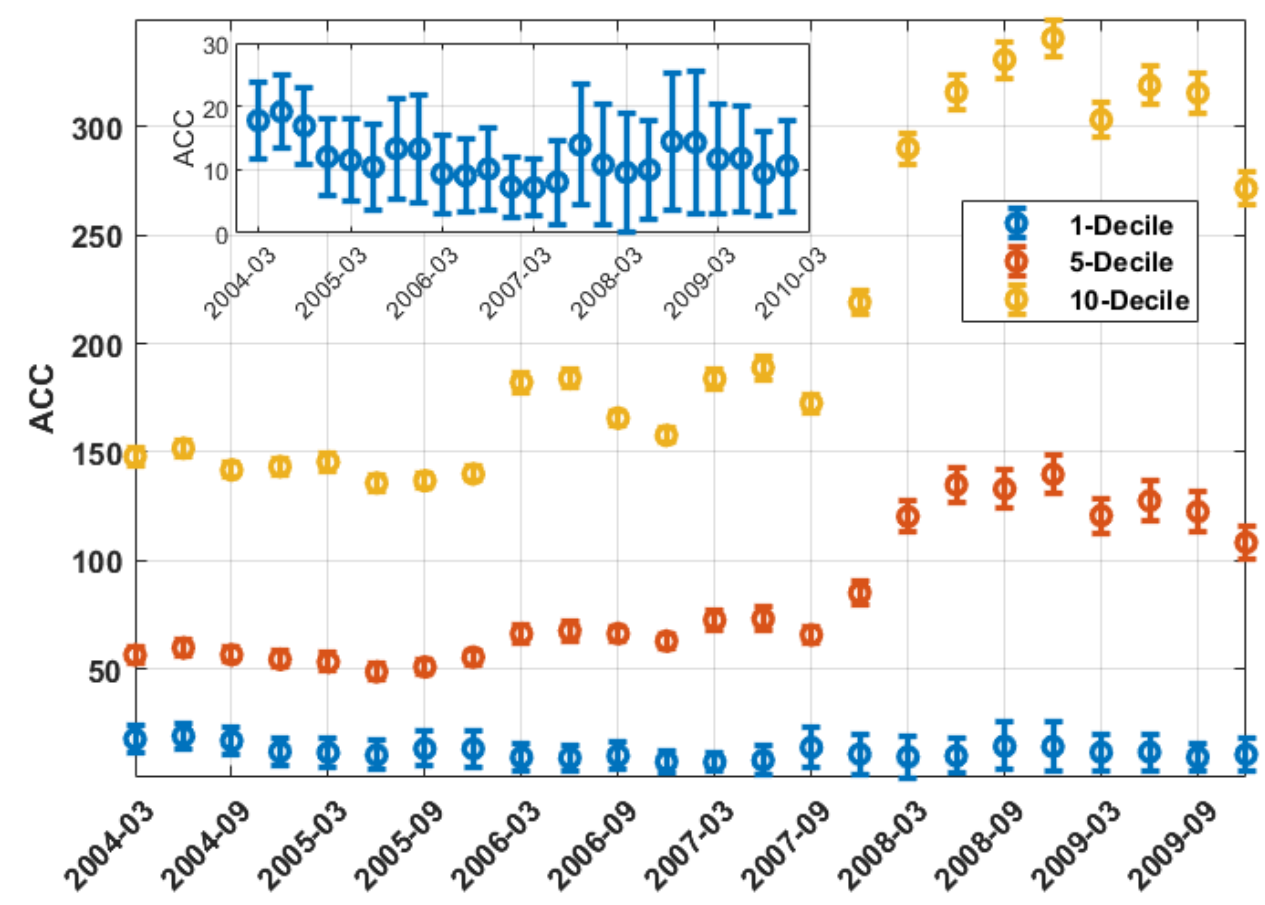

data for $Q 1$-decile shows that investments for this class of funds remained very specialized and were not affected by the onset of the crisis.

\section{Results}

At the beginning of each quarter we sort funds into deciles according to different criteria: the alphas from the three- and five-factors models estimated via standard OLS procedure ${ }^{8}$ (Fama and French $(1993,2015)$ ), the Average Commonality Coefficient $(A C C)$ and diversification $(D)$ indicators, and the measure of managerial skills $\left(\hat{\delta^{*}}\right)$ proposed by Cohen et al. (2005). The latter measure is computed as:

$$
\hat{\delta}^{*}=W^{\prime} V \hat{\alpha}
$$

\footnotetext{
${ }^{8}$ We use subscripts $3 f$ and $5 f$ to indicate alpha computed from the three- and the five-factors model, respectively. The estimate of portfolio expected return is computed as $r_{3 f}=R_{f}+\beta_{1}\left(R_{m}-R_{f}\right)+$ $\beta_{2} S M B+\beta_{3} H M L+\alpha$, where the market premium $\left(R_{m}-R_{f}\right)$ is enriched by factors that refer to Small minus Big capitalization (SMB) and High minus Low book-to-market ratio (HML); the five factors model adds to the previous three factors model the profitability and the investment factors.
} 
where $W$ is the matrix denoting the current weight of stocks in managers portfolios and $V$ represents the fraction of stocks holding with respect to the entire funds world.

We use nine months of daily observations as look-back period. For this reason we will refer hereinafter to the alpha sort of the first criterion as past- $\hat{\alpha}$. Then we calculate the return of each decile portfolio over the next three months equally weighting funds in each decile. Finally, we connect quarterly decile performances from June 2004 to June 2010, providing also separate results for observations prior to the financial crisis of mid-2007 (namely, in the interval from June 2004 to June 2007) and for the (post)-crisis period (namely, from September 2007 to June 2010).

Figure 4: Pooled distributions of past- $\hat{\alpha}$ (x-axis) vs. ACC (y-axis) prior to the crisis (upper panels) and for the (post)-crisis period (bottom panels). Each panel shows the scatter plot of the ACC measure vs. the past- $\hat{\alpha}$ along with the average values for both the $\left.\mathrm{ACC}<A C C_{3(5) f}\right\rangle$ and past- $\hat{\alpha},\langle$ past $-\hat{\alpha}\rangle$. In blue we report the results associated with the three-factors model $\left(A C C_{3 f}\right)$ while the red color emphasizes the results obtained by employing the five-factors model $\left(A C C_{5 f}\right)$.
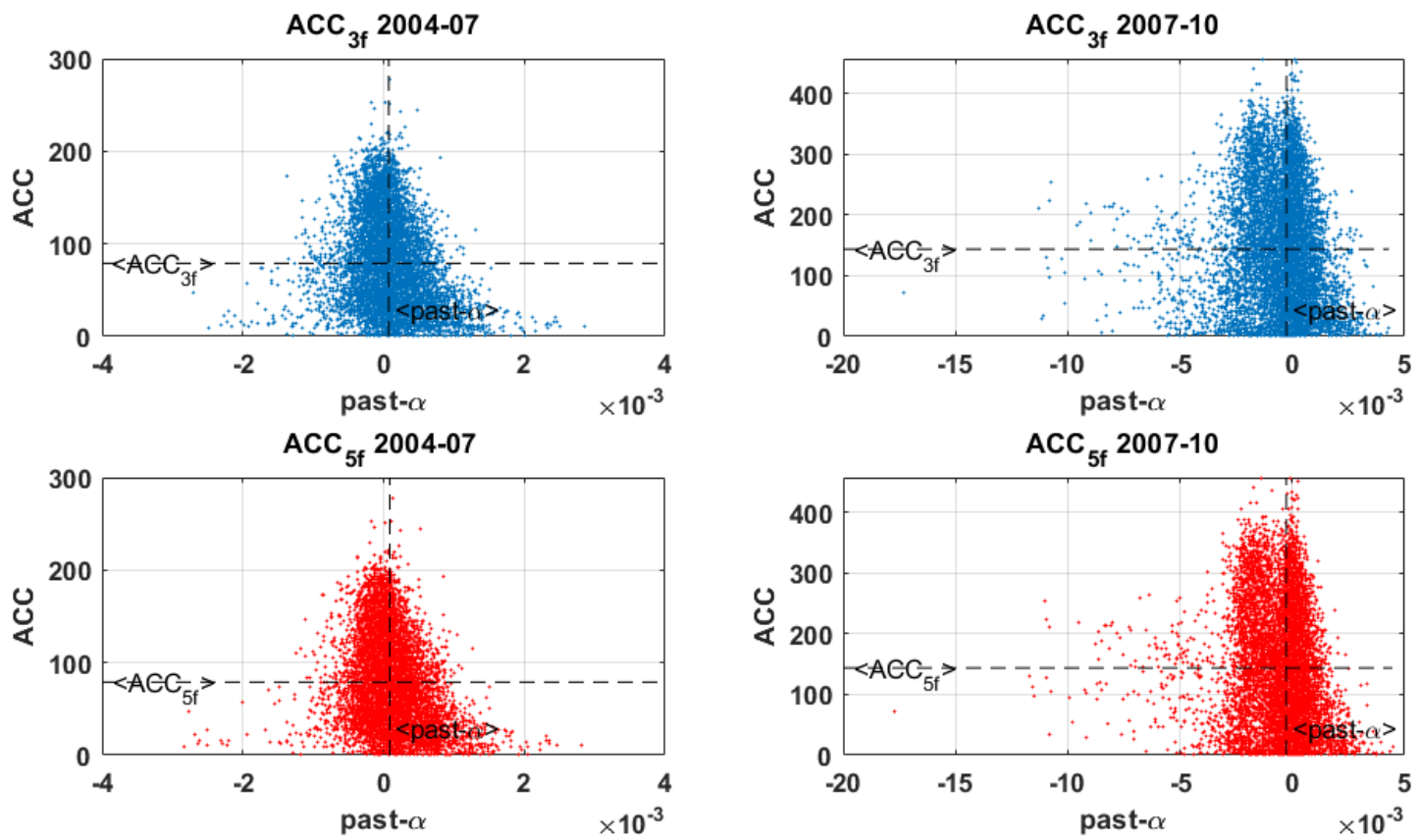

Figure 4 shows the scatter plot of the past- $\hat{\alpha}$ values against the corresponding ACC value of each fund's portfolio (top panels refer to the three-factors model while bottom panels refer to the five-factors model). Prior to the crisis of mid-2007 the distribution related to the three-factors model $\left(A C C_{3 f}\right)$ is basically bell-shaped and centered around a value of zero for past- $\hat{\alpha}$. For the five-factors model case $\left(A C C_{5 f}\right)$, the distribution, besides the bell-shape configuration, displays a slightly negative average past- $\hat{\alpha}$. This configuration changes after the crisis, in time window September 2007 - June 2010, where 
we observe a noisier left-tail in both models. High values of ACC are thus associated with less dispersed values of past- $\hat{\alpha}$, while for funds with very low values of ACC we observe a much more variability in terms of past- $\hat{\alpha}$. Those funds which are likely to invest in popular assets are, therefore, unlikely to produce large extra-performances, while those funds investing in niche assets may get extra-performances significantly deviating from zero. Investing in less common assets deserves therefore a premium for the risk of departing from the relative performance related to the asset allocation of peer investors.

Figure 5: Scatter plots of inverse ACC (G) vs. the $\hat{\delta}^{*}$ of Cohen et al. (2005) -panel (a), vs. the Diversification measure -panel (b) and vs. the funds' size -panel (c). Inside each panel we also report the results associated with the extremes of the ACC index distribution in each quarter, namely the $Q 1$-decile and the $Q 10$-decile. The blue points refer to the three-factors model whereas the red points correspond to the five-factors model.

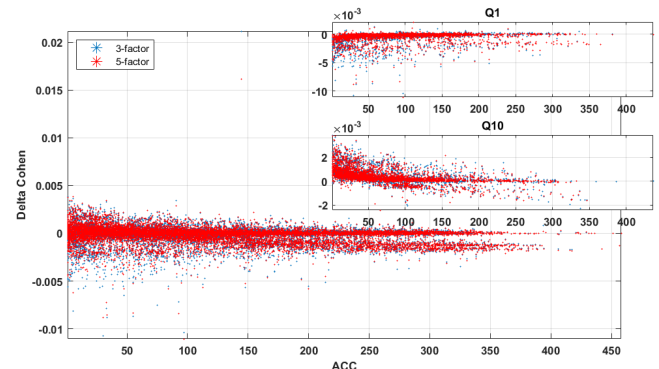

(a)

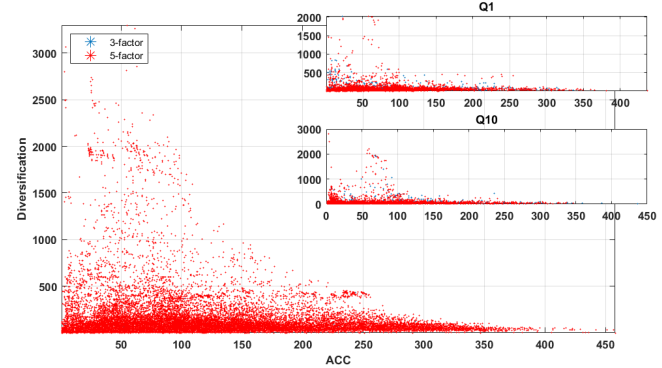

(b)

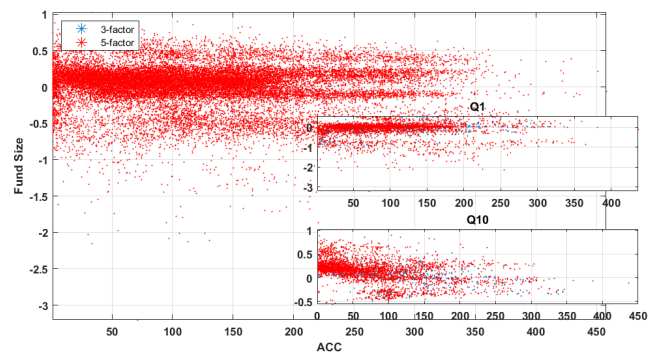

(c)

Moreover, we are also interested in studying whether the information contained in the ACC indicator is not also embedded into the other measures. For this purpose, in Figure 5 (a) we report the scatter plot of the ACC against the measure proposed by Cohen et al. (2005), in panel (b) we show the ACC vs. the diversification, and finally in panel (c) we plot the ACC against the size of the funds (computed as the sum of the market values of the constituents). Finally the inserts of each panel report the results for the $Q 1$-decile and the Q10-decile of the ACC distribution. The figures, displaying low correlations between the variables, suggest that the information contained in the ACC measure is new and not embedded in the other variables, thus emphasizing the use of this topological measure in the horse race procedure that we will present in next subsections. 


\subsection{One-way Sorting}

Table 2: Sort Funds by Past Performance - Pre Crisis. The table shows the returns of funds sorted according to various measures of past performance. The table reports the OLS estimates of decile portfolios' alphas (in percentage per year) and the corresponding absolute value of the t-statistics (in parentheses). Subscripts $3 f$ and $5 f$ stand for the three and five factors models used to compute alpha performances (Fama and French $(1993,2015)$ ). To compute past performance we use nine months of lookback period of daily observations on gross returns, which are determined by adding fund management fees to net returns. We then calculate the return of each decile portfolio over the next three months using daily returns series and equally weighting funds in each decile. Decile portfolios are redefined each quarter and the corresponding three months returns time series are connected across quarters to form a full sample period for each decile portfolio. With $\hat{\alpha}$ we refer to past- $\hat{\alpha}$ obtained from the three or five factors models. $A C C$ stands for the Average Commonality Coefficient property, while letter $D$ refers to the diversification. Finally, with $\hat{\delta}^{*}$ we refer to the delta measure of managerial skill introduced by Cohen et al. (2005). top-bottom is the portfolio obtained investing long in the best-performer decile and short funds in the worst-performer decile. The sample period is June 2004 to June 2007.

\begin{tabular}{|c|c|c|c|c|c|c|c|c|c|c|c|}
\hline & Q1 & Q2 & Q3 & Q4 & Q5 & $\overline{\mathrm{Q} 6}$ & Q7 & Q8 & $\overline{\mathrm{Q} 9}$ & Q10 & top-bottom \\
\hline$\hat{\alpha}_{5 f}$ & $\begin{array}{c}2.74 \\
(1.31)\end{array}$ & $\begin{array}{c}1.51 \\
(1.59)\end{array}$ & $\begin{array}{c}1.56 \\
(1.87)\end{array}$ & $\begin{array}{c}1.96 \\
(2.22)\end{array}$ & $\begin{array}{c}2.21 \\
(2.75)\end{array}$ & $\begin{array}{c}1.96 \\
(2.22)\end{array}$ & $\begin{array}{c}3.19 \\
(3.21)\end{array}$ & $\begin{array}{c}3.38 \\
(2.73)\end{array}$ & $\begin{array}{c}4.01 \\
(2.63)\end{array}$ & $\begin{array}{l}11.51 \\
(2.83)\end{array}$ & $\begin{array}{c}8.77 \\
(2.05)\end{array}$ \\
\hline$\hat{\alpha}_{3 f}$ & $\begin{array}{c}0.87 \\
(0.53)\end{array}$ & $\begin{array}{c}0.64 \\
(0.70)\end{array}$ & $\begin{array}{c}0.19 \\
(0.24)\end{array}$ & $\begin{array}{c}1.82 \\
(2.40)\end{array}$ & $\begin{array}{c}1.83 \\
(2.37)\end{array}$ & $\begin{array}{c}2.25 \\
(2.69)\end{array}$ & $\begin{array}{c}2.63 \\
(2.93)\end{array}$ & $\begin{array}{c}3.66 \\
(2.93)\end{array}$ & $\begin{array}{c}4.94 \\
(3.26)\end{array}$ & $\begin{array}{l}11.58 \\
(2.84)\end{array}$ & $\begin{array}{l}10.71 \\
(2.62)\end{array}$ \\
\hline$A C C_{5 f}$ & $\begin{array}{l}11.80 \\
(3.14)\end{array}$ & $\begin{array}{c}7.53 \\
(3.05)\end{array}$ & $\begin{array}{c}3.95 \\
(3.30)\end{array}$ & $\begin{array}{c}3.07 \\
(2.31)\end{array}$ & $\begin{array}{c}4.99 \\
(3.46)\end{array}$ & $\begin{array}{c}3.04 \\
(2.40)\end{array}$ & $\begin{array}{c}3.03 \\
(2.82)\end{array}$ & $\begin{array}{c}1.91 \\
(2.59)\end{array}$ & $\begin{array}{c}0.83 \\
(1.32)\end{array}$ & $\begin{array}{l}-0.05 \\
(0.10)\end{array}$ & $\begin{array}{l}11.85 \\
(3.23)\end{array}$ \\
\hline$A C C_{3 f}$ & $\begin{array}{l}11.22 \\
(3.00)\end{array}$ & $\begin{array}{c}7.13 \\
(2.91)\end{array}$ & $\begin{array}{c}3.64 \\
(3.16)\end{array}$ & $\begin{array}{c}2.70 \\
(2.11)\end{array}$ & $\begin{array}{c}4.58 \\
(3.26)\end{array}$ & $\begin{array}{c}2.76 \\
(2.23)\end{array}$ & $\begin{array}{c}2.82 \\
(2.68)\end{array}$ & $\begin{array}{c}1.79 \\
(2.48)\end{array}$ & $\begin{array}{c}0.72 \\
(1.19)\end{array}$ & $\begin{array}{l}-0.13 \\
(0.26)\end{array}$ & $\begin{array}{l}11.36 \\
(3.12)\end{array}$ \\
\hline$D_{5 f}$ & $\begin{array}{l}10.85 \\
(2.68)\end{array}$ & $\begin{array}{c}6.80 \\
(2.72)\end{array}$ & $\begin{array}{c}4.35 \\
(3.35)\end{array}$ & $\begin{array}{c}3.66 \\
(3.32)\end{array}$ & $\begin{array}{c}3.11 \\
(3.45)\end{array}$ & $\begin{array}{c}2.75 \\
(2.88)\end{array}$ & $\begin{array}{c}1.91 \\
(2.04)\end{array}$ & $\begin{array}{c}2.42 \\
(2.84)\end{array}$ & $\begin{array}{c}1.90 \\
(2.23)\end{array}$ & $\begin{array}{c}0.57 \\
(0.98)\end{array}$ & $\begin{array}{l}10.28 \\
(2.67)\end{array}$ \\
\hline$D_{3 f}$ & $\begin{array}{c}10.65 \\
(2.62)\end{array}$ & $\begin{array}{c}6.33 \\
(2.55)\end{array}$ & $\begin{array}{c}4.00 \\
(3.14)\end{array}$ & $\begin{array}{c}3.26 \\
(3.06)\end{array}$ & $\begin{array}{c}2.80 \\
(3.21)\end{array}$ & $\begin{array}{c}2.52 \\
(2.74)\end{array}$ & $\begin{array}{c}1.63 \\
(1.79)\end{array}$ & $\begin{array}{c}2.17 \\
(2.64)\end{array}$ & $\begin{array}{c}1.68 \\
(2.02)\end{array}$ & $\begin{array}{c}0.45 \\
(0.80)\end{array}$ & $\begin{array}{l}10.20 \\
(2.64)\end{array}$ \\
\hline$\hat{\delta}^{*}{ }_{5 f}$ & $\begin{array}{c}4.44 \\
(2.08)\end{array}$ & $\begin{array}{c}1.98 \\
(1.50)\end{array}$ & $\begin{array}{c}1.37 \\
(1.42)\end{array}$ & $\begin{array}{c}1.23 \\
(1.65)\end{array}$ & $\begin{array}{c}1.29 \\
(1.66)\end{array}$ & $\begin{array}{c}1.61 \\
(1.84)\end{array}$ & $\begin{array}{c}2.15 \\
(2.11)\end{array}$ & $\begin{array}{c}2.34 \\
(1.94)\end{array}$ & $\begin{array}{c}4.30 \\
(2.83)\end{array}$ & $\begin{array}{l}12.40 \\
(2.89)\end{array}$ & $\begin{array}{c}7.96 \\
(1.83)\end{array}$ \\
\hline$\hat{\delta}^{*}{ }_{3 f}$ & $\begin{array}{c}2.51 \\
(1.39)\end{array}$ & $\begin{array}{c}1.12 \\
(1.10)\end{array}$ & $\begin{array}{c}0.87 \\
(1.15)\end{array}$ & $\begin{array}{c}1.09 \\
(1.56)\end{array}$ & $\begin{array}{c}1.02 \\
(1.43)\end{array}$ & $\begin{array}{c}1.18 \\
(1.44)\end{array}$ & $\begin{array}{c}1.57 \\
(1.64)\end{array}$ & $\begin{array}{c}2.36 \\
(1.97)\end{array}$ & $\begin{array}{c}4.59 \\
(3.03)\end{array}$ & $\begin{array}{l}12.89 \\
(2.94)\end{array}$ & $\begin{array}{l}10.39 \\
(2.47)\end{array}$ \\
\hline
\end{tabular}

In this Section we report the results of the comparison of the alphas for each decile according to different measures of past performance, with the aim of identifying the one which gives highest profitability before and after the crisis. Table 2 shows the annualized post-ranking alphas for each decile portfolio (sorted from the lowest Q1 to the highest Q10) during the pre-crisis period, calculated using both the three- and five- factors models. It also reports the performance of the portfolio long in the top best performer decile and short in the bottom worst performer decile (namely, top-bottom portfolio ${ }^{9}$ ). The performance of the top-bottom portfolio built according to the past- $\hat{\alpha}$ sort produces consistent (about [8.77; 10.71]) and significant (t-statistics [2.05; 2.62]) annual returns, thus supporting the view of predictability of funds' returns based on past- $\hat{\alpha}$ performances. By using, as

\footnotetext{
${ }^{9}$ For the topological properties $A C C$ and diversification the top best performer decile refers to Q1, while it is Q10 for past- $\hat{\alpha}$ and the $\hat{\delta}^{*}$ indicator of Cohen et al. (2005).
} 
Table 3: Sort Funds by Past Performance - Crisis. The table shows the returns of funds sorted according to various measures of past performance. The table reports the OLS estimates of decile portfolios' alphas (in percentage per year) and the corresponding absolute value of the t-statistics (in parentheses). Subscripts $3 f$ and $5 f$ stand for the three and five factors models used to compute alpha performances (Fama and French $(1993,2015)$ ). To compute past performance we use nine months of lookback period of daily observations on gross returns, which are determined by adding fund management fees to net returns. We then calculate the return of each decile portfolio over the next three months using daily returns series and equally weighting funds in each decile. Decile portfolios are redefined each quarter and the corresponding three months returns time series are connected across quarters to form a full sample period for each decile portfolio. With $\hat{\alpha}$ we refer to past- $\hat{\alpha}$ obtained from the three or five factors models. $A C C$ stands for the Average Commonality Coefficient property, while letter $D$ refers to the diversification. Finally, with $\hat{\delta^{*}}$ we refer to the delta measure of managerial skill introduced by Cohen et al. (2005). top-bottom is the portfolio obtained investing long in the best-performer decile and short funds in the worst-performer decile. The sample period is September 2007 to June 2010.

\begin{tabular}{|c|c|c|c|c|c|c|c|c|c|c|c|}
\hline & QQ1 & $\overline{\mathrm{Q} 2}$ & QQ3 & Q44 & Q5 & $\overline{Q Q 6}$ & Q7 & Q8 & Q99 & Q10 & top-bottom \\
\hline$\hat{\alpha}_{5 f}$ & $\begin{array}{c}-14.74 \\
(2.11)\end{array}$ & $\begin{array}{l}-5.17 \\
(1.04)\end{array}$ & $\begin{array}{c}-7.34 \\
(1.82)\end{array}$ & $\begin{array}{l}-5.37 \\
(1.68)\end{array}$ & $\begin{array}{l}-5.70 \\
(1.76)\end{array}$ & $\begin{array}{l}-4.15 \\
(1.27)\end{array}$ & $\begin{array}{l}-5.14 \\
(1.41)\end{array}$ & $\begin{array}{l}-5.27 \\
(1.51)\end{array}$ & $\begin{array}{l}-4.56 \\
(1.27)\end{array}$ & $\begin{array}{l}-5.84 \\
(0.88)\end{array}$ & $\begin{array}{c}8.90 \\
(1.07)\end{array}$ \\
\hline$\hat{\alpha}_{3 f}$ & $\begin{array}{c}-13.10 \\
(2.06)\end{array}$ & $\begin{array}{l}-7.05 \\
(1.34)\end{array}$ & $\begin{array}{c}-7.93 \\
(1.91)\end{array}$ & $\begin{array}{l}-5.38 \\
(1.59)\end{array}$ & $\begin{array}{l}-5.27 \\
(1.58)\end{array}$ & $\begin{array}{l}-4.24 \\
(1.27)\end{array}$ & $\begin{array}{l}-4.79 \\
(1.37)\end{array}$ & $\begin{array}{l}-5.38 \\
(1.49)\end{array}$ & $\begin{array}{l}-3.69 \\
(1.22)\end{array}$ & $\begin{array}{l}-3.34 \\
(0.65)\end{array}$ & $\begin{array}{c}9.76 \\
(1.44)\end{array}$ \\
\hline$A C C_{5 f}$ & $\begin{array}{c}-7.51 \\
(1.04)\end{array}$ & $\begin{array}{l}-5.41 \\
(0.97)\end{array}$ & $\begin{array}{c}-4.02 \\
(1.41)\end{array}$ & $\begin{array}{l}-4.23 \\
(1.38)\end{array}$ & $\begin{array}{l}-5.61 \\
(1.58)\end{array}$ & $\begin{array}{l}-5.97 \\
(1.52)\end{array}$ & $\begin{array}{l}-4.91 \\
(1.33)\end{array}$ & $\begin{array}{l}-7.56 \\
(1.95)\end{array}$ & $\begin{array}{l}-7.54 \\
(1.95)\end{array}$ & $\begin{array}{l}-6.59 \\
(1.81)\end{array}$ & $\begin{array}{c}-0.92 \\
(0.13)\end{array}$ \\
\hline$A C C_{3 f}$ & $\begin{array}{c}-6.11 \\
(0.86)\end{array}$ & $\begin{array}{l}-4.61 \\
(0.85)\end{array}$ & $\begin{array}{c}-4.07 \\
(1.52)\end{array}$ & $\begin{array}{l}-3.91 \\
(1.35)\end{array}$ & $\begin{array}{l}-5.20 \\
(1.51)\end{array}$ & $\begin{array}{l}-5.76 \\
(1.50)\end{array}$ & $\begin{array}{l}-4.97 \\
(1.37)\end{array}$ & $\begin{array}{l}-7.08 \\
(1.84)\end{array}$ & $\begin{array}{l}-7.42 \\
(1.92)\end{array}$ & $\begin{array}{l}-7.09 \\
(1.94)\end{array}$ & $\begin{array}{c}0.98 \\
(0.14)\end{array}$ \\
\hline$D_{5 f}$ & $\begin{array}{c}-7.24 \\
(1.10)\end{array}$ & $\begin{array}{l}-6.09 \\
(1.24)\end{array}$ & $\begin{array}{c}-5.69 \\
(1.64)\end{array}$ & $\begin{array}{l}-5.34 \\
(1.52)\end{array}$ & $\begin{array}{l}-6.18 \\
(1.78)\end{array}$ & $\begin{array}{l}-5.45 \\
(1.50)\end{array}$ & $\begin{array}{l}-7.50 \\
(2.11)\end{array}$ & $\begin{array}{l}-5.95 \\
(1.76)\end{array}$ & $\begin{array}{l}-5.52 \\
(1.70)\end{array}$ & $\begin{array}{l}-5.93 \\
(1.89)\end{array}$ & $\begin{array}{l}-1.31 \\
(0.26)\end{array}$ \\
\hline$D_{3 f}$ & $\begin{array}{c}-6.53 \\
(0.99)\end{array}$ & $\begin{array}{l}-5.19 \\
(1.07)\end{array}$ & $\begin{array}{c}-5.40 \\
(1.58)\end{array}$ & $\begin{array}{l}-5.08 \\
(1.47)\end{array}$ & $\begin{array}{l}-5.82 \\
(1.72)\end{array}$ & $\begin{array}{l}-5.47 \\
(1.54)\end{array}$ & $\begin{array}{l}-7.10 \\
(2.08)\end{array}$ & $\begin{array}{l}-5.81 \\
(1.77)\end{array}$ & $\begin{array}{l}-5.46 \\
(1.72)\end{array}$ & $\begin{array}{l}-6.03 \\
(1.96)\end{array}$ & $\begin{array}{l}-0.50 \\
(0.10)\end{array}$ \\
\hline$\hat{\delta}^{*}{ }_{5 f}$ & $\begin{array}{r}-11.01 \\
(1.47)\end{array}$ & $\begin{array}{l}-8.12 \\
(1.56)\end{array}$ & $\begin{array}{c}-6.02 \\
(1.58)\end{array}$ & $\begin{array}{l}-6.47 \\
(1.93)\end{array}$ & $\begin{array}{l}-5.82 \\
(1.57)\end{array}$ & $\begin{array}{l}-5.03 \\
(1.45)\end{array}$ & $\begin{array}{l}-4.70 \\
(1.32)\end{array}$ & $\begin{array}{l}-5.14 \\
(1.46)\end{array}$ & $\begin{array}{l}-4.98 \\
(1.43)\end{array}$ & $\begin{array}{l}-6.66 \\
(0.99)\end{array}$ & $\begin{array}{c}4.35 \\
(0.48)\end{array}$ \\
\hline$\hat{\delta}^{*} 3 f$ & $\begin{array}{c}-10.93 \\
(1.47)\end{array}$ & $\begin{array}{l}-7.56 \\
(1.43)\end{array}$ & $\begin{array}{c}-6.50 \\
(1.62)\end{array}$ & $\begin{array}{l}-7.37 \\
(2.02)\end{array}$ & $\begin{array}{c}-6.93 \\
(1.77)\end{array}$ & $\begin{array}{c}-4.99 \\
(1.34)\end{array}$ & $\begin{array}{c}-3.92 \\
(1.15)\end{array}$ & $\begin{array}{l}-5.49 \\
(1.71)\end{array}$ & $\begin{array}{c}-3.31 \\
(1.02)\end{array}$ & $\begin{array}{c}-3.76 \\
(0.71)\end{array}$ & $\begin{array}{c}7.17 \\
(0.91)\end{array}$ \\
\hline
\end{tabular}

ranking measure, the ACC or the diversification property we get significant and even higher top-bottom annual extra-performances (about $[11.85 ; 11.36]$ per cent for the ACC and $[10.28 ; 10.20]$ per cent for diversification). In addition, as alternative indicator to judge managerial skills we report the performances related to the sort of past performances based on the measure proposed by Cohen et al. (2005), obtaining similar results as those related to the other ranking criteria (about $[7.96 ; 10.39]$ per cent). These results are significant not only economically but also statistically, supporting the use of these sort criteria to build portfolios. Hence, all the measures presented in Table 2 seem capable of generating future extra-performances when combined in a top-bottom portfolio strategy.

The impact of 2007-08 financial crisis deteriorated market performances and heavily impacted the mutual fund sector. Despite the negative outcomes occurred along the interval 2007-2010, annualized extra-performances for top-bottom portfolios shown in Table 3 are still positive when using past- $\hat{\alpha}$ or $\hat{\delta}^{*}$ as sorting criteria, although poorly statistically 
Table 4: Sort Funds by Past Performance. The table shows the returns of funds sorted according to various measures of past performance. The table reports the OLS estimates of decile portfolios' alphas (in percentage per year) and the corresponding absolute value of the t-statistics (in parentheses). Subscripts $3 f$ and $5 f$ stand for the three and five factors models used to compute alpha performances (Fama and French (1993, 2015)). To compute past performance we use nine months of lookback period of daily observations on gross returns, which are determined by adding fund management fees to net returns. We then calculate the return of each decile portfolio over the next three months using daily returns series and equally weighting funds in each decile. Decile portfolios are redefined each quarter and the corresponding three months returns time series are connected across quarters to form a full sample period for each decile portfolio. With $\hat{\alpha}$ we refer to past- $\hat{\alpha}$ obtained from the three or five factors models. $A C C$ stands for the Average Commonality Coefficient property, while letter $D$ refers to the diversification. Finally, with $\hat{\delta^{*}}$ we refer to the delta measure of managerial skill introduced by Cohen et al. (2005). top-bottom is the portfolio obtained investing long in the best-performer decile and short funds in the worst-performer decile. The sample period is June 2004 to June 2010.

\begin{tabular}{|c|c|c|c|c|c|c|c|c|c|c|c|}
\hline & Q1 & Q2 & Q3 & Q4 & Q5 & Q6 & Q7 & Q8 & Q9 & Q10 & top-bottom \\
\hline$\hat{\alpha}_{5 f}$ & $\begin{array}{l}-5.28 \\
(1.52)\end{array}$ & $\begin{array}{l}-1.38 \\
(0.58)\end{array}$ & $\begin{array}{l}-2.31 \\
(1.20)\end{array}$ & $\begin{array}{l}-1.25 \\
(0.80)\end{array}$ & $\begin{array}{l}-1.21 \\
(0.78)\end{array}$ & $\begin{array}{c}-0.46 \\
(0.29)\end{array}$ & $\begin{array}{l}-0.31 \\
(0.18)\end{array}$ & $\begin{array}{l}-0.33 \\
(0.19)\end{array}$ & $\begin{array}{c}0.39 \\
(0.21)\end{array}$ & $\begin{array}{c}3.65 \\
(0.97)\end{array}$ & $\begin{array}{c}8.93 \\
(1.94)\end{array}$ \\
\hline$\hat{\alpha}_{3 f}$ & $\begin{array}{c}-5.14 \\
(1.68)\end{array}$ & $\begin{array}{l}-2.57 \\
(1.04)\end{array}$ & $\begin{array}{l}-3.28 \\
(1.67)\end{array}$ & $\begin{array}{l}-1.25 \\
(0.77)\end{array}$ & $\begin{array}{l}-1.16 \\
(0.73)\end{array}$ & $\begin{array}{c}-0.43 \\
(0.27)\end{array}$ & $\begin{array}{l}-0.51 \\
(0.30)\end{array}$ & $\begin{array}{l}-0.12 \\
(0.07)\end{array}$ & $\begin{array}{c}1.37 \\
(0.84)\end{array}$ & $\begin{array}{c}5.12 \\
(1.57)\end{array}$ & $\begin{array}{l}10.25 \\
(2.64)\end{array}$ \\
\hline$A C C_{5 f}$ & $\begin{array}{c}3.62 \\
(0.92)\end{array}$ & $\begin{array}{c}1.96 \\
(0.68)\end{array}$ & $\begin{array}{c}0.24 \\
(0.16)\end{array}$ & $\begin{array}{l}-0.10 \\
(0.06)\end{array}$ & $\begin{array}{c}0.21 \\
(0.12)\end{array}$ & $\begin{array}{c}-0.82 \\
(0.42)\end{array}$ & $\begin{array}{l}-0.42 \\
(0.23)\end{array}$ & $\begin{array}{l}-2.40 \\
(1.30)\end{array}$ & $\begin{array}{l}-2.85 \\
(1.56)\end{array}$ & $\begin{array}{l}-2.89 \\
(1.66)\end{array}$ & $\begin{array}{c}6.51 \\
(1.67)\end{array}$ \\
\hline$A C C_{3 f}$ & $\begin{array}{c}4.00 \\
(1.03)\end{array}$ & $\begin{array}{c}1.95 \\
(0.68)\end{array}$ & $\begin{array}{c}0.16 \\
(0.11)\end{array}$ & $\begin{array}{l}-0.18 \\
(0.12)\end{array}$ & $\begin{array}{c}0.20 \\
(0.12)\end{array}$ & $\begin{array}{l}-0.88 \\
(0.47)\end{array}$ & $\begin{array}{l}-0.41 \\
(0.23)\end{array}$ & $\begin{array}{l}-2.09 \\
(1.15)\end{array}$ & $\begin{array}{l}-2.60 \\
(1.43)\end{array}$ & $\begin{array}{l}-2.88 \\
(1.65)\end{array}$ & $\begin{array}{c}6.88 \\
(1.77)\end{array}$ \\
\hline$D_{5 f}$ & $\begin{array}{c}2.92 \\
(0.78)\end{array}$ & $\begin{array}{c}1.22 \\
(0.46)\end{array}$ & $\begin{array}{l}-0.02 \\
(0.01)\end{array}$ & $\begin{array}{l}-0.30 \\
(0.18)\end{array}$ & $\begin{array}{l}-0.95 \\
(0.57)\end{array}$ & $\begin{array}{c}-0.97 \\
(0.55)\end{array}$ & $\begin{array}{l}-2.20 \\
(1.28)\end{array}$ & $\begin{array}{l}-1.27 \\
(0.77)\end{array}$ & $\begin{array}{l}-1.30 \\
(0.82)\end{array}$ & $\begin{array}{l}-2.14 \\
(1.43)\end{array}$ & $\begin{array}{c}5.06 \\
(1.61)\end{array}$ \\
\hline$D_{3 f}$ & $\begin{array}{c}2.85 \\
(0.76)\end{array}$ & $\begin{array}{c}1.42 \\
(0.54)\end{array}$ & $\begin{array}{l}-0.04 \\
(0.02)\end{array}$ & $\begin{array}{l}-0.25 \\
(0.15)\end{array}$ & $\begin{array}{l}-0.80 \\
(0.49)\end{array}$ & $\begin{array}{l}-0.78 \\
(0.45)\end{array}$ & $\begin{array}{l}-2.14 \\
(1.29)\end{array}$ & $\begin{array}{l}-1.12 \\
(0.70)\end{array}$ & $\begin{array}{l}-1.24 \\
(0.81)\end{array}$ & $\begin{array}{l}-2.24 \\
(1.53)\end{array}$ & $\begin{array}{c}5.09 \\
(1.62)\end{array}$ \\
\hline$\hat{\delta}^{*}{ }_{5 f}$ & $\begin{array}{l}-2.19 \\
(0.59)\end{array}$ & $\begin{array}{l}-2.41 \\
(0.95)\end{array}$ & $\begin{array}{l}-2.10 \\
(1.13)\end{array}$ & $\begin{array}{l}-2.32 \\
(1.43)\end{array}$ & $\begin{array}{l}-1.73 \\
(0.97)\end{array}$ & $\begin{array}{c}-1.15 \\
(0.69)\end{array}$ & $\begin{array}{l}-0.66 \\
(0.38)\end{array}$ & $\begin{array}{l}-0.67 \\
(0.38)\end{array}$ & $\begin{array}{c}0.34 \\
(0.19)\end{array}$ & $\begin{array}{c}3.59 \\
(0.91)\end{array}$ & $\begin{array}{c}5.78 \\
(1.17)\end{array}$ \\
\hline$\hat{\delta}^{*}{ }_{3 f}$ & $\begin{array}{l}-2.99 \\
(0.84)\end{array}$ & $\begin{array}{l}-2.46 \\
(0.98)\end{array}$ & $\begin{array}{l}-2.31 \\
(1.21)\end{array}$ & $\begin{array}{l}-2.62 \\
(1.52)\end{array}$ & $\begin{array}{l}-2.31 \\
(1.25)\end{array}$ & $\begin{array}{c}-1.26 \\
(0.71)\end{array}$ & $\begin{array}{l}-0.56 \\
(0.34)\end{array}$ & $\begin{array}{l}-0.88 \\
(0.54)\end{array}$ & $\begin{array}{c}1.26 \\
(0.73)\end{array}$ & $\begin{array}{c}5.28 \\
(1.54)\end{array}$ & $\begin{array}{c}8.28 \\
(1.88)\end{array}$ \\
\hline
\end{tabular}

significant. Conversely, our topological indicators seem not able to determine positive results, presenting also a not clear monotonic pattern along the decile portfolios. Thus, the crisis of 2007-2008 undermined the relationship between performances and the topological properties of the portfolios that, instead, emerged as a complementary source of information prior to the crisis.

More generally, results for the entire sample period show positive and consistent topbottom extra-performances (in a range from about 5 to 10 per cent) as reported in Table 4. Interestingly, top-bottom portfolios obtained using both past- $\hat{\alpha}$ and $\hat{\delta}^{*}$ sorting criteria appear less affected by the onset of the financial crisis, while sorting according to the topological indicator reflects the changes occurred across the crisis and that perturbed the relationship with performances as discussed above. Finally, for each sorting criteria we confirm that results for the overall sample period indicate a clear monotonic pattern in the way the corresponding horse-race strategy generates extra-performances across the decile 
portfolios. Findings are finally robust to the choice to utilize the three- or five-factors models to measure alphas, being very similar in terms of resulting extra-performances and significance levels in each period.

To limit potential issues due to the presence of outliers in the distribution of ACC, we finally drop those funds in the tails corresponding to both the top and bottom five per cent of the ACC distribution in each decile portfolio. Table 5 shows this Core ACC case, confirming that previous findings hold even for more cohesive decile partitions.

Table 5: Sort Funds by Past Performance - Core case. The table exhibits the one-way sort performances for decile portfolios based on ACC. For each decile portfolio we drop those funds in the tails corresponding to both the top and bottom 5 per cent of the ACC distribution in each decile portfolio. The table reports the OLS estimates of decile portfolios' alphas (in percentage per year) and the corresponding absolute value of the t-statistics (in parentheses). Subscripts $3 f$ and $5 f$ stand for the three and five factor models used to compute alpha performances (Fama and French (1993, 2015)). To compute past performance we use nine months of lookback period of daily observations on gross returns, which are determined by adding fund management fees to net returns. We then calculate the return of each decile portfolio over the next three months using daily returns series and equally weighting funds in each decile. Decile portfolios are redefined each quarter and the corresponding three months returns time series are connected across quarters to form a full sample period for each decile portfolio. top-bottom is the portfolio obtained investing long in the best-performer decile and short funds in the worst-performer decile. Panel A stands for the interval from June 2004 to June 2007, Panel B refers to the period from September 2007 to June 2010, and Panel C from June 2004 to June 2010.

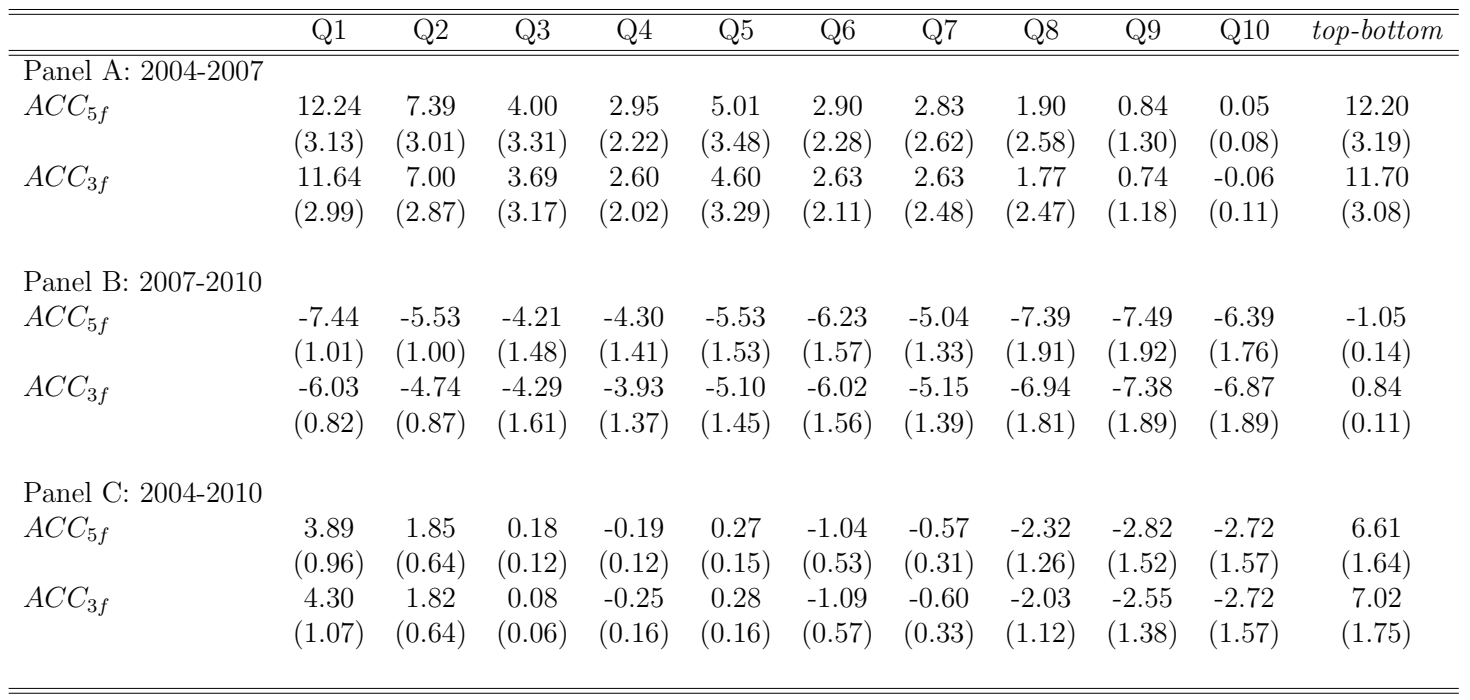

\subsection{Inspecting the Mechanism behind the Performance of the $A C C$ Indicator}

The previous analysis highlights a positive correlation between fund performance and the level of specialization of its portfolio. Funds with a low ACC portfolios (high specialization) seem to gain higher extra-performances with respect to funds that invest in more popular assets. This can be due to the fact that those specialized funds may be more informed and more able to extract profits from this information. Nevertheless, the 2007 financial crisis modified the relationships between funds and constituents, thus also the 
connection between the ACC index and the past- $\hat{\alpha}$.

We investigate with a higher time resolution the effects of the crisis on funds' performances and the relationship between performance and specialization. Previous results are obtained by dividing the sample into two sub-periods, from 2004 to 2007 and from 2007 to 2010. This aggregation prevents to focus specifically on the crisis period, therefore, in this subsection, we show the horse-race results on a more granular time scale that is quarter by quarter. Since our main goal is to assess whether the ACC measure reveals some information on funds' performance, we focus on the one-way sort. As before we employ nine months as look-back period but the alpha values are here computed for two portfolios only, namely the high-specialization (low ACC) portfolio and the low-specialization portfolio (high ACC). As a reference threshold to divide the funds into these two samples, we apply the median value of the $\mathrm{ACC}^{10}$.

Figure 6: Annualized quarterly extra-performance ( $\hat{\alpha})$ for portfolios composed by low-ACC (red) funds and high-ACC (blue) funds. Each plot shows the annualized $\hat{\alpha}$ computed at each quarter for the high vs. low ACC portfolios together with the appropriate standard deviation (dashed lines). The left panel reports the results obtained with the three-factors model while the right panel encompasses the extra-returns computed with the five-factors model.
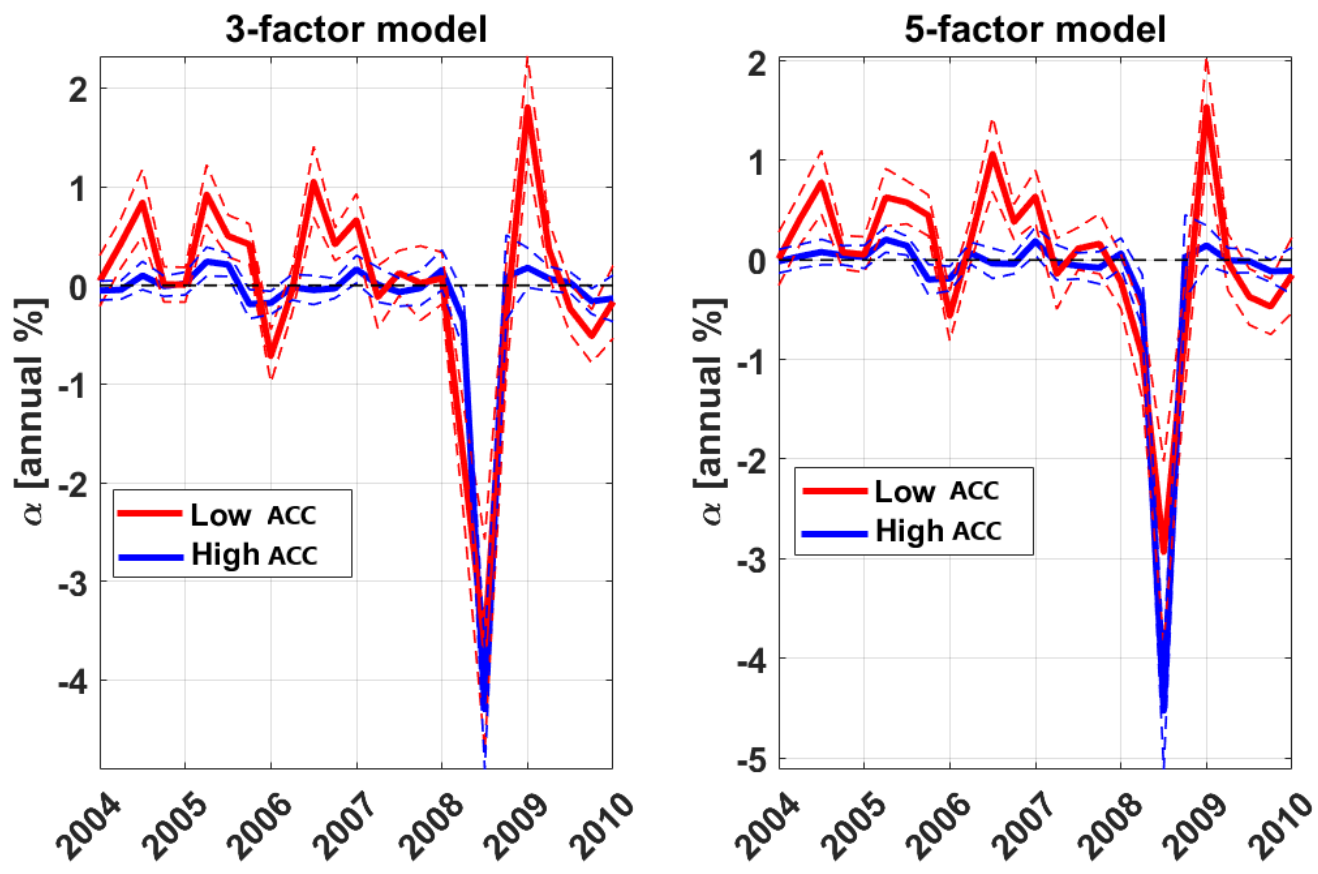

Figure 6 reports the annualized quarterly extra-performances $(\hat{\alpha})$ obtained by employing the three-factors model (left) and the five-factors model (right). From the figure clearly emerges that funds with a relative low value of $A C C$ on average perform better than funds investing in more popular assets. The red line, indicating the $\hat{\alpha}$ value for

\footnotetext{
${ }^{10}$ This choice prevents estimates with few data points. Results are qualitatively similar to those obtained using tertiles for the ACC distribution.
} 
a portfolio composed by low- $A C C$ funds, is almost always positive, thus reinforcing the finding that funds investing in market niches are more likely to be informed and able to extract profit from these exposures. The blue line, on the other hand, suggests that funds investing in more common assets obtain virtually null $\hat{\alpha}$, meaning that are not able to beat systematically the market.

The years of the global financial crisis deteriorate the performances of all the funds irrespective from their $A C C$ values. Nevertheless, funds with a high $A C C$ value seem to be more affected by the crisis in both the three-factors and five-factors models. The low $A C C$ of funds' portfolios arises as an important topological property, from an investor perspective, also during crisis phases. Indeed, specialized funds investing in niche assets, despite suffering for the systemic impact of the crisis of mid-2007, seem to be less affected by the second round of the crisis in which fire sales deteriorate most the market prices of commonly holding assets.

\subsection{Double Sorts}

To better understand the results of the above horse-race, we perform a more in depth analysis within each decile. In particular, we are interested in understanding whether the topological properties of the funds have information not contained in the alpha measures and that can be, therefore, exploited to forecast funds' performances. We focus on the use of the more sophisticated topological measure, i.e. the $A C C$ measure, by employing a double sort between past- $\hat{\alpha}$ quintiles and, within these quintiles, by further splitting funds in quintiles according to the $A C C$ levels of the portfolios. The resulting $5 \times 5$ portfolios are then mapped in time, with quarterly rebalancing, to study the distribution of alpha performances as a function of this topological property but given the same quintile level of past- $\hat{\alpha}$ performance in the first sort. Tables $6-8$ report, for different time windows, the resulting alpha performances for the $5 \times 5$ portfolios as well as for the top-bottom portfolios that buy funds with low $A C C$ values and short funds with high values of $A C C$ within a given past- $\hat{\alpha}$ quintile. Finally, the portfolio denoted as $A v g$ invests equally in each of the five quintile portfolios by row, thus representing our cleanest measure of whether the $A C C$ index contains additional information. To provide robustness for our results, panels 
$\mathrm{B}$ in Tables $6-8$ present the results related to the Core case for $A C C$ where we basically drop those funds in the tails corresponding to both the top and bottom 5 per cent of the $A C C$ distribution in each $5 \times 5$ portfolio.

Empirical findings in Table 6 show that those funds belonging to the top past- $\hat{\alpha}$ quintile (i.e., Q5) are not only able to generate persistent extra-performances than those in the bottom past- $\hat{\alpha}$ quintile (i.e., Q1), as already seen in subsection 3.1, but that, focusing within each of these past- $\hat{\alpha}$ quintiles, we get different distributions of performances based on the level of the $A C C$ index. Interestingly, the average difference prior to the crisis between the top-bottom quintiles ranked by $A C C$ is above 6 per cent, being significant both economically and statistically. These extra-performances suggest, therefore, that the ACC index contains information above and beyond past- $\hat{\alpha}$ sort that can be exploited to forecast funds' returns.

The $A C C$ property seems to have a substantial impact on the extra-performances of the top past- $\hat{\alpha}$ quintile. In fact, the double sorts procedure indicates that, among funds with higher past- $\hat{\alpha}$ (i.e., Q5), those with more specialized portfolios (low $A C C$ ) (i.e., ACC1) are more likely to obtain higher extra-returns than those with portfolios characterized by more popular assets (i.e., ACC5). In particular, annualized extra-performances for portfolio Q5ACC1 is about [17.10; 17.98] per cent, while for Q5ACC5 is about [3.73; 5.51] per cent, with decreasing pattern in the middle of the $A C C$ distribution within Q5. Hence, very skilled managers, namely those with high past- $\hat{\alpha}$, and with niche investment exposures, namely investing in assets not very common across other portfolios, are more prone to produce substantial positive extra-performances. This result suggests that managerial skills in detecting and picking assets are practically more effective especially for those managers with better past performances (i.e., Q5ACC1). By contrast, those funds in the bottom-alpha quintile (i.e., Q1) reach lower performances and do not show a clear relationship with the $A C C$ property of their portfolios. For the latter, fund managers investing in niche or popular assets do not seem to be in general really informative, while among skilled managers, those investing in less common assets are likely to generate better future returns, at least prior to the crisis of mid-2007.

Conversely, results for the crisis period (i.e., 2007-2010) depict the $A C C$ property as 
less able to add valuable information in the construction of better performing portfolios (see Table 7). Once having previously partitioned the sample according to past- $\hat{\alpha}$, still lower values for the $A C C$ index seem to generate better results than for higher ones, but results are in general not statistically significant. After the outbreak of financial markets, fund managers seem less able to gain from investing in niche vs. popular assets as instead we observed from allocations prior to the crisis. The systemic crisis affecting the global economy in mid-2007 is likely to have made financial markets much more correlated than in the previous years, thus reducing the attitude of fund managers to deviate from common investment behaviors in the pursuit of controlling for relative performance within the mutual fund industry. Despite the fact that results reported in Tables 6-7 are weakly significant from a statistical view point; the difference of performances between ACC1 and ACC5 is always in favor of ACC1 (with the only exception of Q1 in Table 7).

Finally, in Table 8 we report the extra-performances obtained for the entire sample period 2004-2010. Here, we confirm the role of $A C C$ value in discriminating portfolios' performances, with lower values for the topological indicator signaling better investment allocations. This, in turn, supports the use of our proposed indicator as a complementary criterion than past- $\hat{\alpha}$ for building profitable investment strategies on a longer holding period, when markets experienced a boom and burst financial cycle. Furthermore, we note that results for the Core case confirm our findings on the profitability of the topbottom investment strategy. 
Table 6: Double Sorts Funds by Past Performances and $A C C$ - Pre Crisis. The table shows the resulting $5 \times 5$ portfolios' alphas obtained by sorting funds in quintiles firstly by past- $\hat{\alpha}$ performances and then by $A C C$. Panel $\mathrm{B}$ uses the core $A C C$ in which we drop those funds in the tails corresponding to both the top and bottom 5 per cent of the $A C C$ distribution in each $5 \times 5$ portfolio. The table reports the OLS estimates of each $5 \times 5$ portfolio's alpha (in percentage per year) and the corresponding absolute value of the t-statistics (in parentheses). Subscripts $3 f$ and $5 f$ stand for the three and five factors models used to compute alpha performances (Fama and French $(1993,2015)$ ). To compute past performance we use nine months of lookback period of daily observations on gross returns, which are determined by adding fund management fees to net returns. We then calculate the return of each quintile portfolio over the next three months using daily returns series and equally weighting funds in each $5 \times 5$ portfolio. $5 \times 5$ portfolios are redefined each quarter and the corresponding three months returns time series are connected across quarters to form a full sample period for each $5 \mathrm{x} 5$ portfolio. topbottom is the portfolio obtained investing long in funds belonging to the best-performer quintile portfolio and short funds in the worst-performer quintile, within the same quintile determined in the first sort. Finally, the portfolio denoted as Avg invests equally in each of the five top-bottom portfolios. The sample period is June 2004 to June 2007.

\begin{tabular}{|c|c|c|c|c|c|c|c|c|c|c|c|c|c|}
\hline \multirow[b]{2}{*}{$\begin{array}{l}\hat{\alpha}_{3 f} \rightarrow \\
\downarrow A C C\end{array}$} & \multirow[b]{2}{*}{ Q1 } & \multirow[b]{2}{*}{ Q2 } & \multirow[b]{2}{*}{ Q3 } & \multicolumn{7}{|c|}{ Panel A: Sort funds by past- $\hat{\alpha}$ and then by $A C C$} & \multirow[b]{2}{*}{ Q4 } & \multirow[b]{2}{*}{ Q5 } & \multirow[b]{2}{*}{ Avg } \\
\hline & & & & Q4 & Q5 & Avg & $\begin{array}{l}\hat{\alpha}_{5 f} \rightarrow \\
\downarrow A C C\end{array}$ & Q1 & Q2 & Q3 & & & \\
\hline $\mathrm{ACC} 1$ & $\begin{array}{c}5.26 \\
(1.56)\end{array}$ & $\begin{array}{c}4.81 \\
(2.29)\end{array}$ & $\begin{array}{l}4.66 \\
(2.27)\end{array}$ & $\begin{array}{c}5.78 \\
(2.81)\end{array}$ & $\begin{array}{l}17.10 \\
(3.21)\end{array}$ & $\begin{array}{c}7.52 \\
(2.43)\end{array}$ & $\mathrm{ACC} 1$ & $\begin{array}{c}4.37 \\
(1.33)\end{array}$ & $\begin{array}{l}2.81 \\
(1.60)\end{array}$ & $\begin{array}{c}4.37 \\
(2.39)\end{array}$ & $\begin{array}{c}5.92 \\
(3.03)\end{array}$ & $\begin{array}{l}17.98 \\
(3.33)\end{array}$ & $\begin{array}{c}7.09 \\
(2.34)\end{array}$ \\
\hline $\mathrm{ACC} 2$ & $\begin{array}{c}2.16 \\
(1.22)\end{array}$ & $\begin{array}{c}2.15 \\
(1.61)\end{array}$ & $\begin{array}{c}2.89 \\
(2.13)\end{array}$ & $\begin{array}{c}3.62 \\
(2.73)\end{array}$ & $\begin{array}{l}10.14 \\
(2.27)\end{array}$ & $\begin{array}{c}4.19 \\
(1.99)\end{array}$ & $\mathrm{ACC} 2$ & $\begin{array}{c}0.67 \\
(0.42)\end{array}$ & $\begin{array}{c}1.76 \\
(1.27)\end{array}$ & $\begin{array}{c}1.31 \\
(1.09)\end{array}$ & $\begin{array}{c}1.93 \\
(1.68)\end{array}$ & $\begin{array}{c}9.71 \\
(2.16)\end{array}$ & $\begin{array}{c}3.08 \\
(1.32)\end{array}$ \\
\hline ACC3 & $\begin{array}{c}2.46 \\
(1.12)\end{array}$ & $\begin{array}{c}2.49 \\
(2.01)\end{array}$ & $\begin{array}{l}3.28 \\
(2.77)\end{array}$ & $\begin{array}{c}3.32 \\
(2.56)\end{array}$ & $\begin{array}{c}8.65 \\
(2.30)\end{array}$ & $\begin{array}{c}4.04 \\
(2.15)\end{array}$ & $\mathrm{ACC} 3$ & $\begin{array}{c}1.68 \\
(0.92)\end{array}$ & $\begin{array}{l}1.86 \\
(1.62)\end{array}$ & $\begin{array}{c}2.79 \\
(2.59)\end{array}$ & $\begin{array}{c}3.28 \\
(2.59)\end{array}$ & $\begin{array}{c}9.42 \\
(2.51)\end{array}$ & $\begin{array}{c}3.81 \\
(2.05)\end{array}$ \\
\hline $\mathrm{ACC} 4$ & $\begin{array}{c}3.14 \\
(1.54)\end{array}$ & $\begin{array}{c}0.85 \\
(0.91)\end{array}$ & $\begin{array}{c}2.22 \\
(2.31)\end{array}$ & $\begin{array}{l}2.47 \\
(2.11)\end{array}$ & $\begin{array}{c}7.40 \\
(2.41)\end{array}$ & $\begin{array}{c}3.22 \\
(1.86)\end{array}$ & $\mathrm{ACC} 4$ & $\begin{array}{c}1.31 \\
(0.89)\end{array}$ & $\begin{array}{c}0.05 \\
(0.06)\end{array}$ & $\begin{array}{c}2.04 \\
(2.54)\end{array}$ & $\begin{array}{c}1.60 \\
(1.34)\end{array}$ & $\begin{array}{l}8.48 \\
(2.75)\end{array}$ & $\begin{array}{c}2.70 \\
(1.52)\end{array}$ \\
\hline ACC5 & $\begin{array}{c}-0.84 \\
(0.82)\end{array}$ & $\begin{array}{c}-0.42 \\
(0.62)\end{array}$ & $\begin{array}{c}0.34 \\
(0.57)\end{array}$ & $\begin{array}{c}0.64 \\
(0.96)\end{array}$ & $\begin{array}{c}3.73 \\
(1.68)\end{array}$ & $\begin{array}{c}0.69 \\
(0.35)\end{array}$ & ACC5 & $\begin{array}{l}-1.72 \\
(1.94)\end{array}$ & $\begin{array}{l}-0.75 \\
(1.15)\end{array}$ & $\begin{array}{c}0.33 \\
(0.56)\end{array}$ & $\begin{array}{c}0.86 \\
(1.30)\end{array}$ & $\begin{array}{c}5.51 \\
(2.25)\end{array}$ & $\begin{array}{c}0.84 \\
(0.21)\end{array}$ \\
\hline top-bottom & $\begin{array}{c}6.10 \\
(1.81)\end{array}$ & $\begin{array}{c}5.23 \\
(2.37)\end{array}$ & $\begin{array}{c}4.32 \\
(2.15)\end{array}$ & $\begin{array}{c}5.15 \\
(2.49)\end{array}$ & $\begin{array}{l}13.37 \\
(3.13)\end{array}$ & $\begin{array}{c}6.83 \\
(3.14)\end{array}$ & top-bottom & $\begin{array}{c}6.09 \\
(1.84)\end{array}$ & $\begin{array}{c}3.57 \\
(1.99)\end{array}$ & $\begin{array}{c}4.05 \\
(2.27)\end{array}$ & $\begin{array}{c}5.06 \\
(2.53)\end{array}$ & $\begin{array}{l}12.47 \\
(2.85)\end{array}$ & $\begin{array}{c}6.25 \\
(2.99)\end{array}$ \\
\hline
\end{tabular}

Panel B: Sort funds by past- $\hat{\alpha}$ and then by Core $A C C$

\begin{tabular}{|c|c|c|c|c|c|c|c|c|c|c|c|c|c|}
\hline $\begin{array}{l}\hat{\alpha}_{3 f} \rightarrow \\
\downarrow A C C\end{array}$ & Q1 & Q2 & Q3 & Q4 & Q5 & Avg & $\begin{array}{l}\hat{\alpha}_{5 f} \rightarrow \\
\downarrow A C C\end{array}$ & Q1 & Q2 & Q3 & Q4 & Q5 & Avg \\
\hline $\mathrm{ACC} 1$ & $\begin{array}{c}5.21 \\
(1.54)\end{array}$ & $\begin{array}{c}4.83 \\
(2.30)\end{array}$ & $\begin{array}{c}4.79 \\
(2.27)\end{array}$ & $\begin{array}{c}5.89 \\
(2.78)\end{array}$ & $\begin{array}{l}17.21 \\
(3.22)\end{array}$ & $\begin{array}{l}7.59 \\
(2.42)\end{array}$ & $\mathrm{ACC} 1$ & $\begin{array}{c}4.57 \\
(1.40)\end{array}$ & $\begin{array}{c}2.76 \\
(1.56)\end{array}$ & $\begin{array}{c}4.29 \\
(2.29)\end{array}$ & $\begin{array}{c}6.10 \\
(3.06)\end{array}$ & $\begin{array}{l}18.13 \\
(3.35)\end{array}$ & $\begin{array}{c}7.17 \\
(2.33)\end{array}$ \\
\hline $\mathrm{ACC} 2$ & $\begin{array}{c}2.09 \\
(1.20)\end{array}$ & $\begin{array}{c}2.11 \\
(1.59)\end{array}$ & $\begin{array}{c}3.09 \\
(2.29)\end{array}$ & $\begin{array}{c}3.64 \\
(2.76)\end{array}$ & $\begin{array}{l}10.32 \\
(2.32)\end{array}$ & $\begin{array}{c}4.25 \\
(2.03)\end{array}$ & $\mathrm{ACC} 2$ & $\begin{array}{c}0.90 \\
(0.58)\end{array}$ & $\begin{array}{c}1.66 \\
(1.21)\end{array}$ & $\begin{array}{c}1.24 \\
(1.01)\end{array}$ & $\begin{array}{c}2.03 \\
(1.76)\end{array}$ & $\begin{array}{c}9.38 \\
(2.10)\end{array}$ & $\begin{array}{c}3.04 \\
(1.33)\end{array}$ \\
\hline ACC3 & $\begin{array}{c}2.47 \\
(1.12)\end{array}$ & $\begin{array}{c}2.41 \\
(1.91)\end{array}$ & $\begin{array}{c}3.44 \\
(2.90)\end{array}$ & $\begin{array}{c}3.58 \\
(2.81)\end{array}$ & $\begin{array}{c}8.75 \\
(2.31)\end{array}$ & $\begin{array}{c}4.13 \\
(2.21)\end{array}$ & ACC3 & $\begin{array}{c}1.81 \\
(0.98)\end{array}$ & $\begin{array}{c}1.88 \\
(1.61)\end{array}$ & $\begin{array}{c}2.75 \\
(2.58)\end{array}$ & $\begin{array}{c}3.32 \\
(2.58)\end{array}$ & $\begin{array}{c}8.97 \\
(2.40)\end{array}$ & $\begin{array}{c}3.75 \\
(2.03)\end{array}$ \\
\hline $\mathrm{ACC} 4$ & $\begin{array}{c}3.26 \\
(1.59)\end{array}$ & $\begin{array}{c}0.63 \\
(0.67)\end{array}$ & $\begin{array}{c}2.19 \\
(2.26)\end{array}$ & $\begin{array}{c}2.52 \\
(2.13)\end{array}$ & $\begin{array}{c}7.38 \\
(2.38)\end{array}$ & $\begin{array}{c}3.20 \\
(1.81)\end{array}$ & $\mathrm{ACC} 4$ & $\begin{array}{c}1.35 \\
(0.91)\end{array}$ & $\begin{array}{c}0.04 \\
(0.05)\end{array}$ & $\begin{array}{c}2.02 \\
(2.47)\end{array}$ & $\begin{array}{c}1.44 \\
(1.19)\end{array}$ & $\begin{array}{c}8.27 \\
(2.70)\end{array}$ & $\begin{array}{c}2.62 \\
(1.47)\end{array}$ \\
\hline ACC5 & $\begin{array}{c}-0.86 \\
(0.86)\end{array}$ & $\begin{array}{c}-0.48 \\
(0.72)\end{array}$ & $\begin{array}{c}0.37 \\
(0.61)\end{array}$ & $\begin{array}{c}0.51 \\
(0.78)\end{array}$ & $\begin{array}{c}3.71 \\
(1.68)\end{array}$ & $\begin{array}{c}0.65 \\
(0.30)\end{array}$ & ACC5 & $\begin{array}{l}-1.81 \\
(2.03)\end{array}$ & $\begin{array}{l}-0.71 \\
(1.07)\end{array}$ & $\begin{array}{c}0.37 \\
(0.63)\end{array}$ & $\begin{array}{c}0.95 \\
(1.41)\end{array}$ & $\begin{array}{c}5.51 \\
(2.25)\end{array}$ & $\begin{array}{c}0.86 \\
(0.24)\end{array}$ \\
\hline top-bottom & $\begin{array}{c}6.08 \\
(1.78)\end{array}$ & $\begin{array}{c}5.31 \\
(2.43)\end{array}$ & $\begin{array}{c}4.42 \\
(2.14)\end{array}$ & $\begin{array}{c}5.38 \\
(2.53)\end{array}$ & $\begin{array}{l}13.50 \\
(3.14)\end{array}$ & $\begin{array}{c}6.94 \\
(2.40)\end{array}$ & top-bottom & $\begin{array}{c}6.38 \\
(1.93)\end{array}$ & $\begin{array}{c}3.48 \\
(1.93)\end{array}$ & $\begin{array}{c}3.92 \\
(2.15)\end{array}$ & $\begin{array}{c}5.15 \\
(2.53)\end{array}$ & $\begin{array}{l}12.63 \\
(2.87)\end{array}$ & $\begin{array}{c}6.31 \\
(2.28)\end{array}$ \\
\hline
\end{tabular}


Table 7: Double Sorts Funds by Past Performances and $A C C$ - Crisis. The table shows the resulting $5 \times 5$ portfolios' alphas obtained by sorting funds in quintiles firstly by past- $\hat{\alpha}$ performances and then by $A C C$. Panel $\mathrm{B}$ uses the core $A C C$ in which we drop those funds in the tails corresponding to both the top and bottom 5 per cent of the $A C C$ distribution in each $5 \times 5$ portfolio. The table reports the OLS estimates of each $5 \times 5$ portfolio's alpha (in percentage per year) and the corresponding absolute value of the t-statistics (in parentheses). Subscripts $3 f$ and $5 f$ stand for the three and five factors models used to compute alpha performances (Fama and French $(1993,2015)$ ). To compute past performance we use nine months of lookback period of daily observations on gross returns, which are determined by adding fund management fees to net returns. We then calculate the return of each quintile portfolio over the next three months using daily returns series and equally weighting funds in each $5 \times 5$ portfolio. $5 \times 5$ portfolios are redefined each quarter and the corresponding three months returns time series are connected across quarters to form a full sample period for each $5 \times 5$ portfolio. top-bottom is the portfolio obtained investing long in funds belonging to the best-performer quintile portfolio and short funds in the worst-performer quintile, within the same quintile determined in the first sort. Finally, the portfolio denoted as Avg invests equally in each of the five top-bottom portfolios. The sample period is September 2007 to June 2010.

\begin{tabular}{|c|c|c|c|c|c|c|c|c|c|c|c|c|c|}
\hline \multirow[b]{2}{*}{$\begin{array}{l}\hat{\alpha}_{3 f} \rightarrow \\
\downarrow A C C\end{array}$} & \multirow[b]{2}{*}{ Q1 } & \multirow[b]{2}{*}{ Q2 } & \multicolumn{10}{|c|}{ Panel A: Sort funds by past- $\hat{\alpha}$ and then by $A C C$} & \multirow[b]{2}{*}{ Avg } \\
\hline & & & Q3 & Q4 & Q5 & Avg & $\begin{array}{l}\hat{\alpha}_{5 f} \rightarrow \\
\downarrow A C C\end{array}$ & Q1 & Q2 & Q3 & Q4 & Q5 & \\
\hline $\mathrm{ACC} 1$ & $\begin{array}{c}-12.91 \\
(1.21)\end{array}$ & $\begin{array}{l}-4.93 \\
(0.89)\end{array}$ & $\begin{array}{l}-4.14 \\
(1.10)\end{array}$ & $\begin{array}{l}-4.96 \\
(1.21)\end{array}$ & $\begin{array}{l}-3.28 \\
(0.40)\end{array}$ & $\begin{array}{l}-6.04 \\
(0.96)\end{array}$ & $\mathrm{ACC} 1$ & $\begin{array}{c}-8.29 \\
(0.81)\end{array}$ & $\begin{array}{l}-3.34 \\
(0.56)\end{array}$ & $\begin{array}{l}-3.55 \\
(0.78)\end{array}$ & $\begin{array}{l}-2.42 \\
(0.63)\end{array}$ & $\begin{array}{l}-4.39 \\
(0.64)\end{array}$ & $\begin{array}{l}-4.40 \\
(0.68)\end{array}$ \\
\hline $\mathrm{ACC} 2$ & $\begin{array}{l}-8.82 \\
(0.96)\end{array}$ & $\begin{array}{l}-6.18 \\
(1.25)\end{array}$ & $\begin{array}{l}-3.67 \\
(1.11)\end{array}$ & $\begin{array}{l}-1.60 \\
(0.48)\end{array}$ & $\begin{array}{l}-1.04 \\
(0.19)\end{array}$ & $\begin{array}{c}-4.26 \\
(0.80)\end{array}$ & $\mathrm{ACC} 2$ & $\begin{array}{l}-9.25 \\
(1.14)\end{array}$ & $\begin{array}{l}-5.70 \\
(1.17)\end{array}$ & $\begin{array}{l}-2.96 \\
(0.94)\end{array}$ & $\begin{array}{l}-3.77 \\
(1.25)\end{array}$ & $\begin{array}{l}-1.29 \\
(0.25)\end{array}$ & $\begin{array}{l}-4.59 \\
(0.95)\end{array}$ \\
\hline $\mathrm{ACC} 3$ & $\begin{array}{l}-7.71 \\
(1.18)\end{array}$ & $\begin{array}{l}-5.53 \\
(1.39)\end{array}$ & $\begin{array}{l}-4.00 \\
(1.19)\end{array}$ & $\begin{array}{l}-5.00 \\
(1.27)\end{array}$ & $\begin{array}{l}-10.27 \\
(1.67)\end{array}$ & $\begin{array}{l}-6.50 \\
(1.34)\end{array}$ & $\mathrm{ACC} 3$ & $\begin{array}{r}-11.77 \\
(1.73)\end{array}$ & $\begin{array}{l}-4.88 \\
(1.16)\end{array}$ & $\begin{array}{l}-4.55 \\
(1.26)\end{array}$ & $\begin{array}{l}-5.34 \\
(1.42)\end{array}$ & $\begin{array}{l}-4.77 \\
(1.01)\end{array}$ & $\begin{array}{l}-6.26 \\
(1.32)\end{array}$ \\
\hline $\mathrm{ACC} 4$ & $\begin{array}{r}-12.55 \\
(2.03)\end{array}$ & $\begin{array}{l}-7.12 \\
(1.88)\end{array}$ & $\begin{array}{c}-6.09 \\
(1.89)\end{array}$ & $\begin{array}{l}-6.27 \\
(1.37)\end{array}$ & $\begin{array}{l}-5.03 \\
(0.85)\end{array}$ & $\begin{array}{l}-7.41 \\
(1.61)\end{array}$ & $\mathrm{ACC} 4$ & $\begin{array}{r}-10.65 \\
(1.77)\end{array}$ & $\begin{array}{l}-8.75 \\
(2.20)\end{array}$ & $\begin{array}{l}-5.63 \\
(1.58)\end{array}$ & $\begin{array}{l}-5.38 \\
(1.26)\end{array}$ & $\begin{array}{l}-1.97 \\
(0.40)\end{array}$ & $\begin{array}{l}-6.48 \\
(1.44)\end{array}$ \\
\hline ACC5 & $\begin{array}{r}-11.56 \\
(2.63)\end{array}$ & $\begin{array}{l}-6.64 \\
(1.88)\end{array}$ & $\begin{array}{l}-6.90 \\
(1.72)\end{array}$ & $\begin{array}{l}-5.80 \\
(1.50)\end{array}$ & $\begin{array}{l}-5.64 \\
(1.28)\end{array}$ & $\begin{array}{l}-7.31 \\
(1.80)\end{array}$ & ACC5 & $\begin{array}{r}-10.34 \\
(2.59)\end{array}$ & $\begin{array}{l}-8.27 \\
(2.13)\end{array}$ & $\begin{array}{l}-6.25 \\
(1.74)\end{array}$ & $\begin{array}{l}-6.66 \\
(1.62)\end{array}$ & $\begin{array}{l}-5.47 \\
(1.22)\end{array}$ & $\begin{array}{l}-7.40 \\
(1.86)\end{array}$ \\
\hline top-bottom & $\begin{array}{l}-1.35 \\
(0.13)\end{array}$ & $\begin{array}{l}1.71 \\
(0.33)\end{array}$ & $\begin{array}{c}2.76 \\
(0.70)\end{array}$ & $\begin{array}{c}0.84 \\
(0.20)\end{array}$ & $\begin{array}{c}2.37 \\
(0.30)\end{array}$ & $\begin{array}{c}1.27 \\
(0.26)\end{array}$ & top-bottom & $\begin{array}{c}2.05 \\
(0.21)\end{array}$ & $\begin{array}{c}4.93 \\
(0.88)\end{array}$ & $\begin{array}{c}2.69 \\
(0.63)\end{array}$ & $\begin{array}{c}4.24 \\
(1.00)\end{array}$ & $\begin{array}{c}1.08 \\
(0.15)\end{array}$ & $\begin{array}{c}3.00 \\
(0.60)\end{array}$ \\
\hline
\end{tabular}

Panel B: Sort funds by past- $\hat{\alpha}$ and then by Core $A C C$

\begin{tabular}{|c|c|c|c|c|c|c|c|c|c|c|c|c|c|}
\hline $\begin{array}{l}\hat{\alpha}_{3 f} \rightarrow \\
\downarrow A C C\end{array}$ & Q1 & Q2 & Q3 & Q4 & Q5 & Avg & $\begin{array}{l}\hat{\alpha}_{5 f} \rightarrow \\
\downarrow A C C\end{array}$ & Q1 & Q2 & Q3 & Q4 & Q5 & Avg \\
\hline $\mathrm{ACC} 1$ & $\begin{array}{r}-13.40 \\
(1.23)\end{array}$ & $\begin{array}{l}-4.50 \\
(0.80)\end{array}$ & $\begin{array}{l}-4.15 \\
(1.08)\end{array}$ & $\begin{array}{l}-5.08 \\
(1.22)\end{array}$ & $\begin{array}{l}-3.29 \\
(0.40)\end{array}$ & $\begin{array}{l}-6.08 \\
(0.95)\end{array}$ & $\mathrm{ACC} 1$ & $\begin{array}{l}-8.62 \\
(0.84)\end{array}$ & $\begin{array}{l}-2.98 \\
(0.49)\end{array}$ & $\begin{array}{l}-3.53 \\
(0.76)\end{array}$ & $\begin{array}{l}-2.13 \\
(0.54)\end{array}$ & $\begin{array}{l}-4.13 \\
(0.59)\end{array}$ & $\begin{array}{l}-4.28 \\
(0.64)\end{array}$ \\
\hline $\mathrm{ACC} 2$ & $\begin{array}{l}-8.44 \\
(0.91)\end{array}$ & $\begin{array}{c}-6.45 \\
(1.30)\end{array}$ & $\begin{array}{l}-4.12 \\
(1.23)\end{array}$ & $\begin{array}{l}-1.55 \\
(0.47)\end{array}$ & $\begin{array}{l}-1.25 \\
(0.22)\end{array}$ & $\begin{array}{c}-4.36 \\
(0.83)\end{array}$ & $\mathrm{ACC} 2$ & $\begin{array}{l}-9.25 \\
(1.15)\end{array}$ & $\begin{array}{c}-5.76 \\
(1.19)\end{array}$ & $\begin{array}{l}-2.76 \\
(0.89)\end{array}$ & $\begin{array}{l}-3.90 \\
(1.31)\end{array}$ & $\begin{array}{l}-1.37 \\
(0.27)\end{array}$ & $\begin{array}{l}-4.61 \\
(0.96)\end{array}$ \\
\hline $\mathrm{ACC} 3$ & $\begin{array}{l}-7.71 \\
(1.17)\end{array}$ & $\begin{array}{l}-5.77 \\
(1.43)\end{array}$ & $\begin{array}{l}-3.97 \\
(1.18)\end{array}$ & $\begin{array}{l}-4.96 \\
(1.26)\end{array}$ & $\begin{array}{r}-10.48 \\
(1.69)\end{array}$ & $\begin{array}{l}-6.58 \\
(1.35)\end{array}$ & ACC3 & $\begin{array}{r}-11.56 \\
(1.71)\end{array}$ & $\begin{array}{l}-4.81 \\
(1.14)\end{array}$ & $\begin{array}{l}-4.21 \\
(1.17)\end{array}$ & $\begin{array}{l}-5.34 \\
(1.42)\end{array}$ & $\begin{array}{l}-4.78 \\
(1.01)\end{array}$ & $\begin{array}{l}-6.14 \\
(1.29)\end{array}$ \\
\hline $\mathrm{ACC} 4$ & $\begin{array}{r}-12.38 \\
(2.03)\end{array}$ & $\begin{array}{c}-6.87 \\
(1.82)\end{array}$ & $\begin{array}{l}-6.29 \\
(1.91)\end{array}$ & $\begin{array}{c}-6.28 \\
(1.38)\end{array}$ & $\begin{array}{l}-4.95 \\
(0.84)\end{array}$ & $\begin{array}{l}-7.35 \\
(1.60)\end{array}$ & $\mathrm{ACC} 4$ & $\begin{array}{r}-10.16 \\
(1.68)\end{array}$ & $\begin{array}{l}-8.43 \\
(2.15)\end{array}$ & $\begin{array}{l}-5.44 \\
(1.51)\end{array}$ & $\begin{array}{l}-5.49 \\
(1.27)\end{array}$ & $\begin{array}{l}-1.91 \\
(0.39)\end{array}$ & $\begin{array}{c}-6.28 \\
(1.40)\end{array}$ \\
\hline ACC5 & $\begin{array}{l}-11.73 \\
(2.65)\end{array}$ & $\begin{array}{l}-6.74 \\
(1.89)\end{array}$ & $\begin{array}{l}-6.86 \\
(1.70)\end{array}$ & $\begin{array}{l}-5.41 \\
(1.41)\end{array}$ & $\begin{array}{l}-5.82 \\
(1.31)\end{array}$ & $\begin{array}{l}-7.31 \\
(1.79)\end{array}$ & ACC5 & $\begin{array}{r}-10.59 \\
(2.59)\end{array}$ & $\begin{array}{l}-8.23 \\
(2.08)\end{array}$ & $\begin{array}{l}-6.19 \\
(1.69)\end{array}$ & $\begin{array}{l}-6.52 \\
(1.60)\end{array}$ & $\begin{array}{l}-5.53 \\
(1.24)\end{array}$ & $\begin{array}{l}-7.41 \\
(1.84)\end{array}$ \\
\hline top-bottom & $\begin{array}{l}-1.67 \\
(0.15)\end{array}$ & $\begin{array}{c}2.24 \\
(0.42)\end{array}$ & $\begin{array}{c}2.71 \\
(0.66)\end{array}$ & $\begin{array}{c}0.33 \\
(0.08)\end{array}$ & $\begin{array}{c}2.53 \\
(0.31)\end{array}$ & $\begin{array}{c}1.23 \\
(0.26)\end{array}$ & top-bottom & $\begin{array}{c}1.97 \\
(0.20)\end{array}$ & $\begin{array}{c}5.25 \\
(0.90)\end{array}$ & $\begin{array}{c}2.66 \\
(0.61)\end{array}$ & $\begin{array}{c}4.39 \\
(1.00)\end{array}$ & $\begin{array}{c}1.40 \\
(0.19)\end{array}$ & $\begin{array}{c}3.14 \\
(0.58)\end{array}$ \\
\hline
\end{tabular}


Table 8: Double Sorts Funds by Past Performances and $A C C$. The table shows the resulting $5 \times 5$ ACCportfolios' alphas obtained by sorting funds in quintiles firstly by past- $\hat{\alpha}$ performances and then by $A C C$. Panel $\mathrm{B}$ uses the core $A C C$ in which we drop those funds in the tails corresponding to both the top and bottom 5 per cent of the $A C C$ distribution in each $5 \times 5$ portfolio. The table reports the OLS estimates of each $5 \times 5$ portfolio's alpha (in percentage per year) and the corresponding absolute value of the t-statistics (in parentheses). Subscripts $3 f$ and $5 f$ stand for the three and five factors models used to compute alpha performances (Fama and French $(1993,2015)$ ). To compute past performance we use nine months of lookback period of daily observations on gross returns, which are determined by adding fund management fees to net returns. We then calculate the return of each quintile portfolio over the next three months using daily returns series and equally weighting funds in each $5 \times 5$ portfolio. $5 \times 5$ portfolios are redefined each quarter and the corresponding three months returns time series are connected across quarters to form a full sample period for each $5 \times 5$ portfolio. top-bottom is the portfolio obtained investing long in funds belonging to the best-performer quintile portfolio and short funds in the worst-performer quintile, within the same quintile determined in the first sort. Finally, the portfolio denoted as Avg invests equally in each of the five top-bottom portfolios. The sample period is June 2004 to June 2010.

\begin{tabular}{|c|c|c|c|c|c|c|c|c|c|c|c|c|c|}
\hline \multirow[b]{2}{*}{$\begin{array}{l}\hat{\alpha}_{3 f} \rightarrow \\
\downarrow A C C\end{array}$} & \multirow[b]{2}{*}{ Q1 } & \multicolumn{12}{|c|}{ Panel A: Sort funds by past- $\hat{\alpha}$ and then by $A C C$} \\
\hline & & Q2 & Q3 & Q4 & Q5 & Avg & $\begin{array}{l}\hat{\alpha}_{5 f} \rightarrow \\
\downarrow A C C\end{array}$ & Q1 & Q2 & Q3 & Q4 & Q5 & Avg \\
\hline $\mathrm{ACC} 1$ & $\begin{array}{l}-0.89 \\
(0.16)\end{array}$ & $\begin{array}{c}1.41 \\
(0.49)\end{array}$ & $\begin{array}{l}0.97 \\
(0.47)\end{array}$ & $\begin{array}{c}0.78 \\
(0.35)\end{array}$ & $\begin{array}{c}6.85 \\
(1.41)\end{array}$ & $\begin{array}{c}1.82 \\
(0.51)\end{array}$ & $\mathrm{ACC} 1$ & $\begin{array}{c}0.43 \\
(0.08)\end{array}$ & $\begin{array}{c}0.91 \\
(0.30)\end{array}$ & $\begin{array}{c}1.33 \\
(0.55)\end{array}$ & $\begin{array}{c}2.06 \\
(0.99)\end{array}$ & $\begin{array}{c}7.06 \\
(1.59)\end{array}$ & $\begin{array}{c}2.36 \\
(0.70)\end{array}$ \\
\hline $\mathrm{ACC} 2$ & $\begin{array}{l}-2.30 \\
(0.51)\end{array}$ & $\begin{array}{l}-1.45 \\
(0.60)\end{array}$ & $\begin{array}{c}0.28 \\
(0.16)\end{array}$ & $\begin{array}{l}1.49 \\
(0.88)\end{array}$ & $\begin{array}{l}4.87 \\
(1.38)\end{array}$ & $\begin{array}{c}0.58 \\
(0.26)\end{array}$ & $\mathrm{ACC} 2$ & $\begin{array}{l}-3.27 \\
(0.83)\end{array}$ & $\begin{array}{l}-1.68 \\
(0.71)\end{array}$ & $\begin{array}{l}-0.51 \\
(0.32)\end{array}$ & $\begin{array}{l}-0.48 \\
(0.31)\end{array}$ & $\begin{array}{c}4.53 \\
(1.32)\end{array}$ & $\begin{array}{l}-0.28 \\
(0.17)\end{array}$ \\
\hline $\mathrm{ACC} 3$ & $\begin{array}{l}-2.11 \\
(0.65)\end{array}$ & $\begin{array}{l}-1.27 \\
(0.65)\end{array}$ & $\begin{array}{c}0.04 \\
(0.03)\end{array}$ & $\begin{array}{l}-0.15 \\
(0.07)\end{array}$ & $\begin{array}{c}0.09 \\
(0.03)\end{array}$ & $\begin{array}{l}-0.68 \\
(0.27)\end{array}$ & $\mathrm{ACC} 3$ & $\begin{array}{l}-4.25 \\
(1.30)\end{array}$ & $\begin{array}{l}-1.16 \\
(0.57)\end{array}$ & $\begin{array}{l}-0.55 \\
(0.32)\end{array}$ & $\begin{array}{l}-0.39 \\
(0.21)\end{array}$ & $\begin{array}{c}3.04 \\
(1.02)\end{array}$ & $\begin{array}{l}-0.66 \\
(0.28)\end{array}$ \\
\hline $\mathrm{ACC} 4$ & $\begin{array}{l}-4.61 \\
(1.50)\end{array}$ & $\begin{array}{l}-2.74 \\
(1.48)\end{array}$ & $\begin{array}{l}-1.43 \\
(0.91)\end{array}$ & $\begin{array}{l}-0.94 \\
(0.43)\end{array}$ & $\begin{array}{c}2.15 \\
(0.67)\end{array}$ & $\begin{array}{l}-1.51 \\
(0.73)\end{array}$ & $\mathrm{ACC} 4$ & $\begin{array}{l}-4.19 \\
(1.46)\end{array}$ & $\begin{array}{l}-3.78 \\
(2.00)\end{array}$ & $\begin{array}{l}-1.21 \\
(0.71)\end{array}$ & $\begin{array}{l}-1.22 \\
(0.59)\end{array}$ & $\begin{array}{c}4.19 \\
(1.49)\end{array}$ & $\begin{array}{l}-1.24 \\
(0.65)\end{array}$ \\
\hline ACC5 & $\begin{array}{l}-6.61 \\
(3.04)\end{array}$ & $\begin{array}{l}-3.32 \\
(1.94)\end{array}$ & $\begin{array}{l}-2.84 \\
(1.49)\end{array}$ & $\begin{array}{l}-1.84 \\
(1.00)\end{array}$ & $\begin{array}{c}-0.02 \\
(0.01)\end{array}$ & $\begin{array}{l}-2.93 \\
(1.49)\end{array}$ & $\mathrm{ACC} 5$ & $\begin{array}{l}-5.87 \\
(3.05)\end{array}$ & $\begin{array}{l}-3.96 \\
(2.15)\end{array}$ & $\begin{array}{l}-2.35 \\
(1.37)\end{array}$ & $\begin{array}{l}-2.10 \\
(1.08)\end{array}$ & $\begin{array}{c}1.37 \\
(0.55)\end{array}$ & $\begin{array}{l}-2.58 \\
(1.42)\end{array}$ \\
\hline top-bottom & $\begin{array}{c}5.72 \\
(1.04)\end{array}$ & $\begin{array}{c}4.73 \\
(1.68)\end{array}$ & $\begin{array}{c}3.81 \\
(1.74)\end{array}$ & $\begin{array}{c}2.62 \\
(1.13)\end{array}$ & $\begin{array}{l}6.87 \\
(1.52)\end{array}$ & $\begin{array}{c}4.75 \\
(1.87)\end{array}$ & top-bottom & $\begin{array}{c}6.30 \\
(1.22)\end{array}$ & $\begin{array}{l}4.87 \\
(1.67)\end{array}$ & $\begin{array}{c}3.67 \\
(1.59)\end{array}$ & $\begin{array}{c}4.15 \\
(1.81)\end{array}$ & $\begin{array}{c}5.69 \\
(1.32)\end{array}$ & $\begin{array}{c}4.94 \\
(1.89)\end{array}$ \\
\hline
\end{tabular}

Panel B: Sort funds by past- $\hat{\alpha}$ and then by Core $A C C$

\begin{tabular}{|c|c|c|c|c|c|c|c|c|c|c|c|c|c|}
\hline $\begin{array}{l}\hat{\alpha}_{3 f} \rightarrow \\
\downarrow A C C\end{array}$ & Q1 & Q2 & Q3 & Q4 & Q5 & Avg & $\begin{array}{l}\hat{\alpha}_{5 f} \rightarrow \\
\downarrow A C C\end{array}$ & Q1 & Q2 & Q3 & Q4 & Q5 & Avg \\
\hline $\mathrm{ACC} 1$ & $\begin{array}{l}-1.14 \\
(0.21)\end{array}$ & $\begin{array}{c}1.59 \\
(0.55)\end{array}$ & $\begin{array}{l}1.05 \\
(0.49)\end{array}$ & $\begin{array}{c}0.77 \\
(0.34)\end{array}$ & $\begin{array}{c}6.91 \\
(1.41)\end{array}$ & $\begin{array}{c}1.84 \\
(0.52)\end{array}$ & $\mathrm{ACC} 1$ & $\begin{array}{c}0.39 \\
(0.07)\end{array}$ & $\begin{array}{l}1.08 \\
(0.35)\end{array}$ & $\begin{array}{c}1.32 \\
(0.54)\end{array}$ & $\begin{array}{c}2.29 \\
(1.08)\end{array}$ & $\begin{array}{c}7.23 \\
(1.61)\end{array}$ & $\begin{array}{c}2.46 \\
(0.73)\end{array}$ \\
\hline $\mathrm{ACC} 2$ & $\begin{array}{l}-2.17 \\
(0.48)\end{array}$ & $\begin{array}{l}-1.60 \\
(0.66)\end{array}$ & $\begin{array}{c}0.16 \\
(0.09)\end{array}$ & $\begin{array}{c}1.52 \\
(0.90)\end{array}$ & $\begin{array}{c}4.92 \\
(1.39)\end{array}$ & $\begin{array}{c}0.57 \\
(0.25)\end{array}$ & $\mathrm{ACC} 2$ & $\begin{array}{l}-3.15 \\
(0.81)\end{array}$ & $\begin{array}{l}-1.81 \\
(0.77)\end{array}$ & $\begin{array}{l}-0.47 \\
(0.29)\end{array}$ & $\begin{array}{l}-0.48 \\
(0.32)\end{array}$ & $\begin{array}{c}4.34 \\
(1.28)\end{array}$ & $\begin{array}{c}-0.31 \\
(0.18)\end{array}$ \\
\hline ACC3 & $\begin{array}{l}-2.07 \\
(0.63)\end{array}$ & $\begin{array}{l}-1.43 \\
(0.73)\end{array}$ & $\begin{array}{c}0.15 \\
(0.09)\end{array}$ & $\begin{array}{l}-0.01 \\
(0.00)\end{array}$ & $\begin{array}{c}0.07 \\
(0.02)\end{array}$ & $\begin{array}{l}-0.66 \\
(0.25)\end{array}$ & ACC3 & $\begin{array}{l}-4.07 \\
(1.25)\end{array}$ & $\begin{array}{l}-1.12 \\
(0.55)\end{array}$ & $\begin{array}{l}-0.44 \\
(0.25)\end{array}$ & $\begin{array}{l}-0.38 \\
(0.20)\end{array}$ & $\begin{array}{c}2.80 \\
(0.94)\end{array}$ & $\begin{array}{l}-0.64 \\
(0.26)\end{array}$ \\
\hline $\mathrm{ACC} 4$ & $\begin{array}{l}-4.41 \\
(1.45)\end{array}$ & $\begin{array}{l}-2.73 \\
(1.47)\end{array}$ & $\begin{array}{l}-1.51 \\
(0.94)\end{array}$ & $\begin{array}{l}-0.90 \\
(0.41)\end{array}$ & $\begin{array}{c}2.17 \\
(0.68)\end{array}$ & $\begin{array}{l}-1.48 \\
(0.72)\end{array}$ & $\mathrm{ACC} 4$ & $\begin{array}{l}-3.96 \\
(1.38)\end{array}$ & $\begin{array}{l}-3.61 \\
(1.94)\end{array}$ & $\begin{array}{l}-1.13 \\
(0.66)\end{array}$ & $\begin{array}{l}-1.36 \\
(0.65)\end{array}$ & $\begin{array}{c}4.10 \\
(1.47)\end{array}$ & $\begin{array}{c}-1.19 \\
(0.63)\end{array}$ \\
\hline ACC5 & $\begin{array}{l}-6.69 \\
(3.06)\end{array}$ & $\begin{array}{l}-3.38 \\
(1.96)\end{array}$ & $\begin{array}{l}-2.79 \\
(1.46)\end{array}$ & $\begin{array}{l}-1.73 \\
(0.95)\end{array}$ & $\begin{array}{l}-0.09 \\
(0.04)\end{array}$ & $\begin{array}{l}-2.94 \\
(1.49)\end{array}$ & ACC5 & $\begin{array}{l}-6.05 \\
(3.08)\end{array}$ & $\begin{array}{l}-3.92 \\
(2.09)\end{array}$ & $\begin{array}{l}-2.31 \\
(1.32)\end{array}$ & $\begin{array}{l}-1.98 \\
(1.03)\end{array}$ & $\begin{array}{c}1.35 \\
(0.54)\end{array}$ & $\begin{array}{l}-2.58 \\
(1.39)\end{array}$ \\
\hline top-bottom & $\begin{array}{c}5.55 \\
(1.00)\end{array}$ & $\begin{array}{c}4.98 \\
(1.74)\end{array}$ & $\begin{array}{c}3.84 \\
(1.70)\end{array}$ & $\begin{array}{c}2.51 \\
(1.06)\end{array}$ & $\begin{array}{c}7.00 \\
(1.53)\end{array}$ & $\begin{array}{c}4.77 \\
(1.41)\end{array}$ & top-bottom & $\begin{array}{c}6.44 \\
(1.24)\end{array}$ & $\begin{array}{c}5.00 \\
(1.67)\end{array}$ & $\begin{array}{c}3.63 \\
(1.54)\end{array}$ & $\begin{array}{c}4.27 \\
(1.81)\end{array}$ & $\begin{array}{c}5.88 \\
(1.35)\end{array}$ & $\begin{array}{c}5.04 \\
(1.52)\end{array}$ \\
\hline
\end{tabular}




\subsection{Reverse Sorts}

Findings from Tables 6-8 indicate that on average higher values of specialization (low $A C C$ value) produce better extra-performances, although this relationship is influenced by both the quintiles chosen in the first sort and the impact of the crisis of mid-2007. For this reason we also analyze whether information about funds' future performances is contained in past- $\hat{\alpha}$ and not in the $A C C$ distribution. Hence, we sort funds in quintile in reverse, i.e. firstly by the $A C C$ and then by past- $\hat{\alpha}$, and we report in Tables $9-11$ the resulting $5 \times 5$ portfolios as well as the $A v g$ and top-bottom strategies for different time windows.

The average difference between top-bottom portfolios prior to the crisis is very significant and above 7 per cent in both the three and five factors models (see Table 9). This means that past- $\hat{\alpha}$ sort adds incremental information about future funds performances beyond the $A C C$ index especially for those less common portfolios (namely, those in ACC1). Hence, prior to the crisis of mid-2007, double-sorting funds according to the $A C C$ index and then past- $\hat{\alpha}$ produces $5 \times 5$ quintile portfolios' extra-performances on average comparable with those obtained applying the opposite double-sorts criterion. By contrast, for observations in the interval 2007-2010 we note in Table 10 that sorting firstly by the $A C C$ index and then by past- $\hat{\alpha}$ determines higher performances than the opposite case (see Table 7). During the outbreak of financial markets, therefore, persistence in past- $\hat{\alpha}$ seems to have driven better quintile extra-performances than the $A C C$ property. These results are supported also by the enlarged time window from 2004 to 2010 (see Table 11). Once again by combing information from both past- $\hat{\alpha}$ and $A C C$, investors can benefit from the investment strategy long in the top double-sort quintile and short in the bottom one, thus supporting the use of the proposed topological indicator as a complementary information that can be exploited to build portfolios. These results are largely confirmed by the Core cases (see panels B in Tables 9-11). 
Table 9: Reverse Double Sorts Funds by $A C C$ and Past Performances - Pre Crisis. The table shows in Panel A the resulting $5 \times 5$ portfolios' alphas obtained by sorting funds in quintiles firstly by $A C C$ and then by past- $\hat{\alpha}$ performances. Panel B uses the core $A C C$ in which we drop those funds in the tails corresponding to both the top and bottom 5 per cent of the $A C C$ distribution in each $5 \times 5$ portfolio. The table reports the OLS estimates of each $5 \times 5$ portfolio's alpha (in percentage per year) and the corresponding absolute value of the t-statistics (in parentheses). Subscripts $3 f$ and $5 f$ stand for the three and five factors models used to compute alpha performances (Fama and French (1993, 2015)). To compute past performance we use nine months of lookback period of daily observations on gross returns, which are determined by adding fund management fees to net returns. We then calculate the return of each quintile portfolio over the next three months using daily returns series and equally weighting funds in each $5 \times 5$ portfolio. $5 \times 5$ portfolios are redefined each quarter and the corresponding three months returns time series are connected across quarters to form a full sample period for each $5 \times 5$ portfolio. top-bottom is the portfolio obtained investing long in funds belonging to the best-performer quintile portfolio and short funds in the worst-performer quintile, within the same quintile determined in the first sort. Finally, the portfolio denoted as Avg invests equally in each of the five top-bottom portfolios. The sample period is June 2004 to June 2007.

Panel A: Sorting funds by $A C C$ and then by past- $\hat{\alpha}$

\begin{tabular}{|c|c|c|c|c|c|c|c|c|c|c|c|c|c|}
\hline $\begin{array}{l}A C C \rightarrow \\
\downarrow \hat{\alpha}_{3 f}\end{array}$ & $\mathrm{ACC} 1$ & $\mathrm{ACC} 2$ & ACC3 & ACC4 & ACC5 & Avg & $\begin{array}{l}A C C \rightarrow \\
\downarrow \hat{\alpha}_{5 f}\end{array}$ & $\mathrm{ACC} 1$ & $\mathrm{ACC} 2$ & ACC3 & $\mathrm{ACC} 4$ & ACC5 & Avg \\
\hline Q1 & $\begin{array}{c}3.88 \\
(1.77)\end{array}$ & $\begin{array}{c}3.44 \\
(1.51)\end{array}$ & $\begin{array}{c}1.74 \\
(1.44)\end{array}$ & $\begin{array}{l}-0.16 \\
(0.11)\end{array}$ & $\begin{array}{l}-0.93 \\
(0.93)\end{array}$ & $\begin{array}{c}1.59 \\
(0.74)\end{array}$ & Q1 & $\begin{array}{c}3.25 \\
(1.51)\end{array}$ & $\begin{array}{c}2.70 \\
(1.22)\end{array}$ & $\begin{array}{c}1.31 \\
(1.12)\end{array}$ & $\begin{array}{l}-0.53 \\
(0.36)\end{array}$ & $\begin{array}{l}-1.04 \\
(1.08)\end{array}$ & $\begin{array}{c}1.14 \\
(0.48)\end{array}$ \\
\hline Q2 & $\begin{array}{c}6.25 \\
(2.42)\end{array}$ & $\begin{array}{c}0.94 \\
(0.89)\end{array}$ & $\begin{array}{c}0.81 \\
(1.03)\end{array}$ & $\begin{array}{c}0.54 \\
(0.63)\end{array}$ & $\begin{array}{l}-0.64 \\
(0.84)\end{array}$ & $\begin{array}{c}1.58 \\
(0.83)\end{array}$ & Q2 & $\begin{array}{c}6.01 \\
(2.33)\end{array}$ & $\begin{array}{c}0.56 \\
(0.55)\end{array}$ & $\begin{array}{c}0.70 \\
(0.89)\end{array}$ & $\begin{array}{c}0.30 \\
(0.36)\end{array}$ & $\begin{array}{l}-0.73 \\
(0.99)\end{array}$ & $\begin{array}{c}1.37 \\
(0.63)\end{array}$ \\
\hline Q3 & $\begin{array}{c}7.29 \\
(2.11)\end{array}$ & $\begin{array}{c}3.08 \\
(3.47)\end{array}$ & $\begin{array}{c}2.04 \\
(2.46)\end{array}$ & $\begin{array}{c}1.73 \\
(2.12)\end{array}$ & $\begin{array}{l}-0.11 \\
(0.15)\end{array}$ & $\begin{array}{c}2.81 \\
(2.00)\end{array}$ & Q3 & $\begin{array}{c}7.11 \\
(2.05)\end{array}$ & $\begin{array}{c}2.84 \\
(3.28)\end{array}$ & $\begin{array}{c}1.79 \\
(2.20)\end{array}$ & $\begin{array}{c}1.52 \\
(1.92)\end{array}$ & $\begin{array}{l}-0.14 \\
(0.20)\end{array}$ & $\begin{array}{c}2.62 \\
(1.85)\end{array}$ \\
\hline Q4 & $\begin{array}{c}8.86 \\
(2.23)\end{array}$ & $\begin{array}{c}3.72 \\
(3.12)\end{array}$ & $\begin{array}{c}1.07 \\
(1.33)\end{array}$ & $\begin{array}{c}2.17 \\
(2.58)\end{array}$ & $\begin{array}{c}0.98 \\
(1.27)\end{array}$ & $\begin{array}{c}3.36 \\
(2.11)\end{array}$ & Q4 & $\begin{array}{c}8.69 \\
(2.18)\end{array}$ & $\begin{array}{c}3.48 \\
(2.94)\end{array}$ & $\begin{array}{c}0.94 \\
(1.19)\end{array}$ & $\begin{array}{c}1.93 \\
(2.35)\end{array}$ & $\begin{array}{c}0.87 \\
(1.16)\end{array}$ & $\begin{array}{c}3.18 \\
(1.97)\end{array}$ \\
\hline Q5 & $\begin{array}{l}16.73 \\
(3.17)\end{array}$ & $\begin{array}{c}9.66 \\
(3.05)\end{array}$ & $\begin{array}{c}6.87 \\
(2.99)\end{array}$ & $\begin{array}{c}5.91 \\
(2.87)\end{array}$ & $\begin{array}{c}5.44 \\
(2.61)\end{array}$ & $\begin{array}{c}8.92 \\
(2.94)\end{array}$ & Q5 & $\begin{array}{l}16.20 \\
(3.07)\end{array}$ & $\begin{array}{c}9.15 \\
(2.92)\end{array}$ & $\begin{array}{c}6.47 \\
(2.87)\end{array}$ & $\begin{array}{c}5.55 \\
(2.75)\end{array}$ & $\begin{array}{c}5.11 \\
(2.48)\end{array}$ & $\begin{array}{c}8.50 \\
(2.82)\end{array}$ \\
\hline top-bottom & $\begin{array}{l}12.86 \\
(2.82)\end{array}$ & $\begin{array}{c}6.21 \\
(1.72)\end{array}$ & $\begin{array}{c}5.13 \\
(2.25)\end{array}$ & $\begin{array}{c}6.08 \\
(2.58)\end{array}$ & $\begin{array}{c}6.37 \\
(2.65)\end{array}$ & $\begin{array}{c}7.33 \\
(2.79)\end{array}$ & top-bottom & $\begin{array}{l}12.95 \\
(2.84)\end{array}$ & $\begin{array}{c}6.44 \\
(1.80)\end{array}$ & $\begin{array}{c}5.16 \\
(2.29)\end{array}$ & $\begin{array}{c}6.08 \\
(2.59)\end{array}$ & $\begin{array}{c}6.15 \\
(2.57)\end{array}$ & $\begin{array}{c}7.36 \\
(2.81)\end{array}$ \\
\hline
\end{tabular}

Panel B: Sorting funds by Core $A C C$ and then by past- $\hat{\alpha}$

$A C C \rightarrow \quad$ ACC1 1 ACC2 $\quad$ ACC3 $\quad$ ACC4 ACC5 Avg $\quad$ ACC $\rightarrow \quad$ ACC1 $\quad$ ACC2 $\quad$ ACC3 $\quad$ ACC4 ACC5 $\quad$ Avg

$\downarrow \hat{\alpha}_{3 f} \quad \downarrow \hat{\alpha}_{5 f}$

\begin{tabular}{|c|c|c|c|c|c|c|c|c|c|c|c|c|c|}
\hline Q1 & $\begin{array}{c}-0.04 \\
(0.03)\end{array}$ & $\begin{array}{c}3.07 \\
(1.33)\end{array}$ & $\begin{array}{c}2.22 \\
(1.75)\end{array}$ & $\begin{array}{c}-0.04 \\
(0.03)\end{array}$ & $\begin{array}{c}-1.08 \\
(1.00)\end{array}$ & $\begin{array}{c}0.83 \\
(0.41)\end{array}$ & Q1 & $\begin{array}{c}-0.42 \\
(0.28)\end{array}$ & $\begin{array}{c}2.35 \\
(1.05)\end{array}$ & $\begin{array}{c}1.80 \\
(1.46)\end{array}$ & $\begin{array}{c}-0.42 \\
(0.28)\end{array}$ & $\begin{array}{c}-1.15 \\
(1.10)\end{array}$ & $\begin{array}{c}0.43 \\
(0.17)\end{array}$ \\
\hline Q2 & $\begin{array}{c}0.15 \\
(0.17)\end{array}$ & $\begin{array}{c}1.17 \\
(1.09)\end{array}$ & $\begin{array}{c}0.55 \\
(0.65)\end{array}$ & $\begin{array}{c}0.15 \\
(0.17)\end{array}$ & $\begin{array}{c}-0.52 \\
(0.62)\end{array}$ & $\begin{array}{c}0.30 \\
(0.29)\end{array}$ & Q2 & $\begin{array}{c}-0.09 \\
(0.10)\end{array}$ & $\begin{array}{c}0.83 \\
(0.79)\end{array}$ & $\begin{array}{c}0.44 \\
(0.53)\end{array}$ & $\begin{array}{c}-0.09 \\
(0.10)\end{array}$ & $\begin{array}{c}-0.65 \\
(0.80)\end{array}$ & $\begin{array}{c}0.09 \\
(0.06)\end{array}$ \\
\hline Q3 & $\begin{array}{c}1.64 \\
(1.95)\end{array}$ & $\begin{array}{c}3.55 \\
(3.79)\end{array}$ & $\begin{array}{c}1.75 \\
(2.16)\end{array}$ & $\begin{array}{c}1.64 \\
(1.95)\end{array}$ & $\begin{array}{c}-0.40 \\
(0.55)\end{array}$ & $\begin{array}{c}1.63 \\
(1.86)\end{array}$ & Q3 & $\begin{array}{c}1.44 \\
(1.78)\end{array}$ & $\begin{array}{c}3.32 \\
(3.63)\end{array}$ & $\begin{array}{c}1.50 \\
(1.89)\end{array}$ & $\begin{array}{c}1.44 \\
(1.78)\end{array}$ & $\begin{array}{c}-0.42 \\
(0.58)\end{array}$ & $\begin{array}{c}1.46 \\
(1.70)\end{array}$ \\
\hline Q4 & $\begin{array}{c}2.33 \\
(2.59)\end{array}$ & $\begin{array}{c}3.51 \\
(3.09)\end{array}$ & $\begin{array}{c}1.23 \\
(1.45)\end{array}$ & $\begin{array}{c}2.33 \\
(2.59)\end{array}$ & $\begin{array}{c}0.58 \\
(0.74)\end{array}$ & $\begin{array}{c}1.99 \\
(2.09)\end{array}$ & Q4 & $\begin{array}{c}2.02 \\
(2.33)\end{array}$ & $\begin{array}{c}3.30 \\
(2.93)\end{array}$ & $\begin{array}{c}1.07 \\
(1.28)\end{array}$ & $\begin{array}{c}2.02 \\
(2.33)\end{array}$ & $\begin{array}{c}0.50 \\
(0.66)\end{array}$ & $\begin{array}{c}1.78 \\
(1.90)\end{array}$ \\
\hline Q5 & $\begin{array}{c}5.77 \\
(2.71)\end{array}$ & $\begin{array}{l}10.38 \\
(2.83)\end{array}$ & $\begin{array}{c}7.38 \\
(2.28)\end{array}$ & $\begin{array}{c}5.77 \\
(2.71)\end{array}$ & $\begin{array}{c}4.69 \\
(2.46)\end{array}$ & $\begin{array}{c}6.80 \\
(2.60)\end{array}$ & Q5 & $\begin{array}{c}5.46 \\
(2.61)\end{array}$ & $\begin{array}{c}9.83 \\
(2.70)\end{array}$ & $\begin{array}{c}6.76 \\
(2.11)\end{array}$ & $\begin{array}{c}5.46 \\
(2.61)\end{array}$ & $\begin{array}{c}4.44 \\
(2.36)\end{array}$ & $\begin{array}{c}6.39 \\
(2.48)\end{array}$ \\
\hline top-bottom & $\begin{array}{c}5.81 \\
(2.37)\end{array}$ & $\begin{array}{c}7.32 \\
(1.81)\end{array}$ & $\begin{array}{c}5.16 \\
(1.64)\end{array}$ & $\begin{array}{c}5.81 \\
(2.37)\end{array}$ & $\begin{array}{c}5.77 \\
(2.56)\end{array}$ & $\begin{array}{c}5.97 \\
(2.15)\end{array}$ & top-bottom & $\begin{array}{c}5.88 \\
(2.40)\end{array}$ & $\begin{array}{c}7.48 \\
(1.86)\end{array}$ & $\begin{array}{c}4.95 \\
(1.57)\end{array}$ & $\begin{array}{c}5.88 \\
(2.40)\end{array}$ & $\begin{array}{c}5.59 \\
(2.49)\end{array}$ & $\begin{array}{c}5.96 \\
(2.14)\end{array}$ \\
\hline
\end{tabular}


Table 10: Reverse Double Sorts Funds by $A C C$ and Past Performances - Crisis. The table shows in Panel A the resulting $5 \times 5$ portfolios' alphas obtained by sorting funds in quintiles firstly by $A C C$ and then by past- $\hat{\alpha}$ performances. Panel B uses the core $A C C$ in which we drop those funds in the tails corresponding to both the top and bottom 5 per cent of the $A C C$ distribution in each 5x5 portfolio. The table reports the OLS estimates of each 5x5 portfolio's alpha (in percentage per year) and the corresponding absolute value of the t-statistics (in parentheses). Subscripts $3 f$ and $5 f$ stand for the three and five factors models used to compute alpha performances (Fama and French (1993, 2015)). To compute past performance we use nine months of lookback period of daily observations on gross returns, which are determined by adding fund management fees to net returns. We then calculate the return of each quintile portfolio over the next three months using daily returns series and equally weighting funds in each $5 \times 5$ portfolio. $5 \times 5$ portfolios are redefined each quarter and the corresponding three months returns time series are connected across quarters to form a full sample period for each $5 \times 5$ portfolio. top-bottom is the portfolio obtained investing long in funds belonging to the best-performer quintile portfolio and short funds in the worst-performer quintile, within the same quintile determined in the first sort. Finally, the portfolio denoted as Avg invests equally in each of the five top-bottom portfolios. The sample period is September 2007 to June 2010.

Panel A: Sorting funds by $A C C$ and then by past- $\hat{\alpha}$

\begin{tabular}{|c|c|c|c|c|c|c|c|c|c|c|c|c|c|}
\hline $\begin{array}{l}A C C \rightarrow \\
\downarrow \hat{\alpha}_{3 f}\end{array}$ & ACC1 & $\mathrm{ACC} 2$ & ACC3 & $\mathrm{ACC} 4$ & ACC5 & Avg & $\begin{array}{l}A C C \rightarrow \\
\downarrow \hat{\alpha}_{5 f}\end{array}$ & $\mathrm{ACC} 1$ & $\mathrm{ACC} 2$ & ACC3 & $\mathrm{ACC} 4$ & ACC5 & Avg \\
\hline Q1 & $\begin{array}{l}-13.38 \\
(1.85)\end{array}$ & $\begin{array}{c}-13.89 \\
(2.20)\end{array}$ & $\begin{array}{l}-13.57 \\
(2.63)\end{array}$ & $\begin{array}{c}-13.79 \\
(2.82)\end{array}$ & $\begin{array}{l}-10.98 \\
(1.50)\end{array}$ & $\begin{array}{c}-13.12 \\
(2.20)\end{array}$ & Q1 & $\begin{array}{l}-10.78 \\
(1.50)\end{array}$ & $\begin{array}{l}-12.56 \\
(2.00)\end{array}$ & $\begin{array}{l}-12.17 \\
(2.39)\end{array}$ & $\begin{array}{l}-12.42 \\
(2.63)\end{array}$ & $\begin{array}{c}-9.16 \\
(1.25)\end{array}$ & $\begin{array}{r}-11.42 \\
(1.95)\end{array}$ \\
\hline Q2 & $\begin{array}{l}-7.36 \\
(1.07)\end{array}$ & $\begin{array}{l}-4.01 \\
(1.09)\end{array}$ & $\begin{array}{l}-7.91 \\
(2.07)\end{array}$ & $\begin{array}{l}-7.75 \\
(2.05)\end{array}$ & $\begin{array}{l}-7.29 \\
(2.10)\end{array}$ & $\begin{array}{c}-6.86 \\
(1.68)\end{array}$ & Q2 & $\begin{array}{l}-6.52 \\
(0.95)\end{array}$ & $\begin{array}{c}-3.70 \\
(1.02)\end{array}$ & $\begin{array}{l}-7.43 \\
(1.97)\end{array}$ & $\begin{array}{l}-7.15 \\
(1.91)\end{array}$ & $\begin{array}{l}-7.02 \\
(2.05)\end{array}$ & $\begin{array}{c}-6.37 \\
(1.58)\end{array}$ \\
\hline Q3 & $\begin{array}{l}-8.46 \\
(1.19)\end{array}$ & $\begin{array}{l}-4.01 \\
(1.19)\end{array}$ & $\begin{array}{c}-5.34 \\
(1.64)\end{array}$ & $\begin{array}{l}-7.80 \\
(2.13)\end{array}$ & $\begin{array}{c}-4.62 \\
(1.37)\end{array}$ & $\begin{array}{c}-6.05 \\
(1.51)\end{array}$ & Q3 & $\begin{array}{l}-7.39 \\
(1.04)\end{array}$ & $\begin{array}{l}-4.00 \\
(1.19)\end{array}$ & $\begin{array}{l}-5.21 \\
(1.63)\end{array}$ & $\begin{array}{l}-7.38 \\
(2.04)\end{array}$ & $\begin{array}{c}-4.79 \\
(1.44)\end{array}$ & $\begin{array}{l}-5.75 \\
(1.47)\end{array}$ \\
\hline Q4 & $\begin{array}{l}-4.17 \\
(0.77)\end{array}$ & $\begin{array}{c}-3.99 \\
(1.31)\end{array}$ & $\begin{array}{c}-5.80 \\
(1.63)\end{array}$ & $\begin{array}{l}-5.74 \\
(1.67)\end{array}$ & $\begin{array}{c}-5.37 \\
(1.33)\end{array}$ & $\begin{array}{c}-5.01 \\
(1.34)\end{array}$ & Q4 & $\begin{array}{l}-3.75 \\
(0.70)\end{array}$ & $\begin{array}{c}-3.81 \\
(1.28)\end{array}$ & $\begin{array}{c}-5.49 \\
(1.56)\end{array}$ & $\begin{array}{l}-5.83 \\
(1.74)\end{array}$ & $\begin{array}{c}-5.52 \\
(1.37)\end{array}$ & $\begin{array}{l}-4.88 \\
(1.33)\end{array}$ \\
\hline Q5 & $\begin{array}{l}-4.11 \\
(0.66)\end{array}$ & $\begin{array}{l}-1.84 \\
(0.39)\end{array}$ & $\begin{array}{c}-3.02 \\
(0.68)\end{array}$ & $\begin{array}{l}-1.42 \\
(0.31)\end{array}$ & $\begin{array}{c}-4.92 \\
(1.21)\end{array}$ & $\begin{array}{l}-3.06 \\
(0.65)\end{array}$ & Q5 & $\begin{array}{l}-3.58 \\
(0.58)\end{array}$ & $\begin{array}{l}-2.61 \\
(0.57)\end{array}$ & $\begin{array}{l}-3.47 \\
(0.81)\end{array}$ & $\begin{array}{l}-2.43 \\
(0.58)\end{array}$ & $\begin{array}{c}-6.21 \\
(1.66)\end{array}$ & $\begin{array}{l}-3.66 \\
(0.84)\end{array}$ \\
\hline top-bottom & $\begin{array}{c}9.27 \\
(1.40)\end{array}$ & $\begin{array}{l}12.06 \\
(1.90)\end{array}$ & $\begin{array}{l}10.55 \\
(2.16)\end{array}$ & $\begin{array}{l}12.38 \\
(2.58)\end{array}$ & $\begin{array}{c}6.06 \\
(0.71)\end{array}$ & $\begin{array}{l}10.06 \\
(1.75)\end{array}$ & top-bottom & $\begin{array}{c}7.20 \\
(1.09)\end{array}$ & $\begin{array}{c}9.95 \\
(1.57)\end{array}$ & $\begin{array}{c}8.70 \\
(1.80)\end{array}$ & $\begin{array}{c}9.99 \\
(2.11)\end{array}$ & $\begin{array}{c}2.95 \\
(0.35)\end{array}$ & $\begin{array}{c}7.76 \\
(1.52)\end{array}$ \\
\hline
\end{tabular}

Panel B: Sorting funds by Core $A C C$ and then by past- $\hat{\alpha}$

$A C C \rightarrow \quad$ ACC1 1 ACC2 $\quad$ ACC3 $\quad$ ACC4 ACC5 Avg $\quad$ ACC $\rightarrow \quad$ ACC1 ACC2 $\quad$ ACC3 $\quad$ ACC4 ACC5 Avg

$\downarrow \hat{\alpha}_{3 f} \quad \downarrow \hat{\alpha}_{5 f}$

\begin{tabular}{|c|c|c|c|c|c|c|c|c|c|c|c|c|c|}
\hline Q1 & $\begin{array}{l}-13.35 \\
(2.72)\end{array}$ & $\begin{array}{c}-12.52 \\
(2.05)\end{array}$ & $\begin{array}{l}-13.27 \\
(2.62)\end{array}$ & $\begin{array}{l}-13.35 \\
(2.72)\end{array}$ & $\begin{array}{l}-11.15 \\
(1.54)\end{array}$ & $\begin{array}{l}-12.73 \\
(2.33)\end{array}$ & Q1 & $\begin{array}{r}-12.10 \\
(2.55)\end{array}$ & $\begin{array}{c}-11.24 \\
(1.86)\end{array}$ & $\begin{array}{r}-11.92 \\
(2.38)\end{array}$ & $\begin{array}{l}-12.10 \\
(2.55)\end{array}$ & $\begin{array}{c}-9.28 \\
(1.28)\end{array}$ & $\begin{array}{r}-11.33 \\
(2.12)\end{array}$ \\
\hline Q2 & $\begin{array}{c}-7.69 \\
(1.98)\end{array}$ & $\begin{array}{c}-3.77 \\
(1.08)\end{array}$ & $\begin{array}{c}-7.83 \\
(1.97)\end{array}$ & $\begin{array}{c}-7.69 \\
(1.98)\end{array}$ & $\begin{array}{l}-7.76 \\
(2.24)\end{array}$ & $\begin{array}{c}-6.95 \\
(1.85)\end{array}$ & Q2 & $\begin{array}{l}-7.02 \\
(1.83)\end{array}$ & $\begin{array}{c}-3.46 \\
(1.00)\end{array}$ & $\begin{array}{c}-7.43 \\
(1.89)\end{array}$ & $\begin{array}{c}-7.02 \\
(1.83)\end{array}$ & $\begin{array}{l}-7.47 \\
(2.18)\end{array}$ & $\begin{array}{c}-6.48 \\
(1.75)\end{array}$ \\
\hline Q3 & $\begin{array}{l}-7.38 \\
(2.15)\end{array}$ & $\begin{array}{c}-5.23 \\
(1.53)\end{array}$ & $\begin{array}{c}-5.94 \\
(1.74)\end{array}$ & $\begin{array}{l}-7.38 \\
(2.15)\end{array}$ & $\begin{array}{c}-5.28 \\
(1.50)\end{array}$ & $\begin{array}{c}-6.24 \\
(1.81)\end{array}$ & Q3 & $\begin{array}{c}-6.86 \\
(2.03)\end{array}$ & $\begin{array}{c}-5.27 \\
(1.55)\end{array}$ & $\begin{array}{c}-5.76 \\
(1.71)\end{array}$ & $\begin{array}{l}-6.86 \\
(2.03)\end{array}$ & $\begin{array}{c}-5.69 \\
(1.64)\end{array}$ & $\begin{array}{c}-6.08 \\
(1.79)\end{array}$ \\
\hline Q4 & $\begin{array}{c}-5.45 \\
(1.56)\end{array}$ & $\begin{array}{l}-2.41 \\
(0.90)\end{array}$ & $\begin{array}{c}-4.41 \\
(1.32)\end{array}$ & $\begin{array}{c}-5.45 \\
(1.56)\end{array}$ & $\begin{array}{c}-5.32 \\
(1.36)\end{array}$ & $\begin{array}{l}-4.61 \\
(1.34)\end{array}$ & Q4 & $\begin{array}{l}-5.65 \\
(1.65)\end{array}$ & $\begin{array}{l}-2.21 \\
(0.84)\end{array}$ & $\begin{array}{c}-4.31 \\
(1.30)\end{array}$ & $\begin{array}{c}-5.65 \\
(1.65)\end{array}$ & $\begin{array}{c}-5.35 \\
(1.38)\end{array}$ & $\begin{array}{l}-4.63 \\
(1.36)\end{array}$ \\
\hline Q5 & $\begin{array}{c}-1.22 \\
(0.27)\end{array}$ & $\begin{array}{l}-1.28 \\
(0.27)\end{array}$ & $\begin{array}{l}-3.62 \\
(0.78)\end{array}$ & $\begin{array}{l}-1.22 \\
(0.27)\end{array}$ & $\begin{array}{c}-5.93 \\
(1.55)\end{array}$ & $\begin{array}{l}-2.65 \\
(0.63)\end{array}$ & Q5 & $\begin{array}{c}-2.21 \\
(0.53)\end{array}$ & $\begin{array}{c}-2.31 \\
(0.49)\end{array}$ & $\begin{array}{l}-3.97 \\
(0.90)\end{array}$ & $\begin{array}{l}-2.21 \\
(0.53)\end{array}$ & $\begin{array}{l}-7.12 \\
(2.01)\end{array}$ & $\begin{array}{c}-3.57 \\
(0.89)\end{array}$ \\
\hline top-bottom & $\begin{array}{l}12.13 \\
(2.46)\end{array}$ & $\begin{array}{l}11.24 \\
(1.70)\end{array}$ & $\begin{array}{c}9.65 \\
(2.03)\end{array}$ & $\begin{array}{l}12.13 \\
(2.46)\end{array}$ & $\begin{array}{c}5.22 \\
(0.63)\end{array}$ & $\begin{array}{l}10.07 \\
(1.86)\end{array}$ & top-bottom & $\begin{array}{c}9.88 \\
(2.02)\end{array}$ & $\begin{array}{c}8.94 \\
(1.35)\end{array}$ & $\begin{array}{c}7.96 \\
(1.69)\end{array}$ & $\begin{array}{c}9.88 \\
(2.02)\end{array}$ & $\begin{array}{c}2.16 \\
(0.27)\end{array}$ & $\begin{array}{c}7.76 \\
(1.47)\end{array}$ \\
\hline
\end{tabular}


Table 11: Reverse Double Sorts Funds by $A C C$ and Past Performances. The table shows in Panel A the resulting $5 \times 5$ portfolios' alphas obtained by sorting funds in quintiles firstly by $A C C$ and then by past- $\hat{\alpha}$ performances. Panel $\mathrm{B}$ uses the core $A C C$ in which we drop those funds in the tails corresponding to both the top and bottom 5 per cent of the $A C C$ distribution in each $5 \times 5$ portfolio. The table reports the OLS estimates of each $5 \times 5$ portfolio's alpha (in percentage per year) and the corresponding absolute value of the t-statistics (in parentheses). Subscripts $3 f$ and $5 f$ stand for the three and five factors models used to compute alpha performances (Fama and French $(1993,2015)$ ). To compute past performance we use nine months of lookback period of daily observations on gross returns, which are determined by adding fund management fees to net returns. We then calculate the return of each quintile portfolio over the next three months using daily returns series and equally weighting funds in each $5 \times 5$ portfolio. $5 \times 5$ portfolios are redefined each quarter and the corresponding three months returns time series are connected across quarters to form a full sample period for each $5 \times 5$ portfolio. top-bottom is the portfolio obtained investing long in funds belonging to the best-performer quintile portfolio and short funds in the worst-performer quintile, within the same quintile determined in the first sort. Finally, the portfolio denoted as Avg invests equally in each of the five top-bottom portfolios. The sample period is June 2004 to June 2010.

Panel A: Sorting funds by $A C C$ and then by past- $\hat{\alpha}$

\begin{tabular}{|c|c|c|c|c|c|c|c|c|c|c|c|c|c|}
\hline $\begin{array}{l}A C C \rightarrow \\
\downarrow \hat{\alpha}_{3 f}\end{array}$ & ACC1 & ACC2 & ACC3 & $\mathrm{ACC} 4$ & ACC5 & Avg & $\begin{array}{l}A C C \rightarrow \\
\downarrow \hat{\alpha}_{5 f}\end{array}$ & ACC1 & $\mathrm{ACC} 2$ & ACC3 & $\mathrm{ACC} 4$ & ACC5 & Avg \\
\hline Q1 & $\begin{array}{l}-2.23 \\
(0.48)\end{array}$ & $\begin{array}{l}-4.05 \\
(1.28)\end{array}$ & $\begin{array}{l}-6.41 \\
(2.34)\end{array}$ & $\begin{array}{l}-4.33 \\
(1.75)\end{array}$ & $\begin{array}{l}-4.84 \\
(2.72)\end{array}$ & $\begin{array}{l}-4.37 \\
(1.71)\end{array}$ & Q1 & $\begin{array}{l}-1.21 \\
(0.26)\end{array}$ & $\begin{array}{l}-3.68 \\
(1.16)\end{array}$ & $\begin{array}{l}-6.26 \\
(2.32)\end{array}$ & $\begin{array}{l}-4.37 \\
(1.80)\end{array}$ & $\begin{array}{l}-4.66 \\
(2.63)\end{array}$ & $\begin{array}{l}-4.04 \\
(1.64)\end{array}$ \\
\hline Q2 & $\begin{array}{c}-0.06 \\
(0.02)\end{array}$ & $\begin{array}{l}-2.76 \\
(1.28)\end{array}$ & $\begin{array}{c}-1.99 \\
(0.89)\end{array}$ & $\begin{array}{l}-1.47 \\
(0.84)\end{array}$ & $\begin{array}{l}-3.92 \\
(2.07)\end{array}$ & $\begin{array}{c}-2.04 \\
(1.02)\end{array}$ & Q2 & $\begin{array}{c}0.34 \\
(0.10)\end{array}$ & $\begin{array}{c}-2.68 \\
(1.27)\end{array}$ & $\begin{array}{l}-1.79 \\
(0.82)\end{array}$ & $\begin{array}{l}-1.54 \\
(0.90)\end{array}$ & $\begin{array}{l}-3.97 \\
(2.09)\end{array}$ & $\begin{array}{l}-1.93 \\
(1.00)\end{array}$ \\
\hline Q3 & $\begin{array}{c}1.30 \\
(0.35)\end{array}$ & $\begin{array}{l}-0.40 \\
(0.27)\end{array}$ & $\begin{array}{c}0.93 \\
(0.54)\end{array}$ & $\begin{array}{l}-1.03 \\
(0.58)\end{array}$ & $\begin{array}{l}-3.66 \\
(1.91)\end{array}$ & $\begin{array}{c}-0.57 \\
(0.37)\end{array}$ & Q3 & $\begin{array}{c}1.96 \\
(0.54)\end{array}$ & $\begin{array}{l}-0.53 \\
(0.39)\end{array}$ & $\begin{array}{c}0.74 \\
(0.45)\end{array}$ & $\begin{array}{l}-1.11 \\
(0.63)\end{array}$ & $\begin{array}{c}-3.80 \\
(1.99)\end{array}$ & $\begin{array}{c}-0.55 \\
(0.40)\end{array}$ \\
\hline Q4 & $\begin{array}{c}4.27 \\
(1.29)\end{array}$ & $\begin{array}{c}0.18 \\
(0.13)\end{array}$ & $\begin{array}{c}0.62 \\
(0.35)\end{array}$ & $\begin{array}{l}-0.14 \\
(0.08)\end{array}$ & $\begin{array}{l}-2.56 \\
(1.33)\end{array}$ & $\begin{array}{c}0.47 \\
(0.07)\end{array}$ & Q4 & $\begin{array}{c}4.51 \\
(1.37)\end{array}$ & $\begin{array}{c}0.00 \\
(0.00)\end{array}$ & $\begin{array}{c}0.35 \\
(0.20)\end{array}$ & $\begin{array}{c}-0.02 \\
(0.01)\end{array}$ & $\begin{array}{c}-2.62 \\
(1.36)\end{array}$ & $\begin{array}{c}0.44 \\
(0.04)\end{array}$ \\
\hline Q5 & $\begin{array}{c}7.86 \\
(1.67)\end{array}$ & $\begin{array}{c}5.56 \\
(2.08)\end{array}$ & $\begin{array}{c}3.98 \\
(1.56)\end{array}$ & $\begin{array}{c}2.84 \\
(1.16)\end{array}$ & $\begin{array}{l}-1.34 \\
(0.65)\end{array}$ & $\begin{array}{c}3.78 \\
(1.16)\end{array}$ & Q5 & $\begin{array}{c}6.99 \\
(1.52)\end{array}$ & $\begin{array}{c}5.55 \\
(2.12)\end{array}$ & $\begin{array}{c}3.79 \\
(1.52)\end{array}$ & $\begin{array}{c}3.40 \\
(1.42)\end{array}$ & $\begin{array}{l}-1.05 \\
(0.51)\end{array}$ & $\begin{array}{c}3.74 \\
(1.22)\end{array}$ \\
\hline top-bottom & $\begin{array}{l}10.09 \\
(1.94)\end{array}$ & $\begin{array}{c}9.61 \\
(2.45)\end{array}$ & $\begin{array}{l}10.40 \\
(3.40)\end{array}$ & $\begin{array}{c}7.17 \\
(2.62)\end{array}$ & $\begin{array}{c}3.49 \\
(2.60)\end{array}$ & $\begin{array}{c}8.15 \\
(3.18)\end{array}$ & top-bottom & $\begin{array}{c}8.20 \\
(1.59)\end{array}$ & $\begin{array}{c}9.23 \\
(2.36)\end{array}$ & $\begin{array}{l}10.05 \\
(3.28)\end{array}$ & $\begin{array}{c}7.77 \\
(2.84)\end{array}$ & $\begin{array}{c}3.61 \\
(2.69)\end{array}$ & $\begin{array}{c}7.77 \\
(3.03)\end{array}$ \\
\hline
\end{tabular}

Panel B: Sorting funds by Core $A C C$ and then by past- $\hat{\alpha}$

$A C C \rightarrow \quad$ ACC1 1 ACC2 $\quad$ ACC3 ACC4 ACC5 Avg $\quad$ ACC $\rightarrow \quad$ ACC1 $\quad$ ACC2 $\quad$ ACC3 $\quad$ ACC4 ACC5 Avg

$\begin{array}{ll}\downarrow \hat{\alpha}_{3 f} & \downarrow \hat{\alpha}_{5 f}\end{array}$

\begin{tabular}{|c|c|c|c|c|c|c|c|c|c|c|c|c|c|}
\hline Q1 & $\begin{array}{l}-4.11 \\
(1.66)\end{array}$ & $\begin{array}{l}-4.50 \\
(1.44)\end{array}$ & $\begin{array}{l}-6.61 \\
(2.40)\end{array}$ & $\begin{array}{l}-4.11 \\
(1.66)\end{array}$ & $\begin{array}{l}-4.83 \\
(2.69)\end{array}$ & $\begin{array}{c}-4.83 \\
(1.97)\end{array}$ & Q1 & $\begin{array}{l}-4.25 \\
(1.75)\end{array}$ & $\begin{array}{l}-4.21 \\
(1.35)\end{array}$ & $\begin{array}{l}-6.42 \\
(2.37)\end{array}$ & $\begin{array}{l}-4.25 \\
(1.75)\end{array}$ & $\begin{array}{l}-4.67 \\
(2.61)\end{array}$ & $\begin{array}{l}-4.76 \\
(1.96)\end{array}$ \\
\hline Q2 & $\begin{array}{l}-1.37 \\
(0.79)\end{array}$ & $\begin{array}{l}-1.90 \\
(0.95)\end{array}$ & $\begin{array}{l}-1.65 \\
(0.77)\end{array}$ & $\begin{array}{l}-1.37 \\
(0.79)\end{array}$ & $\begin{array}{l}-3.87 \\
(2.04)\end{array}$ & $\begin{array}{c}-2.03 \\
(1.07)\end{array}$ & Q2 & $\begin{array}{l}-1.44 \\
(0.85)\end{array}$ & $\begin{array}{l}-1.93 \\
(0.99)\end{array}$ & $\begin{array}{l}-1.43 \\
(0.68)\end{array}$ & $\begin{array}{l}-1.44 \\
(0.85)\end{array}$ & $\begin{array}{l}-3.90 \\
(2.05)\end{array}$ & $\begin{array}{c}-2.03 \\
(1.08)\end{array}$ \\
\hline Q3 & $\begin{array}{c}-0.99 \\
(0.54)\end{array}$ & $\begin{array}{l}-0.20 \\
(0.14)\end{array}$ & $\begin{array}{c}1.19 \\
(0.70)\end{array}$ & $\begin{array}{l}-0.99 \\
(0.54)\end{array}$ & $\begin{array}{l}-3.58 \\
(1.88)\end{array}$ & $\begin{array}{c}-0.91 \\
(0.48)\end{array}$ & Q3 & $\begin{array}{l}-1.07 \\
(0.59)\end{array}$ & $\begin{array}{l}-0.41 \\
(0.31)\end{array}$ & $\begin{array}{c}0.92 \\
(0.56)\end{array}$ & $\begin{array}{l}-1.07 \\
(0.59)\end{array}$ & $\begin{array}{c}-3.72 \\
(1.95)\end{array}$ & $\begin{array}{c}-1.07 \\
(0.58)\end{array}$ \\
\hline Q4 & $\begin{array}{c}-0.33 \\
(0.18)\end{array}$ & $\begin{array}{c}0.05 \\
(0.04)\end{array}$ & $\begin{array}{c}0.99 \\
(0.55)\end{array}$ & $\begin{array}{l}-0.33 \\
(0.18)\end{array}$ & $\begin{array}{l}-2.29 \\
(1.21)\end{array}$ & $\begin{array}{c}-0.38 \\
(0.20)\end{array}$ & Q4 & $\begin{array}{c}-0.20 \\
(0.11)\end{array}$ & $\begin{array}{l}-0.10 \\
(0.08)\end{array}$ & $\begin{array}{c}0.75 \\
(0.43)\end{array}$ & $\begin{array}{l}-0.20 \\
(0.11)\end{array}$ & $\begin{array}{l}-2.40 \\
(1.27)\end{array}$ & $\begin{array}{c}-0.43 \\
(0.23)\end{array}$ \\
\hline Q5 & $\begin{array}{c}3.03 \\
(1.22)\end{array}$ & $\begin{array}{c}5.22 \\
(1.99)\end{array}$ & $\begin{array}{c}4.30 \\
(1.65)\end{array}$ & $\begin{array}{c}3.03 \\
(1.22)\end{array}$ & $\begin{array}{l}-1.20 \\
(0.58)\end{array}$ & $\begin{array}{c}2.88 \\
(1.10)\end{array}$ & Q5 & $\begin{array}{c}3.50 \\
(1.44)\end{array}$ & $\begin{array}{c}5.25 \\
(2.05)\end{array}$ & $\begin{array}{c}4.16 \\
(1.64)\end{array}$ & $\begin{array}{c}3.50 \\
(1.44)\end{array}$ & $\begin{array}{l}-0.92 \\
(0.45)\end{array}$ & $\begin{array}{c}3.10 \\
(1.22)\end{array}$ \\
\hline top-bottom & $\begin{array}{c}7.14 \\
(2.60)\end{array}$ & $\begin{array}{c}9.73 \\
(2.49)\end{array}$ & $\begin{array}{l}10.91 \\
(3.51)\end{array}$ & $\begin{array}{c}7.14 \\
(2.60)\end{array}$ & $\begin{array}{c}3.63 \\
(2.73)\end{array}$ & $\begin{array}{c}7.71 \\
(2.79)\end{array}$ & top-bottom & $\begin{array}{c}7.75 \\
(2.82)\end{array}$ & $\begin{array}{c}9.46 \\
(2.42)\end{array}$ & $\begin{array}{l}10.57 \\
(3.39)\end{array}$ & $\begin{array}{c}7.75 \\
(2.82)\end{array}$ & $\begin{array}{c}3.75 \\
(2.81)\end{array}$ & $\begin{array}{c}7.85 \\
(2.85)\end{array}$ \\
\hline
\end{tabular}




\section{Discussion}

For comparative purposes we also run the double sorts exercise using for the second sort

the $\hat{\delta}^{*}$ measure of managerial skill proposed by Cohen et al. (2005). In this specification we obtain prior to the crisis lower average differences than the ones determined by the $A C C$ index (see Table 12), with also more volatile top-bottom performances acr $A C C$ oss quintiles. For the interval 2007-2010 results of the five-factors model are almost in line with those for the $A C C$ sorting, while in the three-factors model sorting according to $\hat{\delta}^{*}$ produces better extra-performances than those for the $A C C$ index although for both criteria t-statistics do not support significant findings (cf. Table 7). The overall case for the whole period 2004-2010 is presented in Panel C of Table 12. On average this doublesort criterion determines lower extra-performances than those for the $A C C$ sort, with poor performances for low past- $\hat{\alpha}$ quintiles and less clear monotonic patterns as function of $\hat{\delta}^{*}$ levels.

Similarly to subsection 3.4, we also report in Table 13 the reverse sort quintiles based on $\hat{\delta}^{*}$, getting on average lower annualized extra-performances in each time window. The $\hat{\delta}^{*}$ indicator of Cohen et al. (2005) can thus be interpreted as an alternative measure of the skills of the manager, while the $A C C$ property can instead be used to refine the ability of the manager in a complementary way to past performances.

From an investor perspective it would be valuable to combine therefore the information present in both $A C C$ and past- $\hat{\alpha}$ to build portfolios. The highest performances in our cases are offered for instance by Q5ACC1-Q1ACC5 prior to the crisis (Panel A of Table 6) which would get annualized extra-performances equal to about $[17.94 ; 19.70]$ per cent. A similar strategy would be profitable also when the reference period is the entire interval from 2004 to 2010; interestingly, even circumscribing to the crisis period 2007-2010 only, following this investment style would have helped to mitigate those poor performances instead observed in most of the quintile portfolios. These alphas are, therefore, usually higher than those obtained using only a single quintile sort, suggesting that investors would benefit from combining both sources of information in constructing portfolios.

Similar practical results can be drawn for the reverse sorts of Tables 9-11. For instance, for the entire period 2004-2010 the strategy ACC1Q5-ACC5Q1 would generate annual 
performances of about $[12.70 ; 11.65]$ per cent, which represent again values higher than the average one-way quintile sort.

The $A C C$ index of a portfolio does not emerge simply as a proxy for managerial skills, but rather as a topological alternative to the diversification dimension of an investment strategy. For instance, investors can benefit from this topological information by combining the desired level of the $A C C$ index and selecting skilled managers according to past- $\hat{\alpha}$. Our analysis provides some guidelines for this decision: over a period affected by a boom and bust cycle, managers got better extra-performances by investing in less common assets, and those managers more skilled (namely, with higher past- $\hat{\alpha}$ ) seem to be the ones that mostly gained from extracting information from this topological feature. 
Table 12: Double Sorts Funds by Past Performances and $\hat{\delta}^{*}$. The table shows the resulting $5 \times 5$ portfolios' alphas obtained by sorting funds in quintiles firstly by past- $\hat{\alpha}$ performances and then by the $\hat{\delta}^{*}$ measure of managerial skills proposed by Cohen et al. (2005) for the second sort. The table reports the OLS estimates of each $5 \times 5$ portfolio's alpha (in percentage per year) and the corresponding absolute value of the t-statistics (in parentheses). Subscripts $3 f$ and $5 f$ stand for the three and five factors models used to compute alpha performances (Fama and French (1993, 2015)). To compute past performance we use nine months of lookback period of daily observations on gross returns, which are determined by adding fund management fees to net returns. We then calculate the return of each quintile portfolio over the next three months using daily returns series and equally weighting funds in each $5 \times 5$ portfolio. $5 \times 5$ portfolios are redefined each quarter and the corresponding three months returns time series are connected across quarters to form a full sample period for each $5 \times 5$ portfolio. top-bottom is the portfolio obtained investing long in funds belonging to the best-performer quintile portfolio and short funds in the worst-performer quintile, within the same quintile determined in the first sort. Finally, the portfolio denoted as $\mathrm{Avg}$ invests equally in each of the five top-bottom portfolios. Panel A stands for the interval from June 2004 to June 2007, Panel B refers to the period from September 2007 to June 2010, and Panel C from June 2004 to June 2010.

\begin{tabular}{|c|c|c|c|c|c|c|c|c|c|c|c|c|c|}
\hline \multirow[b]{2}{*}{$\begin{array}{l}\hat{\alpha}_{3 f} \rightarrow \\
\downarrow \hat{\delta}^{*}\end{array}$} & \multirow[b]{2}{*}{ Q1 } & \multicolumn{12}{|c|}{ Panel A (2004-2007): Sort funds by past- $\hat{\alpha}$ and then by $\hat{\delta}^{*}$ of Cohen et al. (2005) } \\
\hline & & Q2 & Q3 & Q4 & Q5 & Avg & $\begin{array}{l}\hat{\alpha}_{5 f} \rightarrow \\
\downarrow \hat{\delta}^{*}\end{array}$ & Q1 & Q2 & Q3 & Q4 & Q5 & Avg \\
\hline$\hat{\delta}^{*} 1$ & $\begin{array}{c}5.77 \\
(1.78)\end{array}$ & $\begin{array}{c}1.62 \\
(1.63)\end{array}$ & $\begin{array}{c}1.91 \\
(2.19)\end{array}$ & $\begin{array}{c}2.57 \\
(2.49)\end{array}$ & $\begin{array}{c}7.67 \\
(2.77)\end{array}$ & $\begin{array}{c}3.91 \\
(2.17)\end{array}$ & $\hat{\delta}^{*} 1$ & $\begin{array}{c}2.79 \\
(0.85)\end{array}$ & $\begin{array}{l}-0.26 \\
(0.25)\end{array}$ & $\begin{array}{l}-0.92 \\
(0.95)\end{array}$ & $\begin{array}{c}0.22 \\
(0.23)\end{array}$ & $\begin{array}{c}6.64 \\
(2.40)\end{array}$ & $\begin{array}{c}1.70 \\
(0.46)\end{array}$ \\
\hline$\hat{\delta}^{*} 2$ & $\begin{array}{l}3.90 \\
(2.05\end{array}$ & $\begin{array}{l}0.03 \\
(0.03\end{array}$ & $\begin{array}{c}1.39 \\
(1.56\end{array}$ & $\begin{array}{c}0.88 \\
(0.91\end{array}$ & $\begin{array}{c}8.73 \\
(3.07\end{array}$ & $\begin{array}{c}2.98 \\
(1.53\end{array}$ & $\hat{\delta}^{*} 2$ & $\begin{array}{c}1.52 \\
(0.97)\end{array}$ & $\begin{array}{c}0.78 \\
(0.85)\end{array}$ & $\begin{array}{c}0.35 \\
(0.39)\end{array}$ & $\begin{array}{c}2.36 \\
(2.33)\end{array}$ & $\begin{array}{c}8.39 \\
(2.65)\end{array}$ & $\begin{array}{c}2.68 \\
(1.44)\end{array}$ \\
\hline$\hat{\delta}^{*} 3$ & $\begin{array}{c}3.45 \\
(1.97)\end{array}$ & $\begin{array}{c}0.77 \\
(0.73)\end{array}$ & $\begin{array}{c}1.54 \\
(1.66)\end{array}$ & $\begin{array}{c}1.56 \\
(1.46)\end{array}$ & $\begin{array}{c}7.92 \\
(2.47)\end{array}$ & $\begin{array}{c}3.05 \\
(1.66)\end{array}$ & $\hat{\delta}^{*} 3$ & $\begin{array}{c}1.43 \\
(1.10)\end{array}$ & $\begin{array}{c}0.18 \\
(0.23)\end{array}$ & $\begin{array}{c}0.94 \\
(1.13)\end{array}$ & $\begin{array}{c}1.76 \\
(1.75)\end{array}$ & $\begin{array}{c}8.77 \\
(2.80)\end{array}$ & $\begin{array}{c}2.61 \\
(1.40)\end{array}$ \\
\hline$\hat{\delta}^{*} 4$ & $\begin{array}{c}2.92 \\
(1.79)\end{array}$ & $\begin{array}{c}0.97 \\
(0.94)\end{array}$ & $\begin{array}{c}1.89 \\
(1.86)\end{array}$ & $\begin{array}{c}2.04 \\
(2.02)\end{array}$ & $\begin{array}{l}10.14 \\
(2.89)\end{array}$ & $\begin{array}{c}3.59 \\
(1.90)\end{array}$ & $\hat{\delta}^{*} 4$ & $\begin{array}{c}0.29 \\
(0.23)\end{array}$ & $\begin{array}{c}1.15 \\
(1.32)\end{array}$ & $\begin{array}{c}1.30 \\
(1.77)\end{array}$ & $\begin{array}{c}0.80 \\
(0.82)\end{array}$ & $\begin{array}{l}11.26 \\
(3.15)\end{array}$ & $\begin{array}{c}2.96 \\
(1.46)\end{array}$ \\
\hline$\hat{\delta}^{*} 5$ & $\begin{array}{c}2.27 \\
(1.65)\end{array}$ & $\begin{array}{c}1.57 \\
(1.62)\end{array}$ & $\begin{array}{c}1.18 \\
(1.36)\end{array}$ & $\begin{array}{c}2.16 \\
(1.90)\end{array}$ & $\begin{array}{l}14.31 \\
(2.60)\end{array}$ & $\begin{array}{c}4.30 \\
(1.83)\end{array}$ & $\hat{\delta}^{*} 5$ & $\begin{array}{c}3.24 \\
(2.31)\end{array}$ & $\begin{array}{c}2.37 \\
(2.28)\end{array}$ & $\begin{array}{c}2.88 \\
(2.61)\end{array}$ & $\begin{array}{c}2.26 \\
(1.55)\end{array}$ & $\begin{array}{l}16.58 \\
(2.89)\end{array}$ & $\begin{array}{c}5.47 \\
(2.33)\end{array}$ \\
\hline top-bottom & $\begin{array}{l}-3.50 \\
(1.35)\end{array}$ & $\begin{array}{c}-0.04 \\
(0.07)\end{array}$ & $\begin{array}{c}-0.72 \\
(0.99)\end{array}$ & $\begin{array}{l}-0.41 \\
(0.57)\end{array}$ & $\begin{array}{c}6.63 \\
(1.83)\end{array}$ & $\begin{array}{c}0.38 \\
(0.44)\end{array}$ & top-bottom & $\begin{array}{c}0.45 \\
(0.17)\end{array}$ & $\begin{array}{c}2.63 \\
(2.27)\end{array}$ & $\begin{array}{c}3.80 \\
(3.04)\end{array}$ & $\begin{array}{c}2.04 \\
(1.53)\end{array}$ & $\begin{array}{c}9.94 \\
(2.43)\end{array}$ & $\begin{array}{c}3.77 \\
(1.33)\end{array}$ \\
\hline $\begin{array}{l}\hat{\alpha}_{3 f} \rightarrow \\
\downarrow \hat{\delta}^{*}\end{array}$ & Q1 & Q2 & $\begin{array}{l}\text { Pan } \\
\text { Q3 }\end{array}$ & $\begin{array}{c}\text { B (20 } \\
\text { Q4 }\end{array}$ & $\begin{array}{c}07-2010 \\
\text { Q5 }\end{array}$ & $\begin{array}{l}\text { Sort fu } \\
\text { Avg }\end{array}$ & $\begin{array}{l}\text { by past- } \hat{\alpha} \text { a } \\
\hat{\alpha}_{5 f} \rightarrow \\
\downarrow \hat{\delta}^{*}\end{array}$ & $\begin{array}{l}\text { d then } \\
\text { Q1 }\end{array}$ & $\begin{array}{l}\mathrm{y} \hat{\delta}^{*} \text { of } \\
\mathrm{Q} 2\end{array}$ & $\begin{array}{c}\text { Cohen e } \\
\text { Q3 }\end{array}$ & $\begin{array}{c}\text { al. (20 } \\
\text { Q4 }\end{array}$ & Q5) & Avg \\
\hline$\hat{\delta}^{*} 1$ & $\begin{array}{l}-15.57 \\
(1.80)\end{array}$ & $\begin{array}{c}-9.37 \\
(1.59)\end{array}$ & $\begin{array}{c}-7.94 \\
(1.90)\end{array}$ & $\begin{array}{l}-8.01 \\
(1.79)\end{array}$ & $\begin{array}{l}-13.11 \\
(2.02)\end{array}$ & $\begin{array}{l}-10.80 \\
(1.82)\end{array}$ & $\hat{\delta}^{*} 1$ & $\begin{array}{l}-13.71 \\
(1.55)\end{array}$ & $\begin{array}{l}-7.63 \\
(1.16)\end{array}$ & $\begin{array}{l}-7.27 \\
(1.70)\end{array}$ & $\begin{array}{l}-7.40 \\
(1.68)\end{array}$ & $\begin{array}{l}-4.45 \\
(1.12)\end{array}$ & $\begin{array}{l}-8.09 \\
(1.44)\end{array}$ \\
\hline$\hat{\delta}^{*} 2$ & $\begin{array}{r}-11.29 \\
(1.43)\end{array}$ & $\begin{array}{c}-6.47 \\
(1.56)\end{array}$ & $\begin{array}{c}-5.92 \\
(1.69)\end{array}$ & $\begin{array}{l}-6.38 \\
(1.45)\end{array}$ & $\begin{array}{c}-5.03 \\
(1.07)\end{array}$ & $\begin{array}{l}-7.02 \\
(1.44)\end{array}$ & $\hat{\delta}^{*} 2$ & $\begin{array}{c}-9.33 \\
(1.23)\end{array}$ & $\begin{array}{c}-5.42 \\
(1.22)\end{array}$ & $\begin{array}{c}-4.21 \\
(1.19)\end{array}$ & $\begin{array}{c}-5.31 \\
(1.29)\end{array}$ & $\begin{array}{c}-3.36 \\
(0.93)\end{array}$ & $\begin{array}{c}-5.53 \\
(1.17)\end{array}$ \\
\hline$\hat{\delta}^{*} 3$ & $\begin{array}{l}-8.54 \\
(1.19)\end{array}$ & $\begin{array}{l}-8.26 \\
(2.00)\end{array}$ & $\begin{array}{l}-7.33 \\
(2.04)\end{array}$ & $\begin{array}{l}-4.70 \\
(1.20)\end{array}$ & $\begin{array}{c}-3.71 \\
(0.82)\end{array}$ & $\begin{array}{l}-6.51 \\
(1.45)\end{array}$ & $\hat{\delta}^{*} 3$ & $\begin{array}{l}-9.06 \\
(1.33)\end{array}$ & $\begin{array}{l}-8.28 \\
(2.12)\end{array}$ & $\begin{array}{l}-6.27 \\
(1.84)\end{array}$ & $\begin{array}{l}-4.81 \\
(1.25)\end{array}$ & $\begin{array}{l}-2.45 \\
(0.61)\end{array}$ & $\begin{array}{l}-6.18 \\
(1.43)\end{array}$ \\
\hline$\hat{\delta}^{*} 4$ & $\begin{array}{l}-6.04 \\
(1.02\end{array}$ & $\begin{array}{l}-6.26 \\
(1.65\end{array}$ & $\begin{array}{l}-3.71 \\
(1.19\end{array}$ & $\begin{array}{l}-3.26 \\
(0.96\end{array}$ & $\begin{array}{r}-3.15 \\
(0.59\end{array}$ & $\begin{array}{l}-4.48 \\
(1.08\end{array}$ & $\hat{\delta}^{*} 4$ & $\begin{array}{l}-7.48 \\
(1.30)\end{array}$ & $\begin{array}{l}-8.21 \\
(2.11)\end{array}$ & $\begin{array}{l}-4.25 \\
(1.07)\end{array}$ & $\begin{array}{l}-3.62 \\
(1.11)\end{array}$ & $\begin{array}{l}-4.44 \\
(0.95)\end{array}$ & $\begin{array}{l}-5.60 \\
(1.31)\end{array}$ \\
\hline$\hat{\delta}^{*} 5$ & $\begin{array}{c}-10.74 \\
(2.20)\end{array}$ & $\begin{array}{c}-4.74 \\
(1.21)\end{array}$ & $\begin{array}{c}-5.84 \\
(1.74)\end{array}$ & $\begin{array}{l}-4.80 \\
(1.29)\end{array}$ & $\begin{array}{c}-2.24 \\
(0.31)\end{array}$ & $\begin{array}{c}-5.67 \\
(1.35)\end{array}$ & $\hat{\delta}^{*} 5$ & $\begin{array}{c}-11.72 \\
(2.84)\end{array}$ & $\begin{array}{l}-4.80 \\
(1.33)\end{array}$ & $\begin{array}{c}-5.78 \\
(1.73)\end{array}$ & $\begin{array}{c}-3.89 \\
(1.14)\end{array}$ & $\begin{array}{l}-3.57 \\
(0.51)\end{array}$ & $\begin{array}{c}-5.95 \\
(1.51)\end{array}$ \\
\hline top-bottom & $\begin{array}{c}4.83 \\
(0.66)\end{array}$ & $\begin{array}{c}4.62 \\
(0.93)\end{array}$ & $\begin{array}{c}2.11 \\
(0.61)\end{array}$ & $\begin{array}{c}3.21 \\
(0.87)\end{array}$ & $\begin{array}{l}10.88 \\
(1.52)\end{array}$ & $\begin{array}{c}5.13 \\
(1.26)\end{array}$ & top-bottom & $\begin{array}{c}1.98 \\
(0.28)\end{array}$ & $\begin{array}{c}2.82 \\
(0.51)\end{array}$ & $\begin{array}{c}1.50 \\
(0.42)\end{array}$ & $\begin{array}{c}3.51 \\
(0.89)\end{array}$ & $\begin{array}{c}0.88 \\
(0.15)\end{array}$ & $\begin{array}{c}2.14 \\
(0.55)\end{array}$ \\
\hline $\begin{array}{l}\hat{\alpha}_{3 f} \rightarrow \\
\downarrow \hat{\delta}^{*}\end{array}$ & Q1 & Q2 & $\begin{array}{l}\text { Pan } \\
\text { Q3 }\end{array}$ & $\begin{array}{c}\mathrm{C}(2 \\
\mathrm{Q} 4\end{array}$ & $\begin{array}{c}4-2010 \\
\text { Q5 }\end{array}$ & $\begin{array}{l}\text { Sort } f \\
\text { Avg }\end{array}$ & $\begin{array}{l}\text { by past- } \hat{\alpha} \\
\hat{\alpha}_{5 f} \rightarrow \\
\downarrow \hat{\delta}^{*} \\
\end{array}$ & $\begin{array}{l}\text { then } \\
\text { Q1 }\end{array}$ & $\begin{array}{l}\mathrm{y} \hat{\delta}^{*} \text { of } \\
\mathrm{Q} 2\end{array}$ & $\begin{array}{c}\text { Cohen } \\
\text { Q3 }\end{array}$ & $\begin{array}{l}\text { al. }(20 \\
\text { Q4 }\end{array}$ & 5) & Avg \\
\hline$\hat{\delta}^{*} 1$ & $\begin{array}{l}-3.87 \\
(0.89)\end{array}$ & $\begin{array}{c}-2.34 \\
(0.82)\end{array}$ & $\begin{array}{l}-1.88 \\
(0.91)\end{array}$ & $\begin{array}{l}-2.25 \\
(1.04)\end{array}$ & $\begin{array}{l}-3.47 \\
(1.07)\end{array}$ & $\begin{array}{l}-2.76 \\
(0.95)\end{array}$ & $\hat{\delta}^{*} 1$ & $\begin{array}{l}-3.32 \\
(0.74)\end{array}$ & $\begin{array}{l}-1.88 \\
(0.60)\end{array}$ & $\begin{array}{c}-0.98 \\
(0.46)\end{array}$ & $\begin{array}{l}-1.99 \\
(0.94)\end{array}$ & $\begin{array}{c}0.24 \\
(0.11)\end{array}$ & $\begin{array}{l}-1.58 \\
(0.53)\end{array}$ \\
\hline$\hat{\delta}^{*} 2$ & $\begin{array}{c}-3.14 \\
(0.82)\end{array}$ & $\begin{array}{c}-2.38 \\
(1.17)\end{array}$ & $\begin{array}{l}-1.41 \\
(0.83)\end{array}$ & $\begin{array}{l}-1.28 \\
(0.61)\end{array}$ & $\begin{array}{c}0.79 \\
(0.32)\end{array}$ & $\begin{array}{l}-1.48 \\
(0.62)\end{array}$ & $\hat{\delta}^{*} 2$ & $\begin{array}{l}-2.89 \\
(0.79)\end{array}$ & $\begin{array}{l}-1.72 \\
(0.80)\end{array}$ & $\begin{array}{c}-0.82 \\
(0.47)\end{array}$ & $\begin{array}{l}-0.91 \\
(0.47)\end{array}$ & $\begin{array}{c}1.98 \\
(0.93)\end{array}$ & $\begin{array}{c}-0.87 \\
(0.32)\end{array}$ \\
\hline$\hat{\delta}^{*} 3$ & $\begin{array}{l}-2.91 \\
(0.83)\end{array}$ & $\begin{array}{c}-3.17 \\
(1.61)\end{array}$ & $\begin{array}{c}-2.88 \\
(1.68)\end{array}$ & $\begin{array}{l}-1.23 \\
(0.66)\end{array}$ & $\begin{array}{c}2.59 \\
(0.97)\end{array}$ & $\begin{array}{l}-1.52 \\
(0.76)\end{array}$ & $\hat{\delta}^{*} 3$ & $\begin{array}{c}-3.62 \\
(1.11)\end{array}$ & $\begin{array}{l}-3.56 \\
(1.91)\end{array}$ & $\begin{array}{l}-1.81 \\
(1.11)\end{array}$ & $\begin{array}{l}-1.46 \\
(0.79)\end{array}$ & $\begin{array}{c}3.26 \\
(1.32)\end{array}$ & $\begin{array}{c}-1.44 \\
(0.72)\end{array}$ \\
\hline$\hat{\delta}^{*} 4$ & $\begin{array}{l}-2.36 \\
(0.83)\end{array}$ & $\begin{array}{c}-2.61 \\
(1.42)\end{array}$ & $\begin{array}{c}-0.58 \\
(0.39)\end{array}$ & $\begin{array}{c}0.06 \\
(0.04)\end{array}$ & $\begin{array}{c}3.62 \\
(1.16)\end{array}$ & $\begin{array}{l}-0.37 \\
(0.29)\end{array}$ & $\hat{\delta}^{*} 4$ & $\begin{array}{l}-3.04 \\
(1.12)\end{array}$ & $\begin{array}{l}-3.78 \\
(2.05)\end{array}$ & $\begin{array}{l}-1.31 \\
(0.70)\end{array}$ & $\begin{array}{l}-0.36 \\
(0.22)\end{array}$ & $\begin{array}{c}3.75 \\
(1.28)\end{array}$ & $\begin{array}{c}-0.95 \\
(0.56)\end{array}$ \\
\hline$\hat{\delta}^{*} 5$ & $\begin{array}{l}-4.11 \\
(1.61)\end{array}$ & $\begin{array}{c}-0.23 \\
(0.12)\end{array}$ & $\begin{array}{c}0.08 \\
(0.04)\end{array}$ & $\begin{array}{c}1.30 \\
(0.63)\end{array}$ & $\begin{array}{c}7.48 \\
(1.61)\end{array}$ & $\begin{array}{c}0.90 \\
(0.11)\end{array}$ & $\hat{\delta}^{*} 5$ & $\begin{array}{l}-5.80 \\
(2.90)\end{array}$ & $\begin{array}{l}-1.12 \\
(0.62)\end{array}$ & $\begin{array}{c}-0.66 \\
(0.38)\end{array}$ & $\begin{array}{c}1.16 \\
(0.61)\end{array}$ & $\begin{array}{c}7.50 \\
(1.65)\end{array}$ & $\begin{array}{c}0.22 \\
(0.33)\end{array}$ \\
\hline top-bottom & $\begin{array}{c}-0.24 \\
(0.06)\end{array}$ & $\begin{array}{c}2.10 \\
(0.85)\end{array}$ & $\begin{array}{c}1.95 \\
(1.03)\end{array}$ & $\begin{array}{c}3.55 \\
(1.65)\end{array}$ & $\begin{array}{l}10.95 \\
(2.58)\end{array}$ & $\begin{array}{c}3.66 \\
(1.69)\end{array}$ & top-bottom & $\begin{array}{l}-2.48 \\
(0.66)\end{array}$ & $\begin{array}{c}0.77 \\
(0.28)\end{array}$ & $\begin{array}{c}0.32 \\
(0.16)\end{array}$ & $\begin{array}{c}3.15 \\
(1.42)\end{array}$ & $\begin{array}{c}7.26 \\
(1.91)\end{array}$ & $\begin{array}{c}1.80 \\
(0.86)\end{array}$ \\
\hline
\end{tabular}


Table 13: Reverse Double Sorts Funds by $\hat{\delta}^{*}$ and Past Performances. The table shows the resulting $5 \times 5$ portfolios' alphas obtained by sorting funds in quintiles firstly by $\hat{\delta}^{*}$ and then by past- $\hat{\alpha}$ performances. The table reports the OLS estimates of each $5 \times 5$ portfolio's alpha (in percentage per year) and the corresponding absolute value of the t-statistics (in parentheses). Subscripts $3 f$ and $5 f$ stand for the three and five factors models used to compute alpha performances (Fama and French $(1993,2015))$. To compute past performance we use nine months of lookback period of daily observations on gross returns, which are determined by adding fund management fees to net returns. We then calculate the return of each quintile portfolio over the next three months using daily returns series and equally weighting funds in each $5 \times 5$ portfolio. $5 \times 5$ portfolios are redefined each quarter and the corresponding three months returns time series are connected across quarters to form a full sample period for each $5 \times 5$ portfolio. top-bottom is the portfolio obtained investing long in funds belonging to the best-performer quintile portfolio and short funds in the worst-performer quintile, within the same quintile determined in the first sort. Finally, the portfolio denoted as Avg invests equally in each of the five top-bottom portfolios. Panel A stands for the interval from June 2004 to June 2007, Panel B refers to the period from September 2007 to June 2010, and Panel C from June 2004 to June 2010.

\begin{tabular}{|c|c|c|c|c|c|c|c|c|c|c|c|c|c|}
\hline \multirow[b]{2}{*}{$\begin{array}{l}\hat{\delta}^{*} \rightarrow \\
\downarrow \hat{\alpha}_{3 f}\end{array}$} & \multirow[b]{2}{*}{$\hat{\delta}^{*} 1$} & \multirow[b]{2}{*}{$\hat{\delta}^{*} 2$} & \multicolumn{3}{|c|}{ 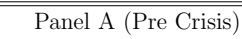 } & \multicolumn{7}{|c|}{ "Sorting funds by $\hat{\delta}^{*}$ of Cohen et al. (2005) and then by past- $\hat{\alpha}$} & \multirow[b]{2}{*}{ Avg } \\
\hline & & & $\hat{\delta}^{*} 3$ & $\hat{\delta}^{*} 4$ & $\hat{\delta}^{*} 5$ & Avg & $\begin{array}{l}\hat{\delta}^{*} \rightarrow \\
\downarrow \hat{\alpha}_{5 f}\end{array}$ & $\hat{\delta}^{*} 1$ & $\hat{\delta}^{*} 2$ & $\hat{\delta}^{*} 3$ & $\hat{\delta}^{*} 4$ & $\hat{\delta}^{*} 5$ & \\
\hline Q1 & $\begin{array}{c}8.63 \\
(1.85)\end{array}$ & $\begin{array}{c}1.58 \\
(1.04)\end{array}$ & $\begin{array}{c}1.56 \\
(1.38)\end{array}$ & $\begin{array}{c}2.79 \\
(2.88)\end{array}$ & $\begin{array}{c}10.67 \\
(2.91)\end{array}$ & $\begin{array}{c}5.04 \\
(2.01)\end{array}$ & Q1 & $\begin{array}{c}4.08 \\
(0.89)\end{array}$ & $\begin{array}{c}0.57 \\
(0.34)\end{array}$ & $\begin{array}{l}-0.90 \\
(0.69)\end{array}$ & $\begin{array}{l}-0.26 \\
(0.26)\end{array}$ & $\begin{array}{c}9.02 \\
(2.39)\end{array}$ & $\begin{array}{c}2.50 \\
(0.53)\end{array}$ \\
\hline Q2 & $\begin{array}{c}2.73 \\
(1.03)\end{array}$ & $\begin{array}{c}1.01 \\
(0.65)\end{array}$ & $\begin{array}{c}0.77 \\
(0.72)\end{array}$ & $\begin{array}{l}-0.93 \\
(0.90)\end{array}$ & $\begin{array}{l}10.18 \\
(2.73)\end{array}$ & $\begin{array}{c}2.75 \\
(0.84)\end{array}$ & Q2 & $\begin{array}{c}0.34 \\
(0.14)\end{array}$ & $\begin{array}{c}0.60 \\
(0.51)\end{array}$ & $\begin{array}{c}1.36 \\
(1.39)\end{array}$ & $\begin{array}{c}0.25 \\
(0.24)\end{array}$ & $\begin{array}{l}11.81 \\
(3.03)\end{array}$ & $\begin{array}{c}2.87 \\
(1.06)\end{array}$ \\
\hline Q3 & $\begin{array}{c}5.80 \\
(2.96)\end{array}$ & $\begin{array}{c}2.74 \\
(1.86)\end{array}$ & $\begin{array}{c}1.25 \\
(0.96)\end{array}$ & $\begin{array}{c}1.61 \\
(1.74)\end{array}$ & $\begin{array}{c}12.17 \\
(2.98)\end{array}$ & $\begin{array}{c}4.71 \\
(2.10)\end{array}$ & Q3 & $\begin{array}{c}1.99 \\
(1.20)\end{array}$ & $\begin{array}{l}-1.24 \\
(1.03)\end{array}$ & $\begin{array}{l}-0.35 \\
(0.37)\end{array}$ & $\begin{array}{c}0.42 \\
(0.52)\end{array}$ & $\begin{array}{l}12.84 \\
(3.04)\end{array}$ & $\begin{array}{c}2.73 \\
(0.67))\end{array}$ \\
\hline Q4 & $\begin{array}{c}3.51 \\
(1.81)\end{array}$ & $\begin{array}{c}2.19 \\
(1.35)\end{array}$ & $\begin{array}{c}1.33 \\
(1.13)\end{array}$ & $\begin{array}{c}0.80 \\
(0.88)\end{array}$ & $\begin{array}{c}11.24 \\
(2.57)\end{array}$ & $\begin{array}{c}3.81 \\
(1.55)\end{array}$ & Q4 & $\begin{array}{c}1.79 \\
(1.08)\end{array}$ & $\begin{array}{c}1.39 \\
(1.14)\end{array}$ & $\begin{array}{c}1.49 \\
(1.61)\end{array}$ & $\begin{array}{c}1.39 \\
(1.43)\end{array}$ & $\begin{array}{l}11.42 \\
(2.48)\end{array}$ & $\begin{array}{c}3.50 \\
(1.55)\end{array}$ \\
\hline Q5 & $\begin{array}{c}2.81 \\
(1.56)\end{array}$ & $\begin{array}{c}2.09 \\
(1.40)\end{array}$ & $\begin{array}{c}1.70 \\
(1.44)\end{array}$ & $\begin{array}{c}1.20 \\
(1.26)\end{array}$ & $\begin{array}{l}16.29 \\
(2.55)\end{array}$ & $\begin{array}{c}4.82 \\
(1.64)\end{array}$ & Q5 & $\begin{array}{c}4.41 \\
(2.56)\end{array}$ & $\begin{array}{c}2.51 \\
(1.56)\end{array}$ & $\begin{array}{c}2.41 \\
(1.92)\end{array}$ & $\begin{array}{c}2.64 \\
(2.05)\end{array}$ & $\begin{array}{l}19.16 \\
(2.89)\end{array}$ & $\begin{array}{c}6.23 \\
(2.20)\end{array}$ \\
\hline top-bottom & $\begin{array}{c}-5.82 \\
(1.46)\end{array}$ & $\begin{array}{c}0.51 \\
(0.43)\end{array}$ & $\begin{array}{c}0.14 \\
(0.15)\end{array}$ & $\begin{array}{l}-1.59 \\
(1.67)\end{array}$ & $\begin{array}{c}5.63 \\
(1.38)\end{array}$ & $\begin{array}{c}-0.23 \\
(0.18)\end{array}$ & top-bottom & $\begin{array}{c}0.34 \\
(0.08)\end{array}$ & $\begin{array}{c}1.93 \\
(1.03)\end{array}$ & $\begin{array}{c}3.32 \\
(2.15)\end{array}$ & $\begin{array}{c}2.90 \\
(2.05)\end{array}$ & $\begin{array}{c}10.14 \\
(2.15)\end{array}$ & $\begin{array}{c}3.72 \\
(2.58)\end{array}$ \\
\hline
\end{tabular}

Panel B (Crisis): Sorting funds by $\hat{\delta}^{*}$ of Cohen et al. (2005) and then by past- $\hat{\alpha}$

\begin{tabular}{|c|c|c|c|c|c|c|c|c|c|c|c|c|c|}
\hline $\begin{array}{l}\hat{\delta}^{*} \rightarrow \\
\downarrow \hat{\alpha}_{3 f}\end{array}$ & $\hat{\delta}^{*} 1$ & $\hat{\delta}^{*} 2$ & $\hat{\delta}^{*} 3$ & $\hat{\delta}^{*} 4$ & $\hat{\delta}^{*} 5$ & Avg & $\begin{array}{l}\hat{\delta}^{*} \rightarrow \\
\downarrow \hat{\alpha}_{5 f}\end{array}$ & $\hat{\delta}^{*} 1$ & $\hat{\delta}^{*} 2$ & $\hat{\delta}^{*} 3$ & $\hat{\delta}^{*} 4$ & $\hat{\delta}^{*} 5$ & Avg \\
\hline Q1 & $\begin{array}{r}-13.17 \\
(1.56)\end{array}$ & $\begin{array}{l}-7.28 \\
(1.86)\end{array}$ & $\begin{array}{l}-4.85 \\
(1.43)\end{array}$ & $\begin{array}{l}-7.08 \\
(1.82)\end{array}$ & $\begin{array}{l}-5.59 \\
(1.19)\end{array}$ & $\begin{array}{l}-7.59 \\
(1.57)\end{array}$ & Q1 & $\begin{array}{l}-20.71 \\
(2.29)\end{array}$ & $\begin{array}{l}-9.09 \\
(1.81)\end{array}$ & $\begin{array}{l}-10.29 \\
(2.56)\end{array}$ & $\begin{array}{l}-7.36 \\
(1.89)\end{array}$ & $\begin{array}{l}-7.27 \\
(1.53)\end{array}$ & $\begin{array}{c}-10.94 \\
(2.02)\end{array}$ \\
\hline Q2 & $\begin{array}{c}-9.79 \\
(1.33)\end{array}$ & $\begin{array}{c}-6.88 \\
(1.78)\end{array}$ & $\begin{array}{c}-6.99 \\
(1.77)\end{array}$ & $\begin{array}{l}-2.97 \\
(0.90)\end{array}$ & $\begin{array}{c}-5.28 \\
(1.13)\end{array}$ & $\begin{array}{c}-6.38 \\
(1.38)\end{array}$ & Q2 & $\begin{array}{c}-8.11 \\
(1.22)\end{array}$ & $\begin{array}{l}-7.58 \\
(1.83)\end{array}$ & $\begin{array}{l}-7.55 \\
(1.99)\end{array}$ & $\begin{array}{l}-2.90 \\
(0.84)\end{array}$ & $\begin{array}{l}-1.78 \\
(0.43)\end{array}$ & $\begin{array}{c}-5.58 \\
(1.26)\end{array}$ \\
\hline Q3 & $\begin{array}{l}-9.07 \\
(1.37)\end{array}$ & $\begin{array}{c}-6.20 \\
(1.74)\end{array}$ & $\begin{array}{l}-3.43 \\
(0.96)\end{array}$ & $\begin{array}{c}-5.80 \\
(1.61)\end{array}$ & $\begin{array}{c}-4.72 \\
(0.99)\end{array}$ & $\begin{array}{c}-5.84 \\
(1.33)\end{array}$ & Q3 & $\begin{array}{l}-6.50 \\
(0.97)\end{array}$ & $\begin{array}{c}-6.56 \\
(1.90)\end{array}$ & $\begin{array}{l}-5.24 \\
(1.42)\end{array}$ & $\begin{array}{l}-3.46 \\
(1.01)\end{array}$ & $\begin{array}{l}-3.44 \\
(0.96)\end{array}$ & $\begin{array}{c}-5.04 \\
(1.25)\end{array}$ \\
\hline Q4 & $\begin{array}{c}-8.01 \\
(1.40)\end{array}$ & $\begin{array}{c}-4.62 \\
(1.23)\end{array}$ & $\begin{array}{c}-6.40 \\
(1.80)\end{array}$ & $\begin{array}{l}-4.24 \\
(1.19)\end{array}$ & $\begin{array}{c}-4.86 \\
(0.86)\end{array}$ & $\begin{array}{c}-5.62 \\
(1.30)\end{array}$ & Q4 & $\begin{array}{c}-8.31 \\
(1.26)\end{array}$ & $\begin{array}{c}-4.82 \\
(1.37)\end{array}$ & $\begin{array}{l}-5.30 \\
(1.27)\end{array}$ & $\begin{array}{c}-3.79 \\
(1.05)\end{array}$ & $\begin{array}{l}-1.50 \\
(0.34)\end{array}$ & $\begin{array}{c}-4.74 \\
(1.06)\end{array}$ \\
\hline Q5 & $\begin{array}{c}-11.05 \\
(1.84)\end{array}$ & $\begin{array}{l}-5.67 \\
(1.51)\end{array}$ & $\begin{array}{l}-5.98 \\
(1.54)\end{array}$ & $\begin{array}{c}-5.97 \\
(1.68)\end{array}$ & $\begin{array}{l}-3.79 \\
(0.50)\end{array}$ & $\begin{array}{c}-6.49 \\
(1.41)\end{array}$ & Q5 & $\begin{array}{c}-6.27 \\
(1.16)\end{array}$ & $\begin{array}{c}-6.29 \\
(1.48)\end{array}$ & $\begin{array}{c}-5.91 \\
(1.60)\end{array}$ & $\begin{array}{c}-3.94 \\
(1.09)\end{array}$ & $\begin{array}{c}-4.29 \\
(0.61)\end{array}$ & $\begin{array}{c}-5.34 \\
(1.19)\end{array}$ \\
\hline top-bottom & $\begin{array}{c}2.12 \\
(0.39)\end{array}$ & $\begin{array}{c}1.61 \\
(1.35)\end{array}$ & $\begin{array}{l}-1.13 \\
(1.02)\end{array}$ & $\begin{array}{c}1.11 \\
(0.90)\end{array}$ & $\begin{array}{c}1.80 \\
(0.44)\end{array}$ & $\begin{array}{c}1.10 \\
(0.74)\end{array}$ & top-bottom & $\begin{array}{l}14.43 \\
(2.41)\end{array}$ & $\begin{array}{c}2.81 \\
(0.96)\end{array}$ & $\begin{array}{c}4.38 \\
(2.06)\end{array}$ & $\begin{array}{c}3.42 \\
(1.34)\end{array}$ & $\begin{array}{c}2.98 \\
(0.57)\end{array}$ & $\begin{array}{c}5.60 \\
(2.26)\end{array}$ \\
\hline
\end{tabular}

\begin{tabular}{|c|c|c|c|c|c|c|c|c|c|c|c|c|c|}
\hline \multirow[b]{2}{*}{$\begin{array}{l}\hat{\delta}^{*} \rightarrow \\
\downarrow \hat{\alpha}_{3 f}\end{array}$} & \multirow[b]{2}{*}{$\hat{\delta}^{*} 1$} & \multicolumn{12}{|c|}{ Panel B: Sorting funds by $\hat{\delta}^{*}$ of Cohen et al. (2005) and then by past- $\hat{\alpha}$} \\
\hline & & $\hat{\delta}^{*} 2$ & $\hat{\delta}^{*} 3$ & $\hat{\delta}^{*} 4$ & $\hat{\delta}^{*} 5$ & $\operatorname{Avg}$ & $\begin{array}{l}\hat{\delta}^{*} \rightarrow \\
\downarrow \hat{\alpha}_{5 f}\end{array}$ & $\hat{\delta}^{*} 1$ & $\hat{\delta}^{*} 2$ & $\hat{\delta}^{*} 3$ & $\hat{\delta}^{*} 4$ & $\hat{\delta}^{*} 5$ & Avg \\
\hline Q1 & $\begin{array}{c}-2.46 \\
(0.57)\end{array}$ & $\begin{array}{l}-2.60 \\
(1.37)\end{array}$ & $\begin{array}{l}-1.02 \\
(0.62)\end{array}$ & $\begin{array}{c}-1.68 \\
(0.89)\end{array}$ & $\begin{array}{c}1.93 \\
(0.72)\end{array}$ & $\begin{array}{l}-1.17 \\
(0.55)\end{array}$ & Q1 & $\begin{array}{c}-7.51 \\
(1.66)\end{array}$ & $\begin{array}{l}-4.38 \\
(1.84)\end{array}$ & $\begin{array}{c}-5.06 \\
(2.64)\end{array}$ & $\begin{array}{l}-2.96 \\
(1.57)\end{array}$ & $\begin{array}{c}0.00 \\
(0.00)\end{array}$ & $\begin{array}{c}-3.98 \\
(1.54)\end{array}$ \\
\hline Q2 & $\begin{array}{l}-2.05 \\
(0.57)\end{array}$ & $\begin{array}{c}-3.13 \\
(1.67)\end{array}$ & $\begin{array}{c}-2.22 \\
(1.16)\end{array}$ & $\begin{array}{c}-0.60 \\
(0.38)\end{array}$ & $\begin{array}{c}2.49 \\
(0.93)\end{array}$ & $\begin{array}{l}-1.10 \\
(0.57)\end{array}$ & Q2 & $\begin{array}{l}-2.31 \\
(0.72)\end{array}$ & $\begin{array}{l}-3.05 \\
(1.55)\end{array}$ & $\begin{array}{c}-3.05 \\
(1.68)\end{array}$ & $\begin{array}{c}0.16 \\
(0.09)\end{array}$ & $\begin{array}{c}3.83 \\
(1.46)\end{array}$ & $\begin{array}{c}-0.89 \\
(0.48)\end{array}$ \\
\hline Q3 & $\begin{array}{l}-1.71 \\
(0.53)\end{array}$ & $\begin{array}{l}-2.38 \\
(1.35)\end{array}$ & $\begin{array}{c}-0.56 \\
(0.32)\end{array}$ & $\begin{array}{c}-1.38 \\
(0.78)\end{array}$ & $\begin{array}{c}2.23 \\
(0.79)\end{array}$ & $\begin{array}{c}-0.76 \\
(0.44)\end{array}$ & Q3 & $\begin{array}{l}-1.57 \\
(0.49)\end{array}$ & $\begin{array}{c}-2.78 \\
(1.67)\end{array}$ & $\begin{array}{l}-1.53 \\
(0.87)\end{array}$ & $\begin{array}{l}-0.31 \\
(0.19)\end{array}$ & $\begin{array}{c}3.14 \\
(1.29)\end{array}$ & $\begin{array}{c}-0.61 \\
(0.38)\end{array}$ \\
\hline Q4 & $\begin{array}{c}-1.81 \\
(0.64)\end{array}$ & $\begin{array}{l}-1.57 \\
(0.85)\end{array}$ & $\begin{array}{c}-1.62 \\
(0.93)\end{array}$ & $\begin{array}{c}-0.50 \\
(0.29)\end{array}$ & $\begin{array}{c}3.20 \\
(0.98)\end{array}$ & $\begin{array}{c}-0.46 \\
(0.35)\end{array}$ & Q4 & $\begin{array}{c}-3.22 \\
(1.03)\end{array}$ & $\begin{array}{c}-1.40 \\
(0.82)\end{array}$ & $\begin{array}{l}-1.45 \\
(0.74)\end{array}$ & $\begin{array}{c}-0.92 \\
(0.53)\end{array}$ & $\begin{array}{c}5.02 \\
(1.75)\end{array}$ & $\begin{array}{c}-0.39 \\
(0.27)\end{array}$ \\
\hline Q5 & $\begin{array}{c}-3.62 \\
(1.26)\end{array}$ & $\begin{array}{l}-1.88 \\
(1.03)\end{array}$ & $\begin{array}{c}-1.93 \\
(1.03)\end{array}$ & $\begin{array}{c}-1.28 \\
(0.73)\end{array}$ & $\begin{array}{c}5.84 \\
(1.27)\end{array}$ & $\begin{array}{c}-0.57 \\
(0.56)\end{array}$ & Q5 & $\begin{array}{c}-0.37 \\
(0.14)\end{array}$ & $\begin{array}{l}-1.21 \\
(0.59)\end{array}$ & $\begin{array}{c}-0.64 \\
(0.35)\end{array}$ & $\begin{array}{l}-0.01 \\
(0.01)\end{array}$ & $\begin{array}{c}7.61 \\
(1.69)\end{array}$ & $\begin{array}{c}1.08 \\
(0.12)\end{array}$ \\
\hline top-bottom & $\begin{array}{l}-1.16 \\
(0.41)\end{array}$ & $\begin{array}{c}0.72 \\
(1.11)\end{array}$ & $\begin{array}{c}-0.91 \\
(1.41)\end{array}$ & $\begin{array}{c}0.40 \\
(0.58)\end{array}$ & $\begin{array}{c}3.92 \\
(1.42)\end{array}$ & $\begin{array}{c}0.59 \\
(0.70)\end{array}$ & top-bottom & $\begin{array}{c}7.14 \\
(2.28)\end{array}$ & $\begin{array}{c}3.17 \\
(2.12)\end{array}$ & $\begin{array}{c}4.43 \\
(3.64)\end{array}$ & $\begin{array}{c}2.95 \\
(2.14)\end{array}$ & $\begin{array}{c}7.61 \\
(2.27)\end{array}$ & $\begin{array}{c}5.06 \\
(2.41)\end{array}$ \\
\hline
\end{tabular}




\section{Conclusion}

This paper advances a bipartite network representation of the funds-constituents relationships to extract valuable information from mutual funds' portfolio compositions. The topological investigation of the system via network centrality measures helps in identifying not only those funds that diversify the most in terms of portfolio composition, but it is also useful in recognizing either those assets that are present in a huge share of funds or, alternatively, those that are held by few portfolios only. Thus, for a given level of diversification, these measures discriminate between those funds more prone to invest in niche markets and those that opt for common assets.

Our findings point to a negative relationship between funds' extra-performances and the average popularity of the assets held in the portfolios, meaning that those funds investing in less popular assets were more likely to produce positive extra-performances in the period 2003-2010. These more niche investment positions might have been less impacted by fire sales arising due to the financial turmoil that spread after mid-2007, thus limiting negative triggering effects in the markets. The topological information gained from portfolio holdings thus emerges as a complementary source of information that can be combined with past alpha measures to better discriminate among funds.

We propose to exploit the information behind these cross-holdings to built profitable investment strategies that combine both past alpha information, as a signal for persistence in managerial skills, and the topological features of the assets, which mimic actual diversification through more or less popular/common stocks in the market.

From an investor perspective the $A C C$ index can be interpreted as an alternative measure for diversification which takes into account the popularity of the assets across funds' portfolios, offering therefore a competitive view on the actual extent of diversification related to certain portfolio holdings.

\section{Acknowledgments}

Authors acknowledge support from CNR PNR Project "CRISIS Lab". 


\section{References}

Franklin Allen, Ana Babus, and Elena Carletti. Asset commonality, debt maturity and systemic risk. Journal of Financial Economics, 104(3):519-534, 2012.

Aamena Alshamsi, Flávio L Pinheiro, and Cesar A Hidalgo. Optimal diversification strategies in the networks of related products and of related research areas. Nature communications, 9(1):1328, 2018.

Dany Bahar, Ricardo Hausmann, and Cesar A Hidalgo. Neighbors and the evolution of the comparative advantage of nations: Evidence of international knowledge diffusion? Journal of International Economics, 92(1):111-123, 2014.

Bela Balassa. Trade liberalisation and "revealed" comparative advantage. The Manchester School, 33(2):99-123, 1965.

Laurent Barras, Olivier Scaillet, and Russ Wermers. False discoveries in mutual fund performance: Measuring luck in estimated alphas. The Journal of Finance, 65(1): 179-216, 2010.

Paolo Barucca and Fabrizio Lillo. Disentangling bipartite and core-periphery structure in financial networks. Chaos, Solitons \& Fractals, 88:244-253, 2016.

Sebastian Bethke, Monika Gehde-Trapp, and Alexander Kempf. Investor sentiment, flightto-quality, and corporate bond comovement. Journal of Banking \& Finance, 82:112$132,2017$.

Nicolas PB Bollen and Jeffrey A Busse. Short-term persistence in mutual fund performance. The Review of Financial Studies, 18(2):569-597, 2004.

Stephen J Brown and William N Goetzmann. Performance persistence. The Journal of Finance, 50(2):679-698, 1995.

Jeffrey A Busse, Amit Goyal, and Sunil Wahal. Performance and persistence in institutional investment management. The Journal of Finance, 65(2):765-790, 2010. 
Fabio Caccioli, Munik Shrestha, Cristopher Moore, and J Doyne Farmer. Stability analysis of financial contagion due to overlapping portfolios. Journal of Banking \& Finance, 46 : 233-245, 2014.

Mark M Carhart. On persistence in mutual fund performance. The Journal of Finance, $52(1): 57-82,1997$.

Randolph B Cohen, Joshua D Coval, and L'uboš Pástor. Judging fund managers by the company they keep. The Journal of Finance, 60(3):1057-1096, 2005.

Fulvio Corsi, Stefano Marmi, and Fabrizio Lillo. When micro prudence increases macro risk: The destabilizing effects of financial innovation, leverage, and diversification. $O p$ erations Research, 64:1073-1088, 2016.

Joshua D Coval and Tobias J Moskowitz. Home bias at home: Local equity preference in domestic portfolios. The Journal of Finance, 54(6):2045-2073, 1999.

KJ Martijn Cremers and Antti Petajisto. How active is your fund manager? a new measure that predicts performance. The Review of Financial Studies, 22(9):3329-3365, 2009.

Benoît Desmarchelier, Paulo José Regis, and Nimesh Salike. Product space and the development of nations: A model of product diversification. Journal of Economic Behavior \& Organization, 145:34-51, 2018.

Domenico Di Gangi, Fabrizio Lillo, and Davide Pirino. Assessing systemic risk due to fire sales spillover through maximum entropy network reconstruction. Journal of Economic Dynamics and Control, 94:117-141, 2018.

Edwin J Elton, Martin J Gruber, and Christopher R Blake. The persistence of riskadjusted mutual fund performance. Journal of Business, pages 133-157, 1996.

Eugene F Fama and Kenneth R French. Common risk factors in the returns on stocks and bonds. Journal of Financial Economics, 33(1):3-56, 1993.

Eugene F Fama and Kenneth R French. Luck versus skill in the cross-section of mutual fund returns. The Journal of Finance, 65(5):1915-1947, 2010. 
Eugene F Fama and Kenneth R French. A five-factor asset pricing model. Journal of Financial Economics, 116(1):1-22, 2015.

Mark J Flannery and Christopher M James. The effect of interest rate changes on the common stock returns of financial institutions. The Journal of Finance, 39(4):1141$1153,1984$.

Paulo Gala, Jhean Camargo, and Elton Freitas. The economic commission for latin america and the caribbean (eclac) was right: scale-free complex networks and coreperiphery patterns in world trade. Cambridge Journal of Economics, 42(3):633-651, 2017.

William N Goetzmann and Roger G Ibbotson. Do winners repeat? Journal of Portfolio Management, 20(2):9-18, 1994.

R. Greenwood, A. Landier, and D. Thesmar. Vulnerable banks. Journal of Financial Economics, 115:471-485, 2015.

Mark Grinblatt and Sheridan Titman. The persistence of mutual fund performance. The Journal of Finance, 47(5):1977-1984, 1992.

Dominik Hartmann, Miguel R Guevara, Cristian Jara-Figueroa, Manuel Aristarán, and César A Hidalgo. Linking economic complexity, institutions, and income inequality. World Development, 93:75-93, 2017.

Darryll Hendricks, Jayendu Patel, and Richard Zeckhauser. Hot hands in mutual funds: Short-run persistence of relative performance, 1974-1988. The Journal of Finance, 48 (1):93-130, 1993.

César A Hidalgo and Ricardo Hausmann. The building blocks of economic complexity. Proceedings of the national academy of sciences, 106(26):10570-10575, 2009.

César A Hidalgo, Bailey Klinger, A-L Barabási, and Ricardo Hausmann. The product space conditions the development of nations. Science, 317(5837):482-487, 2007. 
Xuqing Huang, Irena Vodenska, Shlomo Havlin, and H Eugene Stanley. Cascading failures in bi-partite graphs: model for systemic risk propagation. Scientific reports, 3:1219, 2013.

Marcin Kacperczyk and Philipp Schnabl. When safe proved risky: Commercial paper during the financial crisis of 2007-2009. Journal of Economic Perspectives, 24(1):29-50, 2010.

Marcin Kacperczyk, Clemens Sialm, and Lu Zheng. On the industry concentration of actively managed equity mutual funds. The Journal of Finance, 60(4):1983-2011, 2005.

Greg Morrison, Sergey V Buldyrev, Michele Imbruno, Omar Alonso Doria Arrieta, Armando Rungi, Massimo Riccaboni, and Fabio Pammolli. On economic complexity and the fitness of nations. Scientific Reports, 7(1):15332, 2017.

Ethan Namvar and Blake Phillips. Commonalities in investment strategy and the determinants of performance in mutual fund mergers. Journal of Banking \& Finance, 37(2): 625-635, 2013.

L’uboš Pástor and Robert F Stambaugh. Mutual fund performance and seemingly unrelated assets. Journal of Financial Economics, 63(3):315-349, 2002.

Christoph G Rösch and Christoph Kaserer. Market liquidity in the financial crisis: The role of liquidity commonality and flight-to-quality. Journal of Banking \& Finance, 37 (7):2284-2302, 2013.

Yonathan Schwarzkopf and J Doyne Farmer. Empirical study of the tails of mutual fund size. Physical Review E, 81(6):066113, 2010.

Andrea Tacchella, Matthieu Cristelli, Guido Caldarelli, Andrea Gabrielli, and Luciano Pietronero. A new metrics for countries' fitness and products' complexity. Scientific reports, 2:723, 2012.

Andrea Tacchella, Matthieu Cristelli, Guido Caldarelli, Andrea Gabrielli, and Luciano Pietronero. Economic complexity: conceptual grounding of a new metrics for global competitiveness. Journal of Economic Dynamics and Control, 37(8):1683-1691, 2013. 
Michele Tumminello, Salvatore Micciche, Fabrizio Lillo, Jyrki Piilo, and Rosario N Mantegna. Statistically validated networks in bipartite complex systems. PloS one, 6(3): e17994, 2011. 